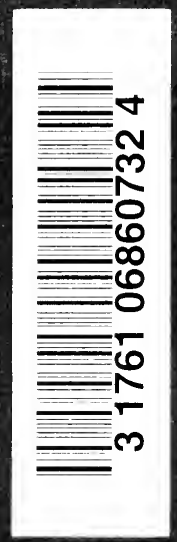


,

$$
\text { -. }
$$



, 
IDEALISM AS A PRACTICAL CREED 
PUBLISHED BY

JAMES MACLEHOSE AND SONS, GLASGOW, Fublishers to the Enibersitp.

MACMILLAN AND CO., LTD., LONDON.

New York, - The Macmillan Co.

Toronto, - - The Macmillan Co. of Canada.

London, . . Simpkin, Hamilton and Co.

Cambridge, - Bowes and Bowes.

Edinburgh,. . Douglas and Foulis.

Sydney, . . Angus and Robertson.

MCMIX. 


\section{IDEALISM AS}

\section{A PRACTICAL CREED}

BEING THE LECTURES ON

PHILOSOPHY AND MODERN LIFE DELIVERED

BEFORE THE UNIVERSITY OF SYDNEY

BY

\section{HENRY JONES}

LL.D., D.Litt.

FELLOW OF THE BRITISH ACADEMY

PROFESSOR OF MORAL, PHILOSOPHY IN THE UNIVERSITY OF GLASGOW

GLASGOW

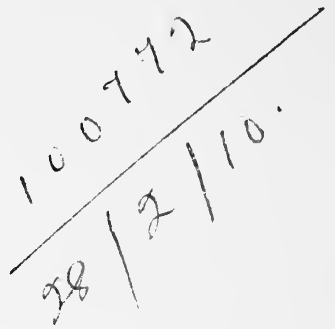

JAMES MACLEHOSE AND SONS

PUBLISHERS TO THE UNIVERSITY

1909 
GLAbGOW : PRINTED AT THE UNIVERSITY PRESS BY ROBERT MACLEHOSE AND CO. LTD. 
To

MY FRIEND

MUNGO W. MACCALLUM

AND

TO THE MEMORY

OF OUR BELOVED MASTER

EDWARD CAIRD 


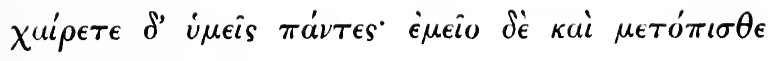
$\mu \nu \eta^{\prime} \sigma \alpha \sigma \theta \epsilon$.

Homer Hymn. Apoll. Del. 166 


\section{PREFACE}

Were it not to take too great a liberty, I should dedicate this book to the Australian people; for my memory of their kindness will not fade, and I would fain let them know that I am grateful. I have dedicated it to one who labours continually for their welfare, and to the memory of a great Idealist-his Teacher and my own.

The book consists of lectures delivered before the University of Sydney. But the written must differ from the spoken word, and I have recast the lectures and added to them.

The University, Glasgow, May, 1909. 



\section{CONTENTS}

I. The Tools and the Task . . . . 1

II. Freedom : First the Blade . . . . . 31

III. Freedom : Then the EAR . . . . 67

IV. Freedom: After that the full Corn .103

V. WORDSWORTH AND BROWNING . . . 139

VI. The Call of the Age . . . . . . 193

VII. The Answer of Idealism . . . . 231 



\section{THE TOOLS AND THE TASK.}

HeaEL's Inaugural Address at Heidelberg: An invitation to the reflective life: Philosophy not always in official garb; its relation to poetry; why taken in these lectures as meaning Idealism.

Man's Life complex because it comprises his World: Connexion of Philosophy and Life illustrated : Hegel and Napoleon the First-which of them means most now: Great men and their times.

Ideas the only agents in man's life: Human history a succession of ruling Ideas: The Idea of Evolution now in power; at work, before Darwin, in poetry and philosophy, and in the world; an exponent of selfexpanding life; which is life attaining Freedom. 



\section{I. \\ THE TOOLS AND THE TASK.}

IN taking up the task with which you have entrusted and honoured me, and inviting you to consider the bearing of philosophy upon modern life, I am reminded of the first words addressed by Hegel to his students in Heidelberg. It was in October of 1816. The Napoleonic wars had just closed with the battle of Waterloo. Germany had risen triumphant from those 'fatal fields, on which her sons were taught a base submission.' She had 'saved her Nationality,' as Hegel said, 'the basis and essence of the best life'; and she could now turn her mind to the arts of peace, and labour to fulfil the higher laws. Philosophy might once more engage the attention and the good-will of men. She might again lift up her voice grown so silent, and 


\section{IDEALISM AS A PRACTICAL CREED}

a world which had become well-nigh deaf to her might again be willing to listen. The spirit of the time immersed in matters temporal, its whole powers engaged in a fearful strife for the outward means of life, might now turn its thoughts inwards upon itself and take possession of the riches of its own content. The Church might now raise its head side by side with the secular State, which hitherto had swallowed up all interests. Side by side with the Kingdom of the World, towards which had streamed the thoughts and strivings of men, the Kingdom of God might become once more an object of contemplation; and along with the political and other interests of the outer life, science, the free rational life of Spirit, might again break out into blossom.

Speaking for those whose lives had matured amidst the storms, Hegel congratulated the students that their youth had fallen at a time when they could devote it to Truth, and the undisturbed pursuit of knowledge. 'I hope,' he said, 'that I may deserve and win your confidence. But I make no claim upon you, save that, before all else, you put your trust 
in knowledge, and in yourselves. The first condition of philosophy is courage towards the truth, faith in the might of mind. Man, because he is mind, may dare, nay, must dare to think himself worthy of what is highest. The greatness and the power of mind he cannot esteem enough. But if he be armed with this faith nothing will prove so hard or stubborn as not to yield itself up to him. The inner being and essence of the Universe, at first hidden and shut up within itself, has no force with which to withstand the courage that will know. It must evolve itself before our eyes, and lay out for our use its treasures and its depths.'

It is not for little men to take upon their lips the language of heroes; yet we can profit by their example and believe in their cause. And it has seemed to me that there is an analogy, not too remote, between your present circumstances as a people, and those of the Prussia of Hegel's day. You, too, have been long engaged in an absorbing struggle with outward and secular things. You have been striving, not without some measure of success, to tame 


\section{IDEALISM AS A PRACTICAL CREED}

a vast continent to your use, and to establish therein an independent and self-sufficient State worthy of that from which you have sprung, gathering yourselves together in these years, amidst many troubles, into a single people, conscious of one political life. If the task has taxed all your strength and claimed all your powers, and if the spirit of your people has been so immersed in it as to leave little of the leisure or the mood for aught else, who can marvel or blame? To live well, man must first live. Nevertheless the order of time is not in all respects the order of causes; and there is a most true sense in which the great things of life must be sought first, and all other things only as addenda and secondary consequences. And I may, perhaps, be permitted to echo the philosopher's hope, that for you, too, the time has come when you can with a more serious intent and a more deliberate purpose devote yourselves to the contemplation of the world within yourselves, the world in which ideals are the only powers. Then you will strive to comprehend and employ more fully, and less wastefully, 


\section{THE TOOLS AND THE TASK}

the greatest of all the energies of the world, namely, those which reside within a people's character.

It is to this contemplation that I venture to invite you in these lectures on Philosophy and Modern Life; and it is in this broad sense that I understand philosophy. I do not conceive it as a technical discipline of the schools, nor as a succession of systems of abstract thought, each in turn professing a rounded completeness and refuted and overturned by the one which follows. Philosophy is an attitude of mind, rather than a doctrine. It is the experience of the world becoming reflective, and endeavouring to comprehend itself. Hence a final philosophic theory is not to be attained, and a fixed system is not to be sought. Experience changes and grows, for it is a process; and a completed doctrine of an evolving process, a static theory of a dynamic reality, must prove false. We can at best but catch its trend and try to discern its greater laws.

This task of self-contemplation and self-comprehension is not one which man can take 


\section{IDEALISM AS A PRACTICAL CREED}

up or let alone as it best pleases himself.

It is a necessity which chooses, and is not chosen. At a certain stage of the evolution of man's rational nature, reflexion arises inevitably. It becomes the urgent condition of further development. The future can be faced only in the light of the past which only reflexion recovers; and the individual, or a nation, can achieve a new triumph only if it has learnt the lessons of its own deeds. Reflexion must succeed action and set free its meaning, if better action is to follow.

We can not be deterred from this reflexion by the fact that our experience is ever wider than our thoughts concerning it; and that, in the end, many of our deeper motives lie hidden and our purposes remain blind. Man is destined by his very greatness to pursue ends he cannot adequately achieve and to ask questions he cannot fully answer. But a little light is better than total darkness. And philosophy, even although she seems, as Kant said, to have failed to strike a sure path, as the natural sciences have done, but 'has kept groping about, and 
groping too, amongst mere ideas,' remains an enterprise which man cannot set aside. If he cannot answer her problems because they exceed his powers, neither can he forego the attempt, for these problems spring from the very nature of his reason.

The despair of philosophy has sprung in part from its own pretensions. It has isolated itself too much : it has distinguished itself too proudly from the ordinary reflexion of thoughtful men. Like Elijah, it has 'been very jealous for the Lord God of hosts,' and borne unheeded testimony in times hard of hearing for the unseen world of mind. But it has exaggerated its loneliness and cried out, ' I, even I only, am left, and they seek my life, to take it away.' It has forgotten the companionship of reflective men who have never worn its garb, and yet have not bowed their knees unto Baal, nor kissed him. Yet these are many. Even in a people like yours to whom the secular interests of the passing day are engrossing, and in whom the pulse of action beats high, as it needs must in a young nation, there are not a few whom 


\section{IDEALISM AS A PRACTICAL CREED}

these interests do not satisfy. They turn their minds inwards and seek to know something of the world of things that are spiritual, in which, after all, is the true dwelling-place of man. 'They are men who convince themselves of the existence of the eternal, of the necessary, of the universal, and who seek to form conceptions which cannot fail them, yea, which are not disturbed, but rather confirmed, by the contemplation of that which passes away.'

Pre-eminent amongst such men-philosophers disturbed and often even repelled by 'philosophy'-are the poets. I admit the difference between philosophy and poetry, and acknowledge that the quarrel of art with the spirit which must dissect before it reconstructs is undying. Yet in the end philosophy is at one with poetry. It sets the apparent in sharper contrast with the real. It wars with the particular, dwells amongst contradictions, it refutes, argues, confutes and demonstrates, as poetry never does, except when it forgets its mission, as sometimes it may. ${ }^{1}$ But their goal is the same,

${ }^{1}$ For instance in the later poems of Browning. 
even though the one reaches it by an inspired flight, while the other must hew its way, and drag its steps. They are one in their deeper purpose, and both are alien, down to the marrow of their being, to the spirit which reduces life into a platitude by emptying it of its ideal meaning. When the man of the world puts 'one passion in the place of another-business, inclinations, amusements, hobbies, and proves them all one after another only to cry out that "all is vanity," ' both poetry and philosophy find his speech 'blasphemous.' The world has for both of them 'a magic value,' for it has been steeped in thought, and they have felt the harmony of its spiritual music. In speaking of philosophy, therefore, I would have you renounce the shibboleths of the schools; and, in order to understand its significance for modern life, learn of everyone who has sought 'the higher nature in nature itself,' or have vindicated the living against the dead and mechanical.

To extend the meaning of our subject in this manner is evidently to despair of treating more than its rim. I shall, therefore, try to limit 


\section{IDEALISM AS A PRACTICAL CREED}

it on another side, and I shall do so in a more arbitrary way. In these lectures I shall dwell, almost exclusively, with that particular form of philosophy which is most in touch with our modern life and most akin to the poetry in which that life has found its best expression. This form goes by the name of Idealism, and, more technically, of 'Objective,' or 'Absolute' Idealism. It is usually identified-in one sense too much and in another too little-with the theory of Hegel: too much, in that this way of looking at life belongs not more to Hegel than it does to Plato or Aristotle, or even to Spinoza; too little, in that our debt to Hegel, the debt of the general mind of our times, is most inadequately recognized.

But, although this limitation of the meaning of 'philosophy' is arbitrary, it is less arbitrary than it seems, and there are better reasons than at first appear for hard dealing with rival theories. In the first place, it is not clear that they exist as living doctrines. Idealism has for a considerable time engaged the reflective thought of Europe, and especially of 
Germany and Great Britain, as no other doctrine has done. The proof is two-fold. On the one hand, those thinkers who reject it are not able to get away from it. They propound no rival theory of their own, but maintain a precarious existence by living on the defects of Idealism, and by indicating-which is not difficult -the problems which it has left unsolved. On the other hand, the principles of this philosophy have entered deeply into the theoretical and practical life of our times. Its main hypotheses are being illustrated and made good in the sciences, especially in those which are biological and human; they are illumined in the greatest modern poetry, from Lessing and Goethe to Wordsworth and Browning; and they circulate in the arteries of our social and political life. There is a certain unanimity of endeavour and community of aspiration amongst the poets, philosophers and reforming spirits of our times: they all make for Idealism. And there is far less discrepancy amongst the conclusions of the philosophers themselves than at first appears; for it is the way of philosophers, as it is of 


\section{IDEALISM AS A PRACTICAL CREED}

theologians and politicians, to make much of their differences.

If, however, I can do little justice to one side of our subject and must narrow down the meaning of 'Philosophy' in this way, I can do still less justice to the 'Modern Life' upon which it bears. Man's life, even when most simple and rudimentary, is the most complex thing in the world. In him the scattered rays of natural existence are gathered together: even as a physical being and mere organism 'he is the consummation of the scheme of things.' And when we turn to his mind, the mind which he $i s$, we find that it is always the counterpart of his whole world. No element or item of the power or the beauty of the world comes to have existence for him at all, except it enter through the portals of his spirit. The scheme of things, the whole furniture of his heaven and earth, the multitudinous objects of his thoughts and purposes, are facts of his experience, the content, nay, the substance of his soul. His world, be it narrow or wide, rich or poor, is focussed in his spirit, and the one measures the other. Its 
reality passes into him as meaning; it is transmuted by his rational nature into sensibility, feeling, thought, volition : and if he thus comprises his world what more need be said to mark his intrinsic complexity? I need not attempt to show how that complexity is further complicated by the reflexion of one man's life into another's, so as to form that most wondrous of all manifestations of the power of man's nature, namely, human society.

These, then, are the two facts whose interaction we have to consider in these lectures.

I may illustrate the connexion of Philosophy with Modern Life by an incident in the history of both. There is a tradition, which is substantially true, that while the guns of Napoleon the First were roaring around Jena, Hegel, the founder of the modern form of Idealism, was seen sitting at the window of his lodgings in that city, writing his Phaenomenology of Spirit -a work which, with Aristotle's Metaphysics, ranks as one of the most adventurous voyages ever made in the world of mind. At that time n less significant business could well be con- 


\section{IDEALISM AS A PRACTICAL CREED}

ceived than that on which this solitary man was silently engaged, amidst the dreadful pudder of the disastrous battle. But it is not easy to decide what is great and what is small in human affairs. If we look back now, from the vantage ground of a new century, we shall justly hesitate before resolving which has meant most for mankind, whether it was the thought of the philosopher or the armed hosts of the devastating conqueror. 'Beware,' says Emerson, 'when the great God lets loose a thinker on this planet. Then all things are at risk. It is as when a conflagration has broken out in a great city, and no man knows what is safe, or where it will end.' 1

I do not mean to suggest that the history of the world has been made either by battles or by books : though there are some books which mean more than most battles. The writing of the Phaenomenology, like the battle of Jena, was only a picturesque moment in a vast movement which had long been preparing. Significance belongs to that which is in the ${ }^{1}$ Crisis. 
context of the world, not to that which stands isolate and singular. No thinker is great and no man is potent in action save by virtue of the might of his times : as no word has meaning, and no musical note or architectural curve has beauty, except in its place. Great men appear in great ages, and they are creatures of what they create. They come in 'the fulness of time,' their messengers sent before their face, into a world which is waiting for them. They are the consequences of vast upheavals, products of the world's stress and strain, pushed upwards from beneath by the pressure of mute social forces which have been long mustering. For this reason great men come, not singly as a rule, but in groups, like highest peaks in a mountainous region. The greatest of them does not stand alone, nor does he rise abruptly from the level plain. His base is on the table-land of some vast public emotion, and around him are companions less in magnitude only than himself. At such a time we behold a whole people

'from the depth

Of shameful imbecility uprisen,

Fresh as the morning star'; 


\section{IDEALISM AS A PRACTICAL CREED}

and find

' in rudest men

Self-sacrifice the firmest; generous love And continence of mind, and sense of right, Uppermost in the midst of fiercest strife.'

Prelude, ix.

All alike, men of thought and men of action, the mighty and the lowly, are at such periods quickened as by some new spiritual force. The earth has circled round as if in its sleep, and a new spring has broken upon mankind. Some new conception shoots forth its rays and enlightens men to larger issues.

This matter is worth looking at for a moment longer ; for, unless I err, we are in the afternoon of such a day, in the power of a conception of which both Hegel and Napoleon, each in his own fashion, were prime exponents. It will help us to understand ourselves, and to realize the magic power of great thoughts. For they have great consequences; nay, they rule the world. Its actions are their offspring.

It is the unique quality of rational beings that, in great things as in small, they act from ideas. Man's impulses are never blind, nor are 
even those desires animal which are most akin to the beast's. Rays of light from the intelligence strike upon them and pierce their texture, and, like clouds, they catch new hues of meaning and of beauty. Through their relation to mind the passions become capable of an excess of evil, as they never are in the brute; and, for the same reason, they are capable of being sanctified to the service of holy causes. Man is always pursuing ends, great or small. It is the idea of that which seems to him desirable, not his mere muscles, or nerves, or bare sense and impulse, which carries him to his every act. Only on that account is he free and responsible; only because the deed was first in his intelligence does he appropriate it to himself and say ' I did it.'

That the root of the idea which brings the act lay in his blind passions, or the dark movements of his impulses, and secret needs of his uncomprehended disposition and organic frame, need not and can not be denied. There is moral as well as merely psychological truth in the saying, that there is nothing in the intellect which was not already in the senses. 


\section{IDEALISM AS A PRACTICAL CREED}

But there is truth also in its converse-that there is nothing in the senses which was not already in the intelligence. The whole truth lies in neither of these sayings; for there is no 'before' and 'after' in the case. No sense or impulse exists in man, bare of all intelligence; and no intelligence which is not suffused with sense. 'Even for the basest sensualist what is sense but the implement of phantasy; the vessel it drinks out of ?' Man is not a machine, nor machine-made, of parts outside of parts. The conflict within him, so-called, of passion with reason, has both passion and reason on both sides. Ends of action, base or high, alternate before his mind, attracting and repelling; and all the ends alike are ideas weighted with impulse and so carry to their mark. And it is this, the presence of the ideal element in every act of man, his pursuit of purposes, mean or noble, which he has set before himself, that distinguishes him abruptly from the brute, and leaves him the promise of being free. If at any time a man urges 'It was my passion, and not I, which did the act,' he has deprived himself of 
the privilege of being human. His excuse is hardly ever true: when it is, his fellows do not hold him to his deeds.

Man picks his way in life. He selects the strands of his purposes from the multitudinous elements of a close-woven world of social and physical environment. $\mathrm{He}$ is free only to the extent of his purposes. Where they are narrow and near, his liberty is limited. But it expands with his comprehension of his world, and is fullest when the better trend and tendencies of his time have passed into his life and become his intelligent will.

These considerations, however, only bring forth anew the power of ideas; for they imply that the master of his time is the man who has understood it; even as it is the man who comprehends the energies of nature who can link them to his purposes. Its powers become his conceptions. There is no break or division whatsoever between the stuff of thought and thought itself, between fact and its meaning.

'Nature is made better by no mean, But nature makes that mean: so, o'er the art Which you say adds to nature, is an art That nature makes.' 


\section{IDEALISM AS A PRACTICAL CREED}

Man finds his true ideas : his making of them is the finding. Every valid invention is also a discovery. The ideas which have power over the world, are the powers of the world; and the poet, philosopher or statesman only sets them free. Hence, when man's history is truly written, written from within, what we shall read is not of the succession of one Royal House to another-of the House of Hanover to the House of Stuart, or of the House of Stuart to the Tudors and Plantagenets: we shall witness, rather, the succession of dynasties of ideas, liberated, set on the throne of the age of which they are the natural rulers, by the great minds which have caught the first glimpse of them. For generations, and sometimes for centuries together, such conceptions direct the thoughts and purposes of the general mind; and they do so with a power so absolute that their presence is often not suspected, for they have insinuated themselves into the very disposition of the men whom they control.

Such absolute, such subtle dominion is exercised by the idea of Evolution in our own 
day. There is no science, from Geology to Theology, which does not contemplate the object of its enquiry in its light. The old static, rigid, cataclysmic way of regarding objects is well-nigh obsolete. We do not consider that we understand anything rightly--nor plant, nor animal, nor man, nor even the fixed strata of the earth's crust, or the planet itself--till we can indicate its place in a process. The whole order of Nature is in movement for modern science. On the level of biology, and thence upwards, it is a grand march, the process onwards of one inexhaustible life, multitudinous in its energy, within which every individual form has its own particular place. Poetry and philosophy, and even theology when it has the courage of its cause, take up the tale of natural science and continue it. They proclaim that the whole scheme of Spirit is also in movement: the psychologist, moralist and sociologist but mark its steps, explaining, or striving to explain, all things by what they were and are about to be. Thus the history of mankind presents itself, through the medium of this conception of 


\section{IDEALISM AS A PRACTICAL CREED}

development, which finds the past in the present and first of all the future, as the gradual unveiling of a purpose which is universal and therefore omnipresent, - a purpose which overcomes the discrete distinctions of time even while maintaining them, and, like the Snake of the Ancients, is coiled around the changing order of the world of reality, and has neither beginning nor end.

In a word, the Idea of Evolution is the lord of all our present thinking-the subtle presupposition which suffuses all our endeavour, whether in the sphere of knowledge or in that of social and moral practice. It is the author of our very temperament, and determines the mental disposition of our times. It has given to the modern age its characteristic ways of action, and unique features, making our era distinct and distinguishable amongst the ages of the world in all its thinking and striving, whether in science or in philosophy, in morals or in politics, in poetry or in religion.

Now, it is customary to attribute the first use of this Idea of Evolution to Charles Darwin. 
In a narrow sense this is just. Darwin was the first to apply it in a great way in one particular field. He did so with such mastering power of observation and scientific imagination as to arrest the attention and compel the belief of the general mind. His success, in his own relatively confined department, facilitated the application of this idea to others, and gave to it concrete form and convincing force.

But the idea was working powerfully in the world before the days of Darwin. To trace it no further-to ignore its use by Aristotle, who is the source of so many of the ideas of modern science-the conception was not only familiar to the poet-philosophers of Germany, to Lessing and Goethe, to Kant and Hegel, to Fichte and Schelling and Schiller, it constituted, one may almost say, the medium through which they observed the world and by which they sought to arrange its phenomena in a rational order. In it, and in the Idealism which it implied for them, in one form or another, was their sole hope of overcoming the dualisms into which the world had fallen, and of breaking down the 


\section{IDEALISM AS A PRACTICAL CREED}

hard contradictions which harassed modern civilization.

But it is vain to seek the first beginnings of a great conception, not less vain than to seek to mark the first beginnings of the blossom of a tree, which is as old as the life that it expresses and adorns. There are no absolute origins in a continuous world. These poets and philosophers themselves found the conception of Evolution to their hand; they only liberated it from the mass of modern history within which it was operative. When they arrived the world was already endeavouring to escape from the harsh contrasts and to break down the intolerable antagonisms of the Middle Age, which had set the next world against this, spirit against nature, the sacred against the secular. Men were already in revolt against a theology which mortified reason, a religion which sought to root out nature, and 'a social state in which men were held down and held asunder by fixed class divisions.' They were seeking enlargement: they would stretch their limbs and breathe freely in a world not all alien and 
unfriendly. Luther had spoken and Cromwell had fought. The banner of liberty had been unfurled, and it had become the symbol of many different rights yet to be made good for the lay and the common man. Instead of the plaintive 'feminine voice of mediaeval piety,' the voice as of a weary pilgrim and sojourner, longing in a vain and unsubstantial world for ' the native land, the patria of the soul,' a manlier cry is heard : 'Here, too, is our Home, for God is here; and the true Shekina is in the soul of man.' 'Nature is not godless, nor is God unnatural.' The natural world is the symbol and vesture of a divine power; and the natural relations of man to man are not vile and bestial, but capable of being smitten through and through with holiness, as a cloud is pierced with light.

Before this period, irreverence had crept into man's worship and blasphemy into his adorations. 'Nature in late centuries,' said Carlyle, 'was irreverently supposed to be dead, an old eight-day clock made many thousand years ago, and still ticking on, but as dead as 


\section{IDEALISM AS A PRACTICAL CREED}

brass, which the Maker at most sat looking at, in a distant, singular, and now plainly indeed, incredible manner. But now, I am happy to observe, she is everywhere asserting herself not to be dead brass at all, but alive and miraculous, celestial-infernal, with an emphasis that will again penetrate the thickest head in the planet by-and-by.' But Idealism cures irreverence, especially the Idealism of Love, which Christianity is. It lifts the lowly, it asserts the rights of the weak, and breaks the power of the strong. From of old the prophets of this creed were revolutionaries. "Those who have turned the world upside down are come hither also.' And their successors in the modern world are engaged in the same task of levelling upwards, "putting down the mighty from their seats, and exalting them of low degree'; dethroning the tyrannic state and the dogmatic church, and setting in their place a Sovereignty whose seat is in the heart of man, a Democracy which would be just, and a Religion which would be free-free to find God everywhere.

In this enterprise the speculations of the 
philosopher, the imaginations of the poet and the tumultuous strivings of the man of action blend together. Hegel, Goethe and Napoleon were all alike, though each in his own degree and manner, products and exponents of that Spirit of Freedom which has been brooding over the chaotic history of the modern world. The idea of Evolution is itself the hypothesis, the methodizing conception which we employ to render intelligible to ourselves the process which Spirit follows in becoming free. It suggests that expansion, that victory of the living thing over its own limits, that conversion of things external which bound and restrain, into elements within its own life, that determination not from without but from within, which Freedom is.

It is our task to explain this movement of the Spirit of Freedom, for this is Modern life; and especially to show how it has been influenced by the Idealism which is itself the effluence and manifestation of that life. 


\section{II.}

\section{FREEDOM : FIRST THE BLADE.}

The Idea of Freedom not simple, except as the seed is simple: The civilization of mankind is the process of evolving its meaning, and the process of life is life itself.

Spirit is free by nature, but things which grow must acquire their nature: The freedom of the individual and of society is at first a blind movement towards an unknown good: Mr. Balfour magnifies "unconscious reason"; why his contrast of tradition and reason is false: Man's life at first assimilative, and the social traditions are the substance of his soul.

Man ceases to be docile and becomes a critic of his social world: The social world loses and the individual conscience gains authority : Man versus the State; why his negative attitude is false: The true Reformer a lover of the ancient ways, and takes their part ag inst themselves; But the world as it is takes the side of its errors and he is forced into opposition; Yet the web of history is not rent, although its tissue is strained : The spread of the controversy between the authority within and the authority without. 


$$
\text { . }
$$




\section{II.}

FREEDOM: FIRST THE BLADE.

THE idea of Freedom, like the idea of Mind or Reason or Will, seems so simple as to need no explication. But this simplicity is all false appearance. These ideas are simple only in the sense in which the seed of a plant is simple: its complexities are hidden, and its powers are asleep; it requires the whole scheme of nature, earth and sea and sky and the revolving seasons, all in one conspiracy, to bring them forth. So it is with Mind, with Will, with the Spirit of Man and its Freedom. What Mind, Will, Spirit are is revealed only by what they can do, and what they can do is made plain only by the expanding movement of human civilization, as it expresses itself in the sciences and arts, the 


\section{IDEALISM AS A PRACTICAL CREED}

commerce and industries, the moral habits, the social usages and the political institutions of man's advancing career. As the chemist brings out the qualities of a gas or liquid, by observing 'its give and take' with other substances, or as the physicist, by his experiments, puts the fact he would understand in new contexts, in order that its latent forces may be set free, so are man's powers made evident-and, indeed, made real also-through his interaction with the world and with his fellows. To change the circumstances of a man is not only to try him, but often enough to exhibit, even to himself, a weakness he did not fear or a capacity whose existence he did not suspect.

Civilization is nothing but the process of revealing and realizing the Nature of Man, and the revelation is still going on, mysteriously and tortuously enough. The intrinsic might of man's will and reason, the slumbering splendours of his spirit are still in process of being liberated. Human nature is capable of a greater variety of kinds than any other 'nature,' and is ever breaking out into new forms; for every 
individual is in his degree unique. No individual, however great, embodies all its possibilities, nor is he at his best when he is singular in his greatness, and his

\section{'towering mind}

O'erlooks its prostrate fellows.'

For only as a member of a society which is worthy of him, 'as the citizen of a good state,' and in interaction with his peers in virtue can man's powers shine forth fully. And a State which is strong in all its fibres, all of whose elements are in harmony, in which no one is ignorant of the best or heedless of the highest -such a State as Hegel called 'The Kingdom of Heaven on Earth '-is, verily, not 'at hand.' Thoughtful men who are lovers of their kind and know something of the toilsome road which civilization has had to travel in order to reach the meagre results they see in the social and political life around them, are appalled by the contrast of what we are and what we might be: so much is yet to learn till our swords are beaten into ploughshares, and man is 


\section{IDEALISM AS A PRACTICAL CREED}

adequate to himself and to the framework in which his life is set.

It is this process of realizing the intrinsic powers of Mind, the process by which Spirit comes into possession of itself and the world, that is, becomes 'Free,' which, in its most prominent features, we have now to contemplate.

There is a sense in which Spirit is always free. $^{1}$ To be free is its essential nature. It is unique in virtue of that fact. But the nature of a thing which grows is the last of all its achievements. It is not the seed but the full grown plant, or, rather, it is the whole process from the lowest stage to the highest which reveals the nature of the life within. It is not the crude savage or the barbarous society, but the wisest men and the countless achievements and varied energies of a civilized nation, or, rather, it is the process from savagery to civilization which reveals the

1 'Spirit' is the best word I know for thought and feeling and will and all the powers of man in interpenetration and indivisible unity. 


\section{FREEDOM : FIRST THE BLADE}

nature of 'Spirit.' 1 Much vain controversy arises from neglecting the fact that it is the process which reveals; and many questions which will remain unanswerable to the end of time are asked: for instance, the question whether the Will of Man is, or is not, free. This question does not admit of a definitive 'Yes' or 'No.' Static categories are all out of place when applied to things in process, which all growing things are. They distort the facts. To do such things justice we require both 'Yes' and 'No.' It is true, in a sense, that the child is the man; but it is also true that he is not the man, and that his sole business, his life through, is to become the man. A developing being is what it can become; and yet it must become what it is. We speak of ' unrealized possibilities,' hardly realizing what contradictions we are dealing in, or knowing what we mean : for we cannot treat possibilities

${ }^{1}$ When a particularly mean or selfish act is done by any one, some men have a way of exclaiming, 'That is human nature.' I should like to protest. Such actions are not typical of human nature. They are distortions and arrestments of human nature. To call them typical is blasphemy against the noblest thing we know. 


\section{IDEALISM AS A PRACTICAL CREED}

either as real, or as unreal, either as actual or as ideal: not as real, because they are only possibilities; not as unreal, because they are possibilities.

Life is placed at the point of intersection of what is and what is not, where actual and ideal meet and mingle, and human life most conspicuously of all; for it is capable of more divergent extremes, and can depart further from itself, than aught else. Man most of all compels us, as we strive to take in the fulness of his meaning, to regard his actual being as potential; for his ideals of a knowledge which is adequate, and of conduct which fulfils his aims and satisfies his spirit, transcend his achievements and are beyond his reach. And yet, these ideals, things that ought to be and are not, are the very deepest realities within him. For are they not the source of all his striving, and the very energy of his enterprise? Man's life is the working of his ideals. His nature is a process. He is not bond or free, rational or irrational; but he is moving from promise to fulfilment, in so far as he is true 
to himself. He is becoming free, and acquiring reason; and it is only because he can become, that we can call him either free or rational.

Now, there is a period in the life of man -and likewise in the history of human society, in the large letters of which man's nature is most clearly read-when it is hard to detect within him even the promise of freedom, so tender is the green blade. We find him sunk in sense, the victim of his immediate wants, the willing, nay, rather, the unconscious, bondsman of powers which he has not recognized. Choice of a kind there always is. He assimilates what he selects. He turns his lips to a good he does not know as the plants turn toward the light, or the child feels for its mother's breast. Nor is it merely sensuous good that he thus blindly seeks; but the rational soul, which he is, also feels for its nutriment. And, doubtless,

\section{' $\mathrm{He}$}

Who fills the mother's breast with innocent milk,

Doth also for our nobler part provide,

Under His great correction and control, As innocent instincts, and as innocent food.' 1

${ }^{1}$ Wordsworth's Prelude. 


\section{IDEALISM AS A PRACTICAL CREED}

But man's choice at first is amongst matters small, although essential; it moves within the narrow range of sensible affections and sensuous needs, amongst alternatives prescribed with his consent unasked and his assent unconscious. It concerns him greatly-does it not?-whether he be born of vicious or of virtuous parents, amidst affluence or utter poverty; whether he enters on the scene of life amongst the Lakedwellers, or in the twentieth century and amongst a people which is civilized. Yet, in these matters he has no choice; and none will deny that they determine the main range and quality of his life.

Born in his own place and time and heir of his parents' strain he is still not free-if freedom means to be emancipate. For, around his spirit there presses continuously an allencompassing spiritual atmosphere. We find him, not in early life only but not infrequently throughout his days, without question on his part or the faintest notion of demurring, saturated with his people's ways of life. 'His language is the language of his people.' His 
opinions and habits, in great things and in small, are the habits and opinions of his neighbours. He has nothing of 'his own.' He has borrowed his tastes, his morals and his creed. The world of traditions and customs into which he is born are assimilated by him as he grows; they enter into his life, become his experience, and constitute the very structure of his soul. He has invented nothing: he has invited nothing: he has but culled from that which was provided. The general life flows around him like the deep sea, and fills the shell of his spirit to overflowing. $\mathrm{He}$ is content to learn and obey, comprehending little of the 'loud prophetic blast' of the vast social harmony in which his own voice feebly mingles. Even when he strives to understand his people's life, and to criticise his times, he does so under conditions which they have determined and with a mind which they themselves have formed. Indeed, they criticise themselves in him. He is their instrument. In him they appear as thinking and willing, and he is mighty only through their presence. Not the 


\section{IDEALISM AS A PRAC'TICAL CREED}

most revolutionary spirit risen in revolt against his age escapes its power, nor can it strike its age except with its weapons. And on the other hand, the best achievement of the wisest men is but to apprehend the meaning of their time and adopt its deeper purposes. Reform is evolution, and prophecy is insight. They are the discovery and the use of the permanent tendencies, a borrowing of the forces of the living world, in order to help the world to overcome itself.

Not more conscious, or less obedient to laws which it does not deliberately choose or understand, is a people as a whole, as it gradually compacts itself into the rational system of the Political State, with its one life and many aims and institutions. A people becomes, and sustains itself as a community, realizing more or less imperfectly a good that is common, without knowing what it is doing. A nation is a 'Complex of Human Forces and Individualities hurled forth, to act and react, on circumstances and on one another; to work out what it is in them to work. The thing 
they will do is known to no man; least of all to themselves. It is the inflammablest immeasurable Fire-work, generating, consuming itself. With what phases, to what extent, with what results it will burn off, Philosophy and Perspicacity conjecture in vain.' ${ }^{1}$ Trackless, in very truth, has been the path of man's history. He has set forth on the greatest of all his quests, namely that of living in a common bond of freedom with his fellows, like the gier-eagle

\section{'Stooping at once}

Into the vast and unexplored abyss, ... strenuously beating

The silent, boundless regions of the sky.'

There is law here also, beyond all doubt. Accident compiles nothing: accident is only a word which men employ when they are ignorant of the cause. But although the law is there and operative it is all unknown to those who follow it: the architect's plan enters not into the thoughts of those who work upon the rising walls of the social fabric. It is

${ }^{1}$ Carlyle, French Rev., Bk. vir. Chap. iv. 


\section{IDEALISM AS A PRACTICAL CREED}

built up in the course of the petty commerce of will with will, as men exchange satisfactions and mutually awaken wants. From the mere need to live, and to be let live, arise slowly the beneficent customs and usages of a common life, a mutual trust and a will towards public justice; and, little by little, they clothe themselves in moral ways of life and stable institutions. Men, at first, as they come together or find themselves together, in early society, have little knowledge of any other good than that of mere living. But

'By the impressive discipline of fear, By pleasure and repeated happiness, So frequently repeated, and by force Of obscure feelings representative Of things forgotten,'

they are led to achieve ends which they have not even desired and to attain forms of good which they do not recognize till they are already in their hands. It was not Saul alone, as it has been well said, 'who went forth to seek his father's asses and found a kingdom.' This is the history of the human race. 
When we contemplate such facts as these, we cannot be surprised that men have magnified 'the unconscious reason of the world,' and found its working within the spirit of man far more excellent than any conscious mind or deliberate purpose of his own. "The only results which reason can claim as hers by an exclusive title are of the nature of logical conclusions,' 1 says Mr. Balfour. And how trifling are these when compared with the all-pervading influences which flow from 'Authority'-which is the name Mr. Balfour gives to tradition.

"If we are to judge with equity between these rival claimants, we must not forget that it is Authority rather than Reason to which, in the main, we owe, not religion only, but ethics and politics; that it is Authority which supplies us with essential elements in the premises of Science; that it is Authority rather than Reason which lays deep the foundations of social life; that it is Authority rather than Reason which cements its superstructure. And though it may seem to savour of paradox, it ${ }^{1}$ Foundations of Belief, 1st edition, p. 212. 


\section{IDEALISM AS A PRACTICAL CREED}

is yet no exaggeration to say, that if we would find the quality in which we most notably excel the brute creation, we should look for it, not so much in our faculty of convincing and being convinced by the exercise of reasoning, as in our capacity for influencing and being influenced through the action of Authority." 1

Narrow, indeed, on his view would be the thoughts, and confused the purposes, of a man who believed nothing and sought no good which he could not justify by means of reason. Reason has a most petty rôle in human affairs. It serves nothing except to receive, arrange, register, and transmit the traditions which are the real substance of man's experience. Reason is a 'formal' faculty - the curator of a museum who catalogues and labels treasures that are not his own. Nor is it matter of regret that its ' $r \delta$ le is petty.' 'Reasoning is a force most apt to divide and disintegrate; and though division and disintegration may often be the necessary preliminaries of social development, still more necessary are the forces which bind ${ }^{1}$ Ibid. pp. 229, 230. 
and stiffen, without which there would be no society to develop.' ${ }^{1}$

We hear the same news of buman reason from another charming writer on philosophy. Our conscious life, for Professor William James, is incomparably less rich in meaning and of less consequence in practice than is the subconscious life upon which it rests. The real forces of our life are out of sight. Our consciousness is a feeble luminary whose light makes a little circle on the surface of an unfathomable ocean with whose heaving we rise and fall, and whose unexplored depths hide the determining passions and the elemental impulses of our being.

Now, there is truth, but there is also mischievous error in these views. Let us try to disentangle them. It is true, as indeed we have already recognized, that what a man is he is in virtue of the traditions of his people. Strip him of all of these and he stands pitifully naked and helpless. For these traditions are not possessions from which he can divest ${ }^{1}$ Ibid. 229. 


\section{IDEALISM AS A PRACTICAL CREED}

or disentangle himself. They are his experience, and a man's experience enters into and becomes the very substance of his rational life. It is operative in all that he does. He can no more set aside his experience when he is distinguishing error from truth, right from wrong, or what has, from what has not, aesthetic value, than he can in manhood exercise the judgment or the tastes of his childhood. The self, at any moment, is not an abstract entity, or core seated at the centre of his experience; it is the organized and living system of his past acts of willing, desiring, knowing, and feeling. For although the acts themselves have passed away one by one, the doing of them has struck inwards in each instance and has modified the self for ever more. The self, in a word, is a living and operative memory: memory which, so far from being the resuscitation of dead or sleeping ideas, is experience repeating itself, the very self iterating its operations.

There is also a sense in which the subconscious life of man is far more rich than his conscious. No effort of reflective thought will 
enable him fully to reconstruct his inner life. He knows himself only in part, as he knows other objects only in part. Nowhere does his plummet reach bottom.

Lastly, I would allow that tradition, which is the experience of his people, is wiser as well as wider than his own. He can appropriate only limited aspects of it. Nay, he is capable of. incompletely exercising his own experience, and thereby of falling below himself. This, as a rule, is what is meant by action from passion. It is to neglect, or to refuse, to put the act in a wide context. Had the young man, tempted to do wrong, asked how his unworthy purpose would affect his life as a whole-his relation to his father or mother, and to the totality of the connexions in which he stands to his fellows, the temptation would have lost its power and relaxed its hold. The power of passion over him is due to his shutting himself in with it, excluding the wide, sane world.

Nevertheless, it does not follow that tradition, wide and intimate as are its content, is in itself better than reason, or has a rightful 


\section{IDEALISM AS A PRACTICAL CREED}

authority to silence its voice. The fact is that the distinction between them is false and their opposition factitious. The tradition of any age is, after all, the product and result of the rational activities of its predecessor. Whence has tradition come? How has it started upon its way? What compacted it at first, and what sustains it? Customs do not arise of themselves, nor do opinions and creeds grow like weeds. Great and powerful as a people's tradition is, it has been built up, like coral islands amidst the deep, from the many little reasons and insignificant purposes of insignificant men. There is no customary opinion which was not once a bold conception, and no habit which was not at one time a venturous enterprise. Reason built tradition, and reason alone receives and transmits it. Brutes have instincts, but not traditions: for though they may be conscious, they are not self-conscious. They can not by reflexion make their own lives an object of their thought, and so enlarge them. The whole rich heritage of the traditions of a people is but as the bank whose wealth is all made up of 
the many savings hoarded by its depositors little by little at a time.

As to the contrast of the wisdom of tradition with that of the individual's reason, whereby the latter is so often rebuked and silenced, that also conceals a fallacy. The comparison is unjust. To make it just we must obviously compare age with age, and individual with individual. Then it will become less certain that the world was wise only at the beginning of things, and that it will be sane only if it refuses to permit the individual to exercise his faculties. To bind reason in chains at the feet of tradition is to enslave it to its own past.

Nor is it reason that disrupts and disin-' tegrates; it is the absence of reason, or its inadequate exercise. A class of boys, set to work a new exercise in arithmetic, will arrive at different conclusions; but let them learn more, and they will agree. They come together in the truth when they reason well. And it is not otherwise with the affairs of life. It is not by darkening the intelligence or by rendering the reasoning powers of man inoperative that 


\section{IDEALISM AS A PRACTICAL CREED}

we can hope to unite a people in the pursuit of the ends which contain their welfare. The vast order of the natural world is being revealed to man, and the sphere of unintelligible chaos is being confined by the combination of the rational enquiries of many disinterested minds, filled with passion for the truth. And the order of society can be comprehended and achieved by no other method. The uncertain, tortuous and most expensive ways in which at present the public welfare is sought is evidence, not of the excessive but of the defective use of reason. We are paying the penalties of the absence of rational research into the principles of social welfare. Our social and political life is the victim of blind experiment, and we find the right way too often only by trying first all the wrong ways and exhausting the possibilities of error; because it is the voice of prejudice and passion which is most audible, and because our statesmen devote themselves to making followers by persuasion, rather than to enquiry. We have no science of social life; and few, indeed, there be who seek it with 


\section{FREEDOM : FIRST THE BLADE}

the sincere disinterestedness of the enquirers into nature's realm.

The tradition of a people has its value; but only when it is taken up and made to live again in the individual's thought and will. The subconscious life of man is rich and great; but he comes into possession of none of its wealth except that which breaks out into his conscious mind and becomes his experience. All the rest of it is like the mystery of the world which lies around him, a territory unexplored, with all its treasures beyond the range of use. For value lies not in things themselves, but in their use and comprehension. Australia, in spite of its vast extent of rich soil and its mountains veined with gold, was a poor continent, of no account in the world's mart, so long as its inhabitants were savage. And the traditions of the wisest ages are a meaningless inheritance to the crude and ignorant. . Of what avail was the art of Greece or the polity of Rome to the Goths and Vandals? Verily, they speak not wisely who would set tradition above or against reason. It is to set the dead 


\section{IDEALISM AS A PRACTICAL CREED}

body above the life which sustains it, protecting it against disintegration and decay.

The truth of the situation thus proves, as usual, to be complex. Tradition and reason are elements which interpenetrate and can not be sundered without being destroyed. The one lives and grows in virtue of the other. If man did not at first accept the beliefs and customs of his people; if he were not for a considerable part of his life docile, assimilative and uncritical of the rational habitudes of his time, receiving his nutriment prepared, simplified and made innocent from the larger life of the social organism, even as a child takes its mother's milk, reason could not be fostered within him. His dependence in this respect is absolute, and knows no limit. On the other hand, there is no doubt that the life of the individual is from the first his very own. At every stage

'Mind keeps her own

\section{Inviolate retirement.'}

Personality is always single, profoundly private and enisled within itself. But it feeds on the outer world, and needs the circumambient air 
of the social sky. What the plenteous produce of the earth is for man's physical organism, the opinions and habits of his people are to his spirit. The mighty energies which uphold the community, maintaining its life unbroken through the centuries, pass into his own life. The substance of his soul is social. He is his social world gathered into a new focus; it is individuated anew in his person. Of freedom, if freedom means separation, there is none, except in promise. The conditions of freedom may be, and indeed are being, slowly gathered together. But the spirit of detachment, criticism and innovation is at first feeble : it is like the revolt of the babe against its mother which brings no cessation of love, or care or nutriment. No society is so conservative as the society which is crude, and no traditions are so inexpugnable, or can live so long after all their meaning has been lost, as those of a savage people. Progress is a force that gathers acceleration as it goes; and in early society it is for ages together quite undiscernible.

But a time surely comes to every man, 


\section{IDEALISM AS A PRACTICAL CREED}

according to his measure, when he ceases to be the docile medium of the traditions of his people. And when he moves he moves society. Absolutely passive he never was; the weakest personality is never mere environment. Pure activity he never becomes, for he never makes all his environment his own, and his experience to the end washes against rocks that bound it. Man, in other words, is never utterly bond or free. But the range of his choice widens and his freedom grows. It is for that purpose that society nurses him on her knees. 'He sucks the breasts of the universal ethos' that he may some day walk about his own ways, and survey the world with the fresh eyes of an intelligence that is awake. Society lends to him her wisdom, imparts to him the rational elements of her own life, in order that by means of them he may scrutinize her opinions, challenge her faith, and reform her ways. Otherwise, her customs would become stale and her faith a lifeless creed. Social life would miss its immortality, which comes, as Plato tells us, only through constant generation. But the 
intimacy of a man and his people is not broken, any more than that of the wise father and his grown-up son,-dutiful in his independence. It is the spirit which has built up the social world that becomes in its own members aware of what it has achieved. By means of their mind, it examines itself and achieves freedom. It can now move onward, not, indeed, shaking off its past, but consecrating it to new purposes and making a stepping-stone of its dead self.

The first result of this change is a certain loss of authority to the social world. It cannot dogmatize any longer, and must exercise its power in another way. Customs, beliefs, rules of conduct, polities, institutions, creeds, which were matters of course, stable as earth and sky and apparently not more subject to man's control, are now seen to be the products of man's activities. Conceived at first to have come from the Gods-for it is to the Gods that every people, Jew and Gentile, Greek and barbarian, attribute the first institution of their laws-they are found to have originated in the warring passions and the groping reason of 


\section{IDEALISM AS A PRACTICAL CREED}

men. They are inventions, conventions, devices which men have hit upon from time to time and agreed about in order to live, and to live more abundantly. Men have been brought together into communities by their wants, and they are held together by their mutual use. Utility has built the State and utility may pull it down again; for when the spirit of man becomes aware of its own might, it will assert its own rights. What it has created it may also destroy, if it pleases; for the worker is ever greater than his work.

Thus, there gradually grows up an inner world of personal conviction and of private rights. The individual constitutes himself into the measure of all things, and the arbiter of all values. The standard of truth and error is his own judgment, and of right and wrong is his own conscience.

At certain periods, and by certain individuals, as in Athens and by the Sophists, this world of inner conviction is set against the outer order of objective law and custom. The authority of the State is set at nought. This is the prize and 
the penalty, the first bitter fruit of reflexion, of that turning of the mind inward upon itself, which philosophy is. In all ages of the world the young philosopher, as Plato tells us, is like the puppy-dog. He must tear things to pieces while he is teething. There are men always, on the way to wisdom and not yet arrived, in whose ears, let the State and Church say what they will, there is an inner voice which keeps murmuring, which they think is all their own. They will adopt no belief except that which approves itself to them as true; they will obey no law which they do not think just; they will lend themselves to no purpose which they do not themselves approve; and they have no misgivings, for the world has shrunk into the measure of their thoughts, and they know not that their minds circle within a larger system.

At such periods men make much of their 'Freedom,' and they construe Freedom as Independence. Their attitude towards the social world is negative. They will hold all its influences at arm's length. They desire none 


\section{IDEALISM AS A PRACTICAL CREED}

of them. They want to be let alone to follow the guidance of the inner light. Not only is that light deemed all-sufficient; it is taken to be original and inborn. There are no moons amongst minds in these periods; all are stars, self-poised and self-illumined. The tendencies at work in human society at such times are comparable to those we find in a family of grown-up sons and daughters. There is a trend towards disintegration, which may, if powerful enough, leave the parents desolate on a hearth grown strangely silent. The State decays with inward feebleness and sinks within itself, turning, like old age, from action to reflexion, and idly feeding itself on the memory of past nobleness. A form of civilization, as was the case in Greece, passes away to return no more. And it is well if, as was again the case with Greece and Israel, it leaves a record of its experiences in a literature, from which the newer world, patient of the past once more, may strive to learn.

When judgment is passed upon such periods as these it is all too apt to be abstract: one 
critic sees naught but anarchy, another naught but liberty. There is in truth neither because there are both mutually modified. As usual the error lies in not observing the positive beneath the negative, the permanent truth within the passing falsehood. The agents of this new spirit of freedom, which is interpreted as independence, stray from the paths of wisdom and of truth not in what they assert but in what they deny. They do well in setting a high price on private judgment and in assigning to inner conscience an authority which is supreme. But, in the last resort, private judgment and the moral voice within are worthy to be prized, not because they are private, but because they stand as spokesmen and plenipotentiaries of a Good that is wider than is embodied in the objective order of the State against which they are in revolt.

This truth is seen by the wiser spirits. It was seen by Socrates but not by the Sophists, by Burke but not by Bentham. The former knew that 'men would never look forward to posterity who did not look backward to their 


\section{IDEALISM AS A PRACTICAL CREED}

ancestors,' and that they cannot serve the world except by borrowing its powers. To the latter the wisdom of our ancestors was 'the infantile foolishness of the cradle of the race.' Such contemners of the past would shut out the experience of the world, not knowing that in doing so they would shut in their souls on emptiness. Their criticism appears to them to emanate solely from within themselves, and they are not aware that they have got their objections to society within society, and that no man can rise above his age except by means of it.

The successful founder of a new régime has always been the devotee of the old. He has been a more ardent disciple and a deeper lover of the ancient ways than others. He makes the hearts of his followers to burn within them because he can open the ancient scriptures of his people. $\mathrm{He}$ has come not to destroy, but to fulfil. He brings to light the better meaning of the ancient faith, and by evolving the present from the past sets free the future. He gives articulate voice to the 
dim yearnings of his people, and liberates the ideals surging darkly in their heart.

The true reformer is always a generous spirit. So far from feeding on the errors of his time, or condemning its institutions, he takes their part against their lower selves and declares war only against their corruption. No great reformation either in politics or in religion has ever arisen from the spirit of negation : negation is only an accident and bye-product. The true reformer of either Church or State does not aim at overturning them, and it is not his desire to establish others in their place. He would relieve the Church of encrusted falsehoods, he would deliver his country from the wrongs which it inflicts upon itself. He battles for the ideal which is already in the world, and against the accidental forms which cramp it. $\mathrm{He}$ is not less but more loyal than his fellows; and he chastises because he loves.

Hence it is always against his will that he finds himself in opposition to the constituted authorities. He is forced into it; for the error which he attacks is not recognized as an 


\section{IDEALISM AS A PRACTICAL CREED}

error by others, and they come up to its support. Moreover, all errors are partial truths, and all social wrongs are entangled with the right, and part of the fabric of the general customs. The ancient ways of a people die hard, and their soul is not easily released from the forms in which it has embodied itself. The State and the Church resist reforms, and the world as it is takes the side of its errors, not because it prefers falsehood to truth, or right to wrong, but because the error and the wrongs are part of their structure. They cannot be removed, as the reformer generally finds, without endangering the whole edifice. This is why there falls upon him the hardest fate of all, namely, his estrangement from good men. Hence also the world is at all times apt to crucify its saviours, not knowing what it doth. For it is in their loyalty to the good which is visible in the world that in one age they slay their prophets- 'the seers' of the good not yet come-and build their sepulchres in the next.

Thus, in the last resort, the web of human 
history shews no rent; its deepest changes, as indeed must be, are changes of the permanent. Nor is such a dissolution of continuity the condition of freedom. It does not bring independence even, but much helplessness. 'Man lives not except with formulas, with customs, ways of doing and living. Ubi homines sunt modi sunt. There are modes wherever there are men. It is the deepest law of human nature, whereby man is a craftsman and toolusing animal ; not the slave of Impulse, Chance, and brute Nature, but in some measure their lord.' 1

Nevertheless the change which ensues during the conflict of the hero and his age often strains the social tissue to the uttermost. The controversy spreads far beyond any particular question of right which happens to be in dispute between the hero-be he prophet, priest, or statesman-and his times. At certain periods, when what we have called the stage of negative freedom, or 'Independence' is first reached, the universal issue is raised of the relation of the ${ }^{1}$ Carlyle's French Rev., III. ii. 1. 


\section{IDEALISM AS A PRACTICAL CREED}

individual to the outer powers. Shall he obey them, or they him? Where is the final authority: is it within or without? Does it lie in the inner order of the individual conscience, or in the outer order of the Church and State? Has the individual at any time the right to challenge and overturn the social order? Has the State at all times the right to overrule the action of its members, and can it at any time invade the territory of their inner life? Or has each of them a particular province within which it may rule supreme? If so, who shall fix the boundaries, or say to its rival, 'Thus far thou comest, and not further?'

When this question has been fairly raised the banner of freedom is in very fact unfurled. Men slowly rank themselves around it, nation by nation, age by age, and strive to make their footing good against all despotic and alien powers, whether they be the powers of Nature or the State,-or even of ' a divinity not themselves'-making for righteousness.

It is to this controversy that we must turn in our next lecture. 


\section{III.}

\section{FREEDOM: THEN THE EAR.}

The Eastern peoples have no genius for Statecraft: The Greeks discover the Free State: The Greek State a product of the Imagination; its characteristics; a social paradise : Reflective thought is born, and destroys the product of the Imagination: The Greek Sophists: Socrates exercised a stronger destructive power than all the Sophists; for he endowed the individual conscience with universal rights: The growth of the spirit of freedom, shatters its outward forms; the old institutions perish and humanity is launched on a new enterprise: Both the inner aud the outer law are absolute: Their conflict; its phases exhibited in Stoicism and Christianity, in Roman Catholicism and in Protestantism : Why freedom comes tardily and must take mauy forms : Emancipation is negative and only the alphabet of true freedom: It reached its full expression in the French Revolution: The preference of Aaron to Moses: Napoleon and Demoiselle Chaumette: No leaps in moral and political wisdom; and reconstruction must begin at the bottom and run up the whole scale: The new freedom restores the ancient world but reinterprets it: The prophets of the New Age and its practical business. 


\section{III.}

FREEDOM: THEN THE EAR.

IT is generally recognized, I believe, that only the Western World has shewn any genius for statecraft or any strong impulse towards political freedom. In the East, says Hegel, we find 'despotisms developed in magnificent proportions': sovereign lords to whose will there was no limit, save their own caprice or superstition, ruling over peoples who were conscious of no political rights. Only one man was 'free.' He had rights and no duties, while his subjects had the one all-inclusive duty of absolute obedience. Even in the history of Israel, to which modern civilization is in some respects most indebted of all, we find little promise of free institutions, and no conception of government except that which 


\section{IDEALISM AS A PRACTICAL CREED}

was rooted in the will of a despotic God, priest, or king. Nor is it otherwise to-day amongst the vast and varied populations of India. The supreme obstacle, which threatens to frustrate the British people in attempting to educate them into self-government, lies in the fact that they can hardly be taught to rule except as despots, or to obey except as slaves. Modern history presents no more interesting spectacle, or more doubtful enterprise, than this of inoculating these Eastern peoples with the spirit of the West.

The first experiment in political freedom was made in Greece ; and amongst all the discoveries of that wonderful people there was none so great as the discovery of the idea of a State, founded upon the freedom of its members. None certainly has brought a greater array of beneficent consequences in its train. It was in virtue of it that they broke the brooding quiet of a world stagnated, and introduced into it, for the first time according to Sir Henry Maine, the very idea of progress.

How to account for their discovery we do 
not know. Hegel suggests that it sprang from the temper of the people, which was like that of the artist, - ' a free individuality, conditioned by beauty.' But, of course, when one speaks thus of the 'temper or disposition' of a people, all that is meant is that we lose sight of the determining cause amongst a complex totality of elements. These terms are merely limiting conceptions, and a confession of ignorance. Free, spontaneous, joyous, the Greeks certainly were; and they were creatively impelled, as artists are, to impress their own imaginative conceptions upon outward things. Imagination is essentially free, and a ruling lord in its own domain : it always finds its material plastic, and saturates it with itself. Hence, while the spirit of the East was submerged in nature, and individuality was overwhelmed, the Greeks looked at the world with the frank and fearless eyes of youth. They were neither Nature-worshippers nor Pantheists. They peopled Olympus with fair humanities, and kept Destiny in the background. Their religion was as the sunlight. Their Gods were 'ideal figures, fixed like 


\section{IDEALISM AS A PRACTICAL CREED}

statues in the eternal repose of beauty,' and they mingled freely in the affairs of men.

For the same reason the Greek State was just 'the individual writ large.' It was not an awesome and alien entity, or abstract power, elevated above the citizen and endowed with mysterious authority, in whose face he dared not look. He saw in it only the replica of himself. Originally the Greek State was so intimately at one with the citizens themselves that in seeking its good they never conceived that they were serving a foreign power. Indeed, at this stage neither their moral nor their political ends came before them as duties. The Greeks, says Hegel, 'had no conscience.' They had fine impulses. T'hey served their country without reflexion, with the same spontaneous naturalness with which they served themselves. 'Their object was their country in its living and real aspect-this actual Athens, this Sparta, these Temples, these Altars, this form of social life, this union of fellow-citizens, these manners and customs. To the Greek his country was a necessary of life, without which existence 
was impossible.' In short, if their politics were not moralized, after the manner of the best periods in our own history, their morals were socialized to a degree which we have not as yet rivalled.

No conditions could be more favourable to the birth of political freedom than those furnished by the imaginative spirit of the Greeks. Nevertheless, this first experiment in freedom was timid in character, limited in scale, and of short duration. The Greek State was small in extent: it was only a free city. Its citizens were few, and the slaves were many. Its basis was so narrow, and its members so volatile, that it was constantly in danger of toppling over into despotism. The very sentiment of equality rendered it insecure. If from time to time the people 'placed their confidence in men of plastic genius, calling a Solon or Lycurgus to legislate for them, or placing a Miltiades, Themistocles, Aristides, or Pericles at the head of their affairs, as soon as any of these great men had performed what

${ }^{1}$ Hegel's Philosophy of History. 


\section{IDEALISM AS A PRACTICAL CREED}

was needed, envy intruded-i.e. the recoil of the sentiment of equality against conspicuous talent-and he was either imprisoned or exiled.' 1

The Greek State, in fact, was the supreme instance of enlightened comradeship. Every one was free and equal to his neighbour; and the question of rights was not raised. For the most part they lived together in the city, and saw each other daily. In times of danger they could all take refuge within its walls. Moreover, any citizen could hold any office. ' $\mathrm{He}$ must be present at the critical stages of public business; he must take part in decisive crises with his entire personality-not with his vote merely ; he must mingle in the heat of actionthe passion and the interest of the whole man being absorbed in the affair.' ${ }^{2}$

A fairer state than the Greek State at its best, as it was in Athens at the time of Pericles, has never been seen amongst mankind. But it is evident that it was not capable of expansion. Least of all could it exhibit the full implications

$$
{ }^{1} \text { Ibid. } \quad{ }^{2} \text { Ibid. }
$$


of freedom. It was like a paradise to which man will always look back with longing, but which he must leave as soon as the quarrel between nature and spirit breaks out, and right is distinguished from wrong.

And herein lies the second supremely interesting aspect of the Greek State, namely, that it did lose the paradisaical form which it possessed as a product of imagination and as the expression of the innocence of natural impulse. The Greek spirit, as I have already hinted in a previous lecture, looking at all things with frank and fearless eyes, became in due course aware of its own activity. It found itself to be supreme. Mind was the ordering power in the world; and in man himself was hidden the solution of the enigma of being. To 'know himself,' therefore, was his first duty. Thought turned inwards upon itself, became reflective; consciousness emerged as self-consciousness, impulse and instinct as deliberate purpose and will.

Now, reflective or self-conscious thought is at first inimical to the imagination. It hobbles its spontaneity with criticism and brings hesita- 


\section{IDEALISM AS A PRACTICAL CREED}

tion in place of confidence; it substitutes analysis for synthetic construction, and abstractions for sensible concrete products. Above all it introduces for the first time a contrast between the true and false, the right and the wrong, the permanent reality and the passing show: contrasts with which the imagination has nothing to do. Who cares whether Cordelia or Imogen ever lived, or whether a painting is or is not a portrait? A work of art has its own truth, but it has nothing to do with the context of the wider world: it is enough if it be fair, standing out justified by its own beauty. ${ }^{1}$ You cannot universalize a work of art; the sensuous element, which is always particular, is as essential to it as the idea which lives and breathes, half-revealed and half-concealed, within it.

When reflexion was set loose upon the political state of Greece, and the rectitude of its claims and foundations of its authority over its members came to be investigated, it was doomed. Founded on impulse, it could not stand the

1'The artistically true and the naturally true are entirely distinct,' says Goethe. 
strain of thought. Hence the ethical enquiries of Socrates were fatal to the Greek State, more fatal even than those of the Sophists. It is true that the Sophists had found 'Man to be the measure of all things,' and his rights to be unlimited. But though the will that would destroy the outer order was in their teaching, the power was not. For the individual whom they set against the State had no better content than caprice. He might think what he pleased and will what he pleased, and anything he pleased would be true and right for him. But for the same reason they might be false and wrong to his neighbour. Each man's domain terminated within himself, and there was nothing at his back to sustain him. But it was otherwise with Socrates. He had the same conviction as the Sophists of the primacy of individuality, but he had a far deeper intuition of its significance. For him the rights of individuality lay, not in its singularity or caprice, but in its universal nature. Mind, or Spirit, had the intrinsic capacity for deciding questions of right and wrong, truth and falsehood, in a way that was 


\section{IDEALISM AS A PRACTICAL CREED}

final, because it was valid for all. Socrates strove to bring his fellow-citizens to recognize, not only that Virtue is knowledge, and that every man must know the right in order to do it; but also that Virtue has a universal character. It implies knowledge of a Good which was good in itself, supreme, lifted above the power of the individual to challenge or change.

Here then there is brought to light, for the first time, the sovereign nature of conscience. It was not only an authority which claimed, but it had the right to claim, precedence over every other authority-be it use and wont, or a political law and institution. Socrates was condemned to death as the enemy of the State, and the sentence, says Hegel, 'bears the aspect of unimpeachable rectitude.' The Greek State was not put together on principles that could sustain the stress, or give room for the play of individualities which were so ample and so fortified in their claims of freedom. Its loyalties were too narrow, its duties too confined, and its privileges too exclusive. The State could pre- 
scribe loyalty only to Athens, or only to Sparta, or, at the widest, only to the Greeks-never to the barbarian, or to man as man. There were also slaves within it, and slavery was essential to it. Hence, the teachings of Socrates were fatal to the Greek State. The spirit of freedom, growing apace, shattered the political form in which it was confined; 'as an oak-plant shatters a flower pot.' It had, thereafter, to find, or rather to form, an outward political order more adequate to itself; and mankind is launched on a new and vast enterprise, namely, that of reconciling absolute inner freedom with the absolute rule of objective law.

This transition from sense to thought, and from impulse to conscious will, or rather this sublimation by internal evolution of the former into the latter, is the most momentous step in the history of man's spirit. It is not abrupt: it is prepared for. It is the result of a slow ripening, that is of constant decay and re-birth, in which something is always passing away and something new, rooted in the old, is always appearing. Its stages are so gradual that they 


\section{IDEALISM AS A PRACTICAL CREED}

can hardly be discerned. And yet there takes place a momentous revolution, or a series of revolutions. One day there is the blind bud, the next the open blossom, the next the fruit -each a surprise.

When sensuous knowledge and impulse blossom into self-conscious thought and purpose, man comes of age, and is ruler in his own house. $\mathrm{He}$ is manifestly endowed with a new privilege, and the privilege is the first thing of which he is conscious. But he is also laden with a new responsibility. He has the duty, as well as the right of private judgment; the peril as well as the privilege of being free. And in the last resort, the privilege and the right will be maintained only if he can rise to the height of the duty. The right of private judgment is after all only the right of passing a judgment which is just; and the right to be free is not the right to be capricious. It is the right to will in accord with the will of the whole, and therefore to find the nature of things to be, not an obstruction, but a power on its side. For this alone is freedom. 
Freedom has thus two aspects, both of them of infinite value and, in the last resort, incapable of any limitation or compromise. Both the inner and the outer law must be supreme. The voice of conscience and the voice of God are both authoritative, and they must be in agreement. The law of rational life must be self-imposed, and yet its imperatives must be categorical.

Human history is the arena wherein these two powers come together, now in conflict, now in agreement, now in new conflict, and in new agreement. The peace of the natural life having been broken, and the political unions in which it first manifested itself having been destroyedthe civic States of Greece and the sublime theocracy of Israel having proved incapable of standing the strain of the universal truth that was working within them, a truth which concerned the destiny of all mankind-we find the Imperialism of Rome erected on their ruins. This was a monster State which had no bowels of compassion for the minor loyalties of national life, but with a proud indifference it destroyed 


\section{IDEALISM AS A PRACTICAL CREED}

all which it did not ignore. It was just, but not merciful, extending its power above the nations like a steel sky. It was an abstraction in which the heart of man could not delight, and which was deaf to his prayers. Moreover it became corrupt, and faith in the objective order died within man. He must seek refuge elsewhere : in himself, said Stoicism; in a city beyond the skies, said Christianity. Both of them, each in its own way, sought to wean man from the world, for it was an empty appearance to the indifference of the one, and to the other a place all alien, in which men with an eternal mission in their hearts were pilgrims and sojourners. Christianity joined its unresisting meekness and the virtues of resignation to the enduring pride of Stoicism, and, with nothing revolutionary in its aims, it sapped the strength of the imperial institutions. Only at such a cost could 'the Kingdom of Heaven' be built within, and the spirit of man be set free to walk in the rays of its own light.

But it is an error to regard this movement as purely negative. Man cannot live amongst 
negations. Every new step which was gained in freedom, every new truth which came to be recognized, could be made valid only if it embodied itself in an external form. The ideals of man must have habitations in which to dwell, else they lapse back into empty aspirations and disappear like smoke in air. 'The word must be made flesh.' Ideas must become practice, use and wont, stable laws and institutions. A visible Church had to grow, and it had to build its own institutions in the world and hold some commerce with it. Ultimately it had to conquer the Empire, and to risk its own spiritual life in the process, becoming itself a secular power, wielding secular weapons, and oppressing the Spirit of man once more. Negative forces had to come into play again : for Protestantism was at first a 'protest,' however we may regard its later history and its future.

Thus do we find two laws always operative. In the first place, inner and outer freedom grow together; for the former must always express itself in the latter. In the second place, the spirit of freedom as it grows must 


\section{IDEALISM AS A PRACTICAL CREED}

set up new obstructions to its own progress. The spirit is living, an activity that does not rest, a process which does not stop; but it must take forms that are fixed. It must express itself in habits, in laws and institutions,-vestments which must grow old and be cast off again; for 'good customs corrupt the world' in becoming customs.

It is no marvel, therefore, that the march towards freedom has been slow, or that the footprints of man's history are stained with blood. Nothing else can be expected from his intrinsic nature. "The first man is of the earth, earthy,' steeped in sense, and impulse is his only law. But he is meant to wear on his brow the crown of spirit; to reign as king over his own impulses and to subject the world to obedience. To the natural man, the crown of spirit is, indeed, a crown of thorns, worn on the way to death. If he has not to destroy his natural impulses by ascetic ways of life, he has to convert them into vehicles and instruments of purposes which are spiritual-which is still more difficult. If he 
has not to abandon the beneficent usages of a life within society, he has to transmute their meaning by referring them to an inner law, and to lift them into duties. If he still follows paths worn easy for his feet by the multitudes which have gone before, remaining a loyal citizen amongst his people, he must also venture the untried. For the moral life is all a lonely enterprise, and there is no light upon the way, except that which shines from the inner law of dutifulness and reverence for the right.

When we turn from the individual to the State we see the same spectacle of a freedom which comes tardily and with infinite toil. It is demanded within the State at first only by the few, in regard to a few matters, and in a small degree; and these few find all their world ranged against them. If the consciousness of the Might of Spirit and of the inevitableness of its victory leads the hero, in an inspired moment, to proclaim that 'he has overcome the world,' he is aware at the same time that his victory is gained only in principle. The 


\section{IDEALISM AS A PRACTICAL CREED}

'whole mass' has yet to be leavened. The new principle has to become first the aspiration and then the habit of the many; and men are sluggish, and the sleep of sense is deep.

Further, freedom has in the long run to take many forms, and to master many kinds of resistance. It must be religious freedom, as well as moral freedom. And to this end, knowledge must oust superstition, love must cast out fear, the bondsman must become a Son, and God a Father. Man must claim to hold immediate converse with his God, the finite with the infinite: his God shall grant it; and man, seeing God face to face, shall find, not death, but life.

It must also be social and political freedom : a form of government and a mode of life in which a whole people seeks a common good, which is alone a true Democracy. For Democracy is much more than a claim to rule on the part of all the people. It is the consciousness of the obligation and the privilege of service. It is 'a Kingdom of ends,' to use the great phrase of Kant, 'in which all are sovereigns 
and all are subjects' - a form of public life not clearly conceived as yet, far less attained by any community.

Such freedom as this-the freedom of perfect service-has hardly become the conscious purpose of any modern State so far. Our most generous political impulses, so far, have too often as their aim the freedom which is Emancipation, and which is only the alphabet of true liberty. The spirit of our most revolutionary socialism is, as a matter of fact, deeply tainted with the selfishness of Individualism. The aspiration is still to endow individuals with the right and the power to hold their own. Nor is this wrong. Has not the lowest life the task of maintaining itself against the whole environing world, and of preventing forces which are foreign from invading the sanctuary of its inner being? Negation, resistance against, and the exclusion of, all that is alien, is a necessary condition of the humblest individuality. Without this self-assertion and repulsion, nothing could live its own life. But these forces reach their crisis in the life of Spirit. Mind ruthlessly excludes, 


\section{IDEALISM AS A PRACTICAL CREED}

nay reduces into meaninglessness and nonentity, all that refuses to bend to its yoke. What Spirit does not know or purpose is as good as nothing for it: things come to be for it in acquiring meaning.

But the freedom, which is merely freedom from the world is, we say, only a preliminary stage of true liberty. The man who makes most of his detached and irresponsible personality is not free, but capricious. $\mathrm{He}$ is unjust to himself, for the capricious spirit is the least rational; his pure independence is utter weakness, and he is ungrateful to the world. The objective order, physical and social, against whose necessities he is in revolt, and from which he desires to be free, is the world which has nourished him. The laws and institutions he would overthrow, the State which he would overturn,-or, what is worse and more common amongst both classes and masses, ruthlessly use as mere means of private ends, - have been to him a shelter and a refuge. But in their ardour for emancipation and the energy of the assertion of their Individuality men do 
not remember this. The Church may have fostered learning, cherished the virtues, shed the light of eternity on the things of time; the State may have founded freedom, instituted and protected every right of person and property that the individual can claim or seek to enhance -all this is forgotten. When the Spirit of Individualism is abroad the stable strength and the unobtrusive benevolence of the ancient authorities seem to be in the way, a standing obstacle to the one thing which is now desired, namely freedom. The cry at such periods is for Emancipation. The motto is 'Let me be,' 'Laissez faire; laissez aller.' The old ties and loyalties have become irksome bonds. The demos wishes to have its limbs free, to walk if it can, unfettered by conventions. It will have its own way, and follow its own thoughts, at any cost and in any manner it pleases. It will express its new-born liberty in literature and all the arts in a romantic exuberance of forms. It will make its own experiments in politics and even in religion: resolved to march, though it knows not whither. It prizes doubt above 


\section{IDEALISM AS A PRACTICAL CREED}

the creeds outworn, and will prefer Scepticism to the ancient faith, and Nihilism to the ancient régime. It will live 'according to nature,' which always means living according to the impulse which happens to be most in evidence at the moment. It prefers to go naked rather than to wear the decent habiliments of custom, and the only vice it recognizes is ' respectability.'

It is usual, and I think right, to say that this kind of freedom obtained its boldest and most unrestrained expression in the French Revolution. The Gospel of Jean Jacques Rousseau was then fairly taken to heart. This people would dissolve the old conventions, and, if they could not do without any at all, if they could not 'go back to nature' without 'going on all fours,' they would at least submit to no conventions except those which were forged by themselves by universal consent, and these should be as few and as light to bear as possible. If the State must 'interfere' it shall not interfere much.

Negation could hardly go further than it went in those days. 'Old garnitures and social 
vestures drop off, being quite decayed, and are trodden under the National dance. ... The Nation is for the present, figuratively speaking, naked: it has no rule or vesture; but is naked -a Sanscullotic Nation.' ${ }^{1}$ Tradition, secular and sacred, was set aside; history was repudiated, for it was 'The Year One.' There was social anarchy and religious scepticism : anarchy not merely as revolt against the evils of the government which had just perished, but as a spirit of individualism which regards any government as a restraint; and atheism, not merely in the sense of denying the deistic deity of that time which was only an idol, a God remote and without ears to hear or hands to help, but in the far deeper and more disastrous sense of secularizing the spirit of man and reducing it into a thing with senses, plus unlimited greed.

And yet there was more at work than nihilism and atheism. Negation is never mere negation. Men deny one thing because they believe something else with which it is inconsistent.

$$
{ }^{1} \text { Fr. Rev. III. ii. }
$$




\section{IDEALISM AS A PRACTICAL CREED}

Negation is the collision of two positives: it is one segment of experience saying ' No' to another segment: it is often the faith of the present generation at war with the faith of its predecessor. In this case it was the faith of man in himself set against the authorities, human and divine, which had been ruling him without consulting him.

It is because negation is the collision of two positives, an experience divided against itself, that no rest can be found in it. The situation is intolerable. No house can stand if it be divided against itself; that of spirit least of all. Experience has a varied content, and it often entertains contradictions, but not willingly, if they are awake and vocal.

Hence scepticism, whether religious, moral or social, is always in unstable equilibrium. If the old faith has become impossible a new one must be found. At the very heart of the wild anarchy of the French Revolution there was a striving for some opinion that men might hold by, for some way of life that might be worth following, for some social order within which 
they could find refuge. There was a hurried obedience to the inner imperative which compels the spirit that negates to escape from its own achievement.

It is no marvel, therefore, that this people should at first build its new social and religious edifices with slack mortar: that their 'constitutions would not march.' Is it not a rule of old that when men put aside the sober raiment of the ancient morals, they will clothe themselves in the tinselled tags of caprice? I have never known a sceptic who had not his superstitions. People who reject both Christianity and Science adopt Christian-Science; and if they do not trust in God, it is as likely as not that they will believe in ghosts. When the Israelites lost sight of Moses they gathered themselves unto Aaron; and he took their offerings and 'with a graving tool fashioned them unto a molten calf; and they said, These be thy gods, $O$ Israel.' 1 And there was a day in the history of the French Revolution 'when Procureur Chaumette and Municipals and Departmentals

${ }^{1}$ Ex. xxxii. 4. 


\section{IDEALISM AS A PRACTICAL CREED}

arrive, and with them the strangest freightage: a new Religion. Demoiselle Candeille, of the opera; a woman fair to look on when well rouged; she, borne on palanquin shoulder-high; with red woollen nightcap; in azure mantle; garlanded with oak; holding in her hand the Pike of the Jupiter-peuple, sails in; heralded by white young women girt in tricolor. This is our new Divinity: Goddess of Reason, and alone worthy of revering. Her henceforth we adore.' $1^{1}$

This adoration of Reason went all over the Republic, and we may well ask, with Carlyle, what 'Reason herself thought of it all the while?' What can reason think of it, except that man 'is a born-worshipper,' if not of the God of all the earth, then of some foolish 'Mumbo-jumbo' made with his own hands. It was the beginning of religious reconstruction, and, in truth, religion could hardly begin again in a more pathetic way.

It is not very respectful to Napoleon the Great to make him take his place at the side of ${ }^{1}$ Fr. Rov. III. iv. 
Demoiselle Candeille. But he too represents the first crude attempt at restoration; and political liberty was not less caricatured in his tyranny than was religion in the worship of reason. 'The whiff of grape-shot' announced with sufficient emphasis for even that mad time to comprehend that the rights of insurrection were exhausted and that henceforth there must be peace on any footing, and order at any cost. The first foundations of the new world were laid, and laid, as needs must be, on the most rudimentary basis : namely, that of despotism. For it seems to be a universal law that any new principle, whether it be moral and concern merely the life of the individual, or social and concern the life of a nation, must first express itself in an elementary form, and operate crudely amongst the crudest energies. Thence it must travel upwards, evolving its content as it goes, and leavening, one by one, the elements of life within which it works. The content of a practical principle, like the meaning of a scientific hypothesis, comes out only in the process of its application. At first its signi- 


\section{IDEALISM AS A PRACTICAL CREED}

ficance is small, as it maintains itself with difficulty amidst the old propensities. The most momentous moral principle ever introduced into this world of ours was likened, by Him who announced it, to 'a grain of mustard seed, which a man took and cast into his garden.' ${ }^{1}$ But it gathers strength as it works amongst the elements of the old life. It breaks old habits, nay, by its new dedication of them it inspires them with the breath of a nobler meaning and transmutes them utterly: so that 'He that eateth, eateth to the Lord: and he that eateth not, to the Lord he eateth not.' 'For none of us liveth to himself, and no man dieth to himself.' ${ }^{2}$

This process is very slow, and its difficulty is proportionate to the worth of the new principle. There are no leaps in morals and politics, any more than in mathematics. It is as vain to try to superimpose an enlightened social polity on a savage people as to expect a beginner in mathematics to solve problems in the Differential Calculus. Man, in his pro-
${ }^{1}$ Luke xiii. 19.
${ }^{2}$ Romans xiv. 6, 7. 
gress, must run up the whole scale, chromatic notes and all, in learning moral and political wisdom. Nothing can be omitted. When history seems to have forgotten an aspect of the good it turns back for it. The religious enthusiasm and moral rigour of the age of Cromwell forgot the arts, and for the sake of the arts England had to rejoice for a time in Charles the Second. It is the whole of human nature which is to be saved, and the social edifice in which it is ultimately to express itself is to be a palace of many wings.

From this point of view even Demoiselle Candeille ceases to be merely pitiful or ridiculous. At the worst she stood for the better cause; for any poorest worship that is free is better than superstition, which always carries fear at the heart of it and abases the worshipper: and even if Reason be not God, Unreason is not amongst His attributes. And, as to Napoleon, if he did introduce a more masterful tyranny which drained the forces of the people still nearer the lees, he was, after all, a tyrant of the people's choice, and they gave 


\section{IDEALISM AS A PRACTICAL CREED}

to him the lives which he took. He exercised his authority in their name; and, as events ultimately showed, it was the hand of freedom which held the hilt of the sword. It was freedom that the French people would enforce on other nations, when they tyrannously demanded the death of tyrants.

Nor do I believe that, in either aspect of it, their work has proved vain. The word which has gone forth will not return empty. The ideal of social liberty, though it flickered faint for a time like a little candle in a high wind, never went out; and its light is destined yet to broaden downwards so that all men shall rejoice in it. Democracy was born at that time, a Hercules amongst the snakes, and it is devoting a growing strength to its more than twelve labours. In like manner the Ideal of all Ideals, namely, that of Religion, which is the dedication of the whole life to what is deemed highest, and without which, as I believe, no nation can live, shall yet be free,a religion which in every fibre of its credo shall commend itself to the reason of man, and 
satisfy his whole heart because it satisfies his mind.

What we have to observe in these events, then, is a new phenomenon: that of a new principle setting out to master the world. Man, now completely conscious of his right to freedom, proceeds to make that freedom good, to establish it amidst the extant powers of the world, an equal, and more, 'amongst their mightiest energies.' For he has to subordinate them to his spirit, and make the social, political, and religious order the exponents of his freedom. Hence we see old ways of life restored one by one. Truths were discovered in the repudiated creeds, institutions that were useful and ways of life which were honourable and of good report were found amongst the debris of the old social and political world. These were worked, little by little, into the new edifice. But not in the old way. History did not turn back quite along the old track. The French Revolution did not stultify itself. The old material was put to new uses, in obedience to the plans of the new architectonic conception 


\section{IDEALISM AS A PRACTICAL CREED}

of a Freedom which was to find no limits any more, except within itself.

But Freedom itself has changed its meaning in the meantime. It is no longer merely negative. It no longer sets the individual conscience against the universal order of the Church and the State. It is now divined that the State itself may be free, and the means of the freedom of its members. Men now regarded it with a new reverence. History was prized once more and the hoary experience of the world. The 'Year One' disappeared from the French Calendar, and men began to count once more from the opening of the Christian Erapending the time when they shall date the dawn of man's hope still further back, even 'when the morning stars sang together, and all the sons of God shouted for joy.' They discovered that wisdom had dwelt long in the world, and that, up to the measure of their capacity, it had been guiding from of old the blind and stumbling footsteps of men. Religion was brought back. The hard secular spirit which had cast its dusky shadow over 
the world, and darkened the ways of mankind, is being put to flight. The literature and the philosophy of the New Age-for by no other name can we call it-is instinct with the sense of a divinity within the world. And there is the promise that all history shall be deemed sacred, and not merely some nineteen centuries of it. Nature is also seen in a larger light, and the life of man is freighted with a new significance, even 'as they load a star with light.'

Hegel and Goethe, Carlyle and Wordsworththe poetic imagination in them catching first the rosy light of the new dawn and their philosophy following and broadening the light into the clearness and calm of the common day-these poet-philosophers, I say, are unique amongst their peers; and they are unique precisely in this-that they teach the world as it never was taught before, in any age, how sacred it all is and how interfused with the light divine. And shall I err much, think you, if I say that the practical business upon which the world is now engaged, whether in its commerce and its 


\section{IDEALISM AS A PRACTICAL CREED}

industries, or in its science and philosophy, or in the battles of the sects and the war of the politicians, is that of making real the ideals of these its prophets, giving them an actual footing and the right to rule amongst the common affairs of the common world? It is a great enterprise and meant to engage the best might of men for a long time to come. 
IV.

FREEDOM: AFTER THAT THE FULL CORN.

THE process which began with the Athens of Socrates and culminated in the French Revolution: The conception which underlies the process: The conception illustrated in the interaction of the Citizen and the State: The good state and citizen distinguished from the bad: A 'trade' and a 'profession'; the worker and his work: In what sense modern society is a Moloch: Positive freedom arrives when morality is socialized and society is moralized: The Morality, Philosophy, Art and Religion of the Modern Age are in concord: Their mission is only to illuminate: Its inevitableness illustrated in Wurdsworth ; but his spirit was prepared for it: Moral. 


\section{IV.}

FREEDOM: AFTER THAT THE FULL CORN.

Human history will not fit very accurately into any formula that the philosopher can devise; there are too many concurrent ages moving side by side-not without collision. Nevertheless, even without an excessive use of the imagination, we can see in the Athens of Socrates the beginning of a process which gathered strength for many centuries and culminated in the French Revolution. It was the process whereby man was learning the intrinsic greatness of his own nature as a spiritual being; and how it has the right, and must acquire the power, of determining its own faith and guiding its own behaviour. This process implied the gradual subjection to criticism of all the institutions founded upon the might 


\section{IDEALISM AS A PRACTICAL CREED}

of the stronger, and, in so far as they rested on that basis, their final overthrow. But, inasmuch as man must have an objective order in which to live, these same institutions, secular and sacred, were restored again, though not upon the old basis. Henceforth they must express man's own convictions, and be the objective counterpart of his inner life. It is this process of restoration which we have now to consider, with a view to comprehending something of the conditions under which it can take place. And, first of all, we must observe the presupposition that underlies the process-the idea that was operating within the stubborn and yet plastic material of the practical life of the age and gradually changing its whole character.

That idea found its prophetic expression in the imagination of the great poets and the reflective thought of the philosophers who appeared at the dawn of the New Epoch. It is, that Spirit is more and higher than any material or natural force, and has superior rights; and further, that the natural world is itself the symbol or 
phenomenal manifestation of Spirit. When man's mind gets entry into the arcana of nature, and finds what is working at its heart, it will see something akin to itself there. $H i s$ true thoughts will express its meaning; its reality manifests itself in his valid ideas. There is here neither chasm nor rift; but easy and constant intercourse. Nature is not a crass, material lump, 'or brass clock-work.' A mechanical explanation of it does not suffice; it is too obviously and intimately related to Spirit. Nay, it is itself spiritual, shot through and through with the rays of reason, and freighted with significance. As to the Social order-the State and its secular institutions and the Church with its rites and dogmas-it is not a restraint upon the liberty of Spirit, through which it must break in order to be free. Nor are passive and unquestionable obedience to them, on the one hand, or an antagonism that shall annul them, on the other, the only alternatives. The victory of Spirit over them can be much more complete. It may convert them. 'The DemiGod who had destroyed' the beautiful world, 


\section{IDEALISM AS A PRAC'TICAL CREED}

can build it again within, 'with greater majesty.' The Spirit of man may find itself in the social order, and much more fully than in the order of nature. The law within and the law without may coincide. Man may be obedient and yet free, and the more obedient because he is free. The social authority may be still steadfast, and the more steadfast and imperative because it is rooted in the heart of its subjects.

This, I believe, is clearly the essential message of the prophets of the Modern Age; and the carrying out of this message in practice is the work on which it is engaged. We are gradually reconciling ourselves to the conditions under which we necessarily must live without compromising either their authority or our own freedom; for we are discovering that their authority is rational and benevolent, and that submission to it is the pursuit of our own best good. We are re-instituting that authority, converting the law without into a law within; and thereby realizing the completest liberty.

Will you permit me to turn aside for a moment in order to illustrate and bring this 
truth more intimately home to our minds? We find that the modern State protects life and property, constrains equal justice between man and man, restrains the violence of the strong, fosters the weak by educating the young and providing for the needs of the aged poor. It does these things by authoritative enactments, and its decrees carry throughout the whole land much more thoroughly than in any rudimentary State. Now, are these regulations irksome? 'Certainly not,' we reply, ' not to the good citizen.' On the contrary they are what he himself desires, and up to the measure of his influence, he has helped to enact them. The taxation they imply is no doubt a burden, if it be regarded by itself; but the intelligent citizen does not regard taxation by itself, but in relation to the good it brings, which is the good of the whole State and comprises his own. It is thus not only possible, but it is a fact, that the will of the State and the will of the citizens can be, not two wills but one. And when such is the case liberty and law are reconciled. We do not see two powers confronting and confining 


\section{IDEALISM AS A PRACTICAL CREED}

each other; but one ethical spirit expressing itself at once in two directions, manifesting itself both in the free will of the citizen and in the authoritative imperatives of the State. And each sustains the other, as two wills always do when they are in agreement. The State finds its enactments ratified by the consent of the citizens, and the citizens find their desires realized in the legislation of the State.

In order to find the conditions which make this possible, let us consider for a moment an opposite instance. Let us observe, not the ideal State with ideal citizens, but an imperfect State with imperfect citizens. Nor need we travel far for our examples. When either the State or the citizen (or both, as is always the case) is morally crude and undeveloped there are constant collisions. The regulations of the State are irksome to the one, and the liberty of the citizens constitutes a danger to the other. The criminal, to the measure of his capacity, is an enemy of the social order and would destroy it; the autocratic State is an enemy to the freedom of its members and would repress it. 
Even when the citizen is not a criminal and the State is not a tyranny we have collision: whenever, in fact, the will of the individual is not socialized, or that of the State is not moralized; whenever, in other words, the citizen does not care much or wisely for the State, or the State for its citizens. In such circumstances, the sense of responsibility is weak on both sides; and each endeavours to use the other as means, instead of respecting it as itself an end. The citizen makes as much out of the State as he can, and the State consults the citizen no more than it can avoid. It will hoodwink him when it cannot flout his opinions, and enact his will only when it can delay no longer.

How far this description answers to any State that you know I cannot say. But this I can say:- that so far as such a condition prevails the State is weak and unstable. A political society which cares for only some of its members, while the others are denied the rights and obligations of citizenship, and are as aliens and foster-children on its hearth; or a State which hearkens only to the voice of a 'class' and is 


\section{IDEALISM AS A PRACTICAL CREED}

deaf to wider interests; or a State which protects and furthers only some of the conditions of a developed manhood while it neglects or repudiates others, can command only a limited loyalty. It is the scene of dissension, and the victim of factions, and it is too weak to move steadily towards ends whose worth is universal.

On the other hand, there is no more certain symbol of a limited and crude personality than heedlessness of the common good-of which the political State, with its institutions, is the representative. The $\dot{a} \pi \circ \lambda \iota s$, the man who does not carry his city within his heart, is a spiritual starveling. The measure of manhood is the fulness and generosity of its interests. The diviner the man the wider the world for which he lives and dies. It does not matter what a man does or has, if the current of his life sets inwards he is but a greedy animal with an unusually voracious appetite. Of Spiritual dignity he has none. If he cares for the State only as means of securing his private ends, and uses its waters to grind his own corn, or that of the class with whose interests he is 
immediately bound, he has but aggrandised his selfishness, and he is as great an enemy to his people as he is to himself.

The conclusion, then, to which we are driven by the contemplation both of the ideal and of the imperfect State and citizen is that the matter with which we are dealing is ethical in character. On the one hand, all moral questions for the individual, that is, all questions which are first in magnitude, are social questions. The bad man cannot help being a public calamity, and the good man, according to his power, cannot help being the stay and strength of his people. Even though he often errs for lack of insight, if the well-being of his people pulsates in his veins there is in him what will correct his errors. And it is wonderful how rarely and how little men err if their impulses are generous and their aims disinterested. On the other hand, questions of statesmanship are moral questions, even though morality is the one thing that no State can enforce. ${ }^{1}$

${ }^{1}$ For morality must be free, and its motives are the agent's own; and all that a political State can attempt to secure are 


\section{IDEALISM AS A PRACTICAL CREED}

The supreme problem of the State, it may be well to make clear, is not merely nor primarily to secure a particular form of government; but to learn what it ought to strive after under any form of government. We are inclined to assume that all will be well with the State provided its government be democratic; and we consider the democratic State to be that in which all its adult citizens have a share in ruling. But a State may be democratic in this sense, and still be corrupt and degenerate. It may be, what Plato conceived it, a slave to the clamour of passion and ignorance, and a minister to the greed of its constituentsa thing which no man can revere and from which every one seeks private gain. The question turns, once more, upon the character of its motives. Any government is good whose purpose is to serve the permanent interests of the governed, and which seeks to attain this end by evolving the character of its citizens, the means and outer conditions. It must let the moral life alone, "this year also, till it shall dig about it, and dung it: and if it bear fruit, well ; and, if not, then after that shall it be cut down."-Luke xiii. 8,9 . 
in which alone is its true strength. A democracy is the best form only because the political wisdom of the many is capable of being much greater than the wisdom of one, as the political folly of the many brings with it more irretrievable disaster than the folly of one. A democracy is capable of being either the worst, or the best kind of rule. It is the best when it is what Plato desired the State to bean institution for educating its citizens in all the virtues. For the State was an educational establishment for Plato, and all questions of statesmanship were moral questions.

Taking up both sides once more, we arrive at the conclusion that the individual finds his true end in the State, and the State in the individual. Every personal duty is a social obligation, and every just and wise political enactment has the evolution of the qualities of personality as its end. No State ever legislated well if it weakened the individuality or limited the enterprise of its constituents - a truth which some forms of modern Socialism have not laid to heart.

There is one more step still to be taken in 


\section{IDEALISM AS A PRACTICAL CREED}

the analysis of the conditions of a good State. The recognition of mutual obligation is not adequate, and the obligation itself is not completely binding until it is known to be selfimposed; and it is genuinely self-imposed only when the agent recognizes it as his own good. I can have no excuse for revolting against a line of action freely determined on by myself, and I can have no appeal against my own conscience. Nor can I ever justify myself for not seeking my own good. The obligation is both absolute and free.

But its absoluteness comes from its beneficence. Duty, the 'Stern daughter of the Voice of God,' is ' a light to guide' as well as ' a rod to check the erring, and reprove.'

'Stern Lawgiver! yet thou dost wear The Godhead's most benignant grace;

Nor know we anything so fair As is the smile upon thy face:

Flowers laugh before thee on their beds And fragrance in thy footing treads; Thou dost preserve the stars from wrong: And the most ancient heavens, through Thee, are fresh and strong." ${ }^{1}$

${ }^{1}$ Wordsworth's 'Ode to Duty.' 
Under the inspiration of duty thus conceived the social relations which knit men to one another within the State not only cease to be irksome bonds, but acquire priceless worth. His duties are the very best things a man has, and he cannot have too many of them; for what he cannot do is not his duty. He acquires value from his social context, like a musical phrase in a beautiful setting, or 'apples of gold in pictures of silver.' It is in his social context that he can exercise his spiritual functions, which, as Aristotle has shown, is 'happiness.' What is it, for instance, except his obligations to his fellowmen, 'his station and its duties,' which fills with interest and worth the life of the physician, or judge, or legislator, or teacher, or the maker and distributor of material goods? So far from confining his freedom, or inhibiting his life, they are its substance and steadfast joy. Deprive him of these, let him stand out of the social ranks refused, and he presents one of the most pitiful of spectacles we are ever compelled to witness-a willing worker holding out empty hands. To a man to live 


\section{IDEALISM AS A PRACTICAL CREED}

is his cause. The heaviest burden that ever a man has tried to bear is a life deprived of its motive. When Othello cries out that 'His occupation 's gone,' we seem to hear the strings of his heart snap. It has seemed to me, in its context, almost the most pathetic line that Shakespeare has written.

But I am reminded of the difference between a 'profession' and a 'trade'; a 'trade' is said to be that which a man follows in order to live; and a 'profession' is that to follow which a man lives. I acknowledge, not without sorrow, that there are stations in life and rounds of daily duty whose spiritual value for those who are engaged in them is very low; and, with the growth of modern invention and the increasing complexity of social arrangements, their number has vastly increased. The symmetry of character of the citizen of ancient Athens, which gave him an opportunity of exercising all his powers in turn, seems to be impossible in a modern State where duties are specialized. Nor is one-sided development the worst evil which we have to deplore. For men 
are being mechanized by the labour that should raise them; and society is often a parent which passes its children through the fire, a sacrifice to Moloch.

This is a matter which modern society has yet to consider, on its own account not less than on account of its victims. So far, we have not recognized our responsibility in an adequate way, nor seriously sought the solution of a problem which is as vital as it is difficult. The more enlightened modern States are striving to improve the conditions of labour.; but, so far, they have not seen their way clear to prohibit much of the labour which dehumanizes men. It is recognized, in a theoretic and academic way, that, even from the point of view of political economy, which is one of the most inadequate points of view for considering man, the waste of human qualities is the greatest of all waste. But even those whose gain would be most immediate if they could devise means by which all their employees would be reliable, sober, punctual, sensitive and faithful to their employers' interests, have either despaired of 


\section{IDEALISM AS A PRAC'IICAL CREED}

bringing this about, or, in many cases, have never seriously attempted to do so. It is difficult to say whether the men or the masters are most improvident in this respect. But the result is evident : it is the impoverishment of the general life of the State. Instead of economising the greatest of all productive forces, namely human qualities, they are being used up. Men are being scrapped like old iron.

I cannot doubt that labour is meant to dignify the labourer. He should arise from his daily work a better man. The energies which he sets free upon his handicraft are capable, as every honest workman knows, of coming back to him enriched; bringing with them more skill, the consciousness of a duty well done, and the satisfaction which the artist knows as his best reward. Provided this takes place, the difference between one occupation and another is of quite secondary importance. 'Two men I honour,' says Carlyle, 'and no third. First, the toilworn Craftsman that with earth-made Implement laboriously conquers the Earth, and makes her man's. Venerable to me is the hard 
Hand; crooked, coarse; wherein notwithstanding lies a cunning Virtue, indefeasibly royal, as of the Sceptre of this Planet. Venerable, too, is the rugged face, all weather-tanned, besoiled, with its rude intelligence; for it is the face of a Man living manlike. 0 , but the more venerable for thy rudeness, and even because we must pity as well as love thee! Hardlyentreated Brother! For us was thy back so bent, for us were thy straight limbs and fingers so deformed: thou wert our Conscript, on whom the lot fell, and fighting our battles wert so marred. For in thee too lay a god-created Form, but it was not to be unfolded; encrusted must it stand with the thick adhesions and defacements of Labour: and thy body, like thy soul, was not to know freedom. Yet toil on, toil on: thou art in thy duty, be out of it who may; thou toilest for the altogether indispensable, for daily bread.

'A second man I honour, and still more highly: Him who is seen toiling for the spiritually indispensable; not daily bread, but the bread of Life. Is not he too in his duty; endeavour- 


\section{IDEALISM AS A PRACTICAL CREED}

ing towards inward Harmony; revealing this, by act or by word, through all his outward endeavours, be they high or low? Highest of all, when his outward and his inward endeavours are one: when we can name him Artist; not earthly Craftsman only, but inspired Thinker, who with heaven-made Implement conquers Heaven for us! If the poor and humble toil that we have Food, must not the high and glorious toil for him in return, that he have Light, have Guidance, Freedom, Immortality? These two in all their degrees I honour: all else is chaff and dust, which let the wind blow whither it listeth. Unspeakably touching is it, however, when I find both dignities united; and he that must toil outwardly for the lowest of man's wants, is also toiling inwardly for the highest. Sublimer in this world know I nothing than a Peasant Saint, could such now anywhere be met with. Such a one will take thee back to Nazareth itself; thou wilt see the splendour of Heaven spring forth from the humblest depths of Earth, "like a light shining in great darkness." , 1

${ }^{1}$ Sartor Resartus, Bk. iii. (Helotage). 
In a society where such conditions rule the State and the individual will verily serve and strengthen each other. The citizen has but to stand in his station and perform its duties in order to fulfil the demands of citizenship. He is like an organ to the organism, best where he is-at his own work. There were then neither opportunity nor need for that vagrant knighterrantry which sends a man roaming for the opportunities of a good life, and we would witness less of that moral condescension and meddlesomeness which is so well intentioned and brings so poor a harvest. $\mathrm{He}$ would find right things to do where his skill is greatest, namely, in his own vocation, and perform therein the unique service which society demands of him. Doing that, none would deserve better of the State, for there is a valid sense, none more ultimate, in which all 'service ranks the same.' There is no humblest task which a high purpose may not ennoble; and no remotest post on the confines of a vast empire where the loyal citizen, like the lonely soldier on the velt, may not know that he is the representative 


\section{IDEALISM AS A PRACTICAL CREED}

of its majesty. And the State, on its part, if it is itself enlightened and worthy of such a citizen, will put forth all its force in case of need, in order to protect him and sustain him in his rights; for he is there on its account.

Thus does true freedom show itself to be no merely negative thing. It is emancipation, non-interference, exclusion, independence for the individual, and great, indeed, is the price which civilization has paid to secure these for him. But it is much more. It is life within the State; it is the life of the State within its members, for his duties to himself are duties to the State. A duty well done radiates far: 'shining like a good deed in a naughty world,' and the world takes note of it. The man who stands firm within his duty, stands not merely for himself but for his family, and not merely for his family but for his neighbours, not merely for his neighbours but for his State; nay, he stands for what is universally right because it is intrinsically right. 'Inasmuch as ye have done it unto one of the least of these my brethren, ye have done it unto me.' He has served the 
universal order, and the universal order is at his back to sustain him.

You have noted, I do not doubt, a certain consciousness of invincibility characterize a man who considers that he has done the right. It is one of the unique features of the moral consciousness, and worth considering as we pass. If his neighbours are against him, and his times condemn him, and he stands alone unsustained by that human sympathy which is like the sap of life, on what secret reservoir of strength does he draw? Having appealed in vain to the mind of his times, what remains to him? His answer is prompt and decisive. He appeals to the better mind of the times to come. His ultimate tribunal is 'the nature of things.' For duty, being an absolute obligation, implies that an unerring authority has imposed it. It is the will of the Absolute for philosophy, and of God for religion : and it must prevail. 'If God be for us, who can be against us?'

Herein is the ultimate achievement of the Spirit of Freedom. It cannot demand more. Duty being the conscious accord and complicity 


\section{IDEALISM AS A PRACTICAL CREED}

of the individual's will with the whole scheme of things, 'Who is he that condemneth?' What is there which can obstruct or hinder? Not the State, except when it is the enemy of its own welfare, nor humanity, except when it has lost its way. Spirit has come to its own by coming to itself, and the world which was alien and unfriendly has come over to the good man's side and is his partner in his spiritual enterprise.

Now, this, in its essence, is what the prophets of the Modern Age have been teaching 'in divers manners,' rending the veil between Nature and Spirit, so that the light that dwells 'between the cherubims' shall shine forth to the uttermost parts of the earth. For morality and philosophy it is a gradual process and toilsome achievement: because these are essentially a search and pursuit. They never count that 'they have already attained, either were already perfect; but they follow after, if that they may apprehend.' For art and religion it is not search but possession: it is immediate apprehension, the consciousness even now of the presence in nature 
and in human history of the object of their desire-a sense sublime and a disturbing joy. For all of them alike it is such a re-translation and transformation of the natural and secular, as to saturate them with spiritual significance. Indeed, this is the peculiar office of all the four-of Morality, Philosophy, Art, and Religion, namely, to reveal. They elicit the music that is already there, like the wind amongst the pines. Morality does not make a man his brother's keeper: it reveals the brotherhood which had been ignored. Philosophy does not devise. It discovers. The presupposition which underlies all its efforts is that the truth is there, if it could only get at it, embedded in the very nature of things. Art is not artifice. It holds the mirror up to nature, and the beauty of nature passes into its face. Religion does not invent its God, it finds Him : and, at its best, it finds Him everywhere. The structure of things is spiritual.

I daresay you have stood of a morning on one of the heights of your Blue Mountains and watched the rising sun warm into wondrous 


\section{IDEALISM AS A PRACTICAL CREED}

motion the mists that wrapped the world at your feet, in its unsubstantial mantle. Now here, now there, the veil is lifted for a moment and you catch a glimpse of a valley, deep below, lying in peaceful slumber. And ere long the whole landscape lies before you bathed in sunshine,-every rock and tree and rivulet distinct in each line and curve, and vocal with peace and its own particular beauty. The sun has created nothing: it has only brought light and warmth. It has set free the loveliness which was present all the time, called forth the curves and colours, and intensified the splendour of the scene. So does the light of religion illumine this world of ours, lifting the veil of secularity from its face, and raising the common duties of the common life into a higher value. Set in the large context of what is eternal, it becomes more clear to us that some things are worth the doing and others are better left undone: the good stands forth more distinct, and evil casts a darker shadow. Nothing has changed, except that the light has come. Religion prescribes no new duties; it 
has no province of its own, separate from the rest of life. But it gives a new significance to duty, and a new intensity to our aims. Our acts are seen to have vast consequences: they reverberate elsewhere, flinging their echoes beyond the walls of time.

It is a similar illumination which comes from Art and Philosophy. Art has no special sphere within which it may be confined, any more than Religion; and Philosophy has not a peculiar province of its own outside the sciences and the ordinary reflexions of men. Art seeks beauty and Philosophy seeks truth everywhere. The ' earth is theirs, and all the fulness thereof.' Art, Morality, Philosophy and Religion are nothing but points of view, spectacular heights from which Spirit may survey existence; but a point of view is a determining element in every landscape, natural or spiritual. They are protests against disorder, foes of discrepancy, witnesses on behalf of ideals, bringers of architectonic moods, by which facts are subordinated to some dominant vision, or passion, or principle and transubstantiated in the process, 


\section{IDEALISM AS A PRACTICAL CREED}

for they are interfused with a worth which otherwise they cannot have.

It is one of the characteristics of the Modern Age, that its Morality, Philosophy, Art and Religion are illustrating the same principle. Their methods, as needs must be, are quite different, and each moves independently in obedience to its own law, none undertaking the tasks of the others. But if their voices are distinct they make the richer harmony, and their concord is full of the happiest auguries for our age. There have been times, even in our own history, when their utterances were at variance, - when Philosophy was at war with Art, Art with Morality, and Religion with all the three. Even yet Religion is a somewhat reluctant partner, following rather than taking the lead. The cause of their discrepancy was, no doubt, that not one of them was near enough to the heart of reality to feel the throb of its single life. They mistook their mission, and did not understand themselves. But in this modern age the grasp of the meaning of life is so much more close, as 
regards the spiritual principle of it, that these different witnesses support each other's testimony. Our greatest modern poets and philosophers illumine one another. Modern poetry has proved itself, in a peculiar degree, to be 'the breath and finer spirit of all knowledge, the impassioned expression which is in the countenance of all science.' The imagination is not at war with reason, nor beauty with truth. The minor poet may, indeed, be still 'the idle singer of an empty day,' and there are philosophers yet who spin their abstractions from their own substance, detached from the living forces of their times; nor is it every theologian who has swept from his wings the clinging webs of antiquated traditions. But the greater poets and philosophers hide in no such retirement, and are engaged upon no such idly private tasks. They have little freedom, or, at least, little of the freedom of caprice. They express the deep impulse of their epoch yearning for a more harmonious life, and they obey necessities which choose and are not chosen, or rather, which are chosen because they choose. 


\section{IDEALISM AS A PRACTICAL CREED}

When a poet is at his best there is a certain inevitableness in his work. $\mathrm{He}$ is driven by his moods as by a strong tempest. $\mathrm{He}$ is not always the master of his own conceptions. He says things greater than he knows; and often enough it is only the slowly maturing experience of later times which can bring out and make good his meaning.

This was, I believe, the special, almost the unique character of Wordsworth at his best. When he is most himself, he is least merely himself. There is in him a certain 'massive passivity.' The beauty of the world played upon his soul, as upon an organ, and he seems to give forth a music not his own. He appears only to throw open the windows of his soul, and the beauty of sky and earth and the grave splendour of the life of man strike in. He contributes nothing: there is no need. He is not a master but a pupil, listening with a heart attuned to the majestic music.

'Come forth unto the light of things,

Let Nature be your teacher.' 
'She has a world of ready wealth,

Our minds and hearts to bless-

Spontaneous wisdom, breathed by health,

Truth breathed by cheerfulness.'

Poets have used Nature for many purposes; sweeping their hands over her strings they have elicited what music they pleased. It was the distinction of Wordsworth not to use nature at all. He was so trustfully placid, and lay so close to her bosom, that his thoughts rose and fell with her breathing. ' $\mathrm{He}$ had only to be quiet and attend.' 1

' The Spirit of Nature was upon me there;

The Soul of Beauty and Enduring Life

Vouchsafed her inspiration, and diffused

Composure and ennobling Harmony.'

He had only to gaze upon a lovely scene, but of itself

\section{'It became}

Far lovelier; and his heart could not sustain The beauty, still more beauteous.'

But he had to gaze with the poet's eye, and the appearance of mere receptiveness was as deceptive as is the seeming rest of perfect

${ }^{1}$ See Wordsworth, by Walter Raleigh (Edward Arnold), some of whose suggestions I have followed with gratitude and pride. 


\section{IDEALISM AS A PRACTICAL CREED}

motion. Truths break upon the imagination of the scientific man, as well as the poet, like the brightness of a sudden glory, and we call them intuitive. But they never come to the empty mind; for they are, in fact, the sudden blossoming of much apparently futile reflexion, like the flower of a plant which seemed all dead, and was all naked, throughout the winter. These intuitions come too, as a rule, to a mind refreshed, with all its energies pent within itself, ready to break out into a perfect activity which fuses past experience into one living mass, all aglow with feeling. Wordsworth speaks of 'a wise passivity.'

'Nor less I deem that there are Powers Which of themselves our Minds impress;

That we can feed this Mind of ours In a wise passiveness.'

But the passiveness and sensitiveness are those of the mind prepared, like the photographer's film for the light. To the making of the wisdom which can be passive, there has gone a long discipline of mind and heart-renunciation, strong restraint and high resolve. Browning 
tells us how Pompilia 'could rise from law to law,'

'The old to the new, promoted at one cry to the new service, not

To longer bear, but henceforth fight, be found Sublime in new impatience with the foe

How the fine ear felt fall the first low Word.'

'Thou at first prompting of what I call God, And fools call Nature, didst hear, comprehend, Accept the obligation laid on thee, Mother elect, to save the unborn child.' 1

But the fine ear, sensitive to the new command, had been long trained in the school of virtue. Pompilia had been 'true to touch in the past, practised in the right, approved in all docility to all instruction.'

Nor is there a greater fallacy than to think that the Beauty of the world comes at any time and to any kind of soul. Beauty is like truth, or moral worth, it comes not without much seeking. The soul that is steeped in sense, or disturbed with low ambitions for things that pass, never really possesses the loveliness of cloud, or sea, or landscape; and ${ }^{1}$ The Ring and the Book: The Pope. 


\section{IDEALISM AS A PRACTICAL CREED}

man may even render himself incapable of responding to it.

'In vain through every changeful year

Does Nature lead him as before;

A primrose by a river's brim

A yellow primrose was to him And it was nothing more.' 1

We find Wordsworth himself at times estranged from Nature's loveliness.

'The world is too much with us; late and soon, Getting and spending, we lay waste our powers;

Little we see in Nature that is ours.

We have given our hearts away, a sordid boon!

The sea that bares her bosom to the moon;

The winds that will be howling at all hours,

And are up-gathered now like sleeping flowers;

For this, for everything, we are out of tune:

It moves us not.'

If this quiet passivity, this peace and purity of spirit were intermittent and all too rare even to the poet, amidst the speaking silence of the hills of Cumberland, and in his unhurried age, what shall we say of ourselves, in this age?

I find you here, a young nation, with powers not yet defined, and possibilities not yet circumscribed. The virgin peace of a vast continent ${ }^{1}$ Peter Bell. 
wraps you all about; and one wonders if to its solemn quietude there responds a complementary tranquillity in your own souls, and if deep answers unto deep. Your city sparkles like a gem under your clear skies-with all its defects a fair thing in the midst of loveliness. May I ask without presumption whether at times you pause, so that its beauty may pass into the soul and saturate it with joy? I do not judge you, for I do not know. But one thing $I$ do know, that no man and no nation was ever truly great which did not commune with the quiet of the world-sometimes by means of reflective contemplation, as in the East; sometimes by means of Art, as in Greece and Mediaeval Italy; more frequently by means of religion. Israel's greatest statesman was called forth from the land of Midian, where he tended sheep. The most picturesque figure amongst its prophets was a dweller of the mountains of Gilead, and lodged in a cave at Horeb, the mount of God. These men mustered their powers amidst the silences. Cromwell, who rode the wildest storm which ever broke over your hard-tried 


\section{IDEALISM AS A PRACTICAL CREED}

'Home'-that other gem amongst the seas, 'the little England with the mighty heart'Cromwell had his times of quiet, his 'lown place,' his sure refuge. And so had his unrivalled Ironsides. And, most assuredly, it cannot be well with you here, or with us at home, who are heirs to the still unexhausted inheritance of the stern virtues of the Puritan Age, if we lose utterly this quietness of spirit, this solemn delight in deep communion with the might and majesty of the world, and of the mind of man. Either through religion, or through Art and the wisest literature, or, better still, through all of them, we shall and must listen to the murmur of their deeper meaning-otherwise we can not prosper. 


\section{V.}

\section{THE IDEALISM OF WORDSWORTH AND BROWNING.}

Whат we ordinarily expect from the poets and philosophers, and the consequences for them and for ourselves: Their message to the present age: Wordsworth denied 'a system and ordered philosophy': Stupid notions about philosophic systems and exaggeration of the difference between poetry and philosophy: Men who are not judges of either: The prose view of the world not necessarily true: Earnestness and thoroughness of Wordsworth's Idealism: Wordsworth and Browning contrasted: Browning's Agnosticism as regards the intellect, and his Idealism of Love. 



\section{V.}

THE IDEALISM OF WORDSWORTH AND BROWNING.

I ventURED, in my last lecture, to augur well of the present age from the concord of its aesthetic, intellectual and ethical ideals. I ventured also to set it down as a primary condition of its prosperity that it should hold some one at least of these ideals in high regard, as the most precious element of its life, to be cared for and fostered beyond every other thing.

But can this faith in the practical efficacy of ideals be maintained? Do the imaginations of the poet and the theoretic constructions of the philosopher verily mean much in a people's life? Of the investigations of the man of science, we have no doubt. These issue in discoveries, and the discoveries in inventions, whose 


\section{IDEALISM AS A PRACTICAL CREED}

usefulness for man, as means for mastering the material world, is palpable and greater than can be measured. But we hardly expect such a service from the exponents of ideals. They see visions and dream dreams and have their own great qualities, none nobler or more divine; but, amongst these qualities, we do not look for hard and unadorned utilities. The Idealists are not of this world, nor do they help us directly in the conquest of it. It is enough if they can allure mankind at times to forget the pressure of its woes. We are content if the poet charms the vacant hour, or the philosopher stimulates the dulled intelligence to some transient sense of the mystery of being. We should not dream of making the poet our guide along the muddy ways of life, or of converting our philosophers into kings.

The consequences of this attitude are natural and inevitable enough. We turn aside from the poets when we are engaged upon the real business of life, and make them companions, at the best, of only our lighter hours. And this means that we do not really believe their 
message, and have no use for it. They would feed us on ambrosia and manna: what we want is bread and butter.

Carlyle tells us that "The old Arab tribes would gather in liveliest gaudeamus, and sing, and kindle bonfires, and wreathe crowns of honour, and solemnly thank the gods that, in their Tribe too, a Poet had shown himself. As indeed they well might; for what usefuler, I say not nobler and heavenlier thing could the gods, doing their very kindest, send to any Tribe or Nation, in any time or circumstances?' We behave otherwise. 'We English find a poet, as brave a man as has been made for a hundred years or so anywhere under the Sun; and do we kindle bonfires, or thank the gods? Not at all. We, taking due counsel of it, set the man to gauge ale-barrels in the Burgh of Dumfries, and pique ourselves on our "patronage of genius." '1 We keep Wordsworth and Browning waiting in our forecourts, like Johnson upon Chesterfield, for fifty years-not merely for recognition, but for the wages of ordinary honest

${ }^{1}$ Past and Present. 


\section{IDEALISM AS A PRACTICAL CREED}

hand-labour. We tarry so long, bringing patronage, that we set Carlyle, the prophet we needed most of all, thinking of a shovel and pickaxe in the American backwoods, all but breaking the proud heart: 'Thou art not fit for that either, my good fellow.' And we are so consistent in our conduct, so persevering in our neglect, that we are compelled to seek its meaning.

What can it mean, except that we deem such men to stand outside our lives, aloof from our real interests? Men do not ignore what they can use, nor are they usually slow to acknowledge the benefits which they recognize. But the votary of the ideal, from of old, is not recognized. ' He hath no form nor comeliness; and when we shall see him, there is no beauty that we should desire him.' Either his message lacks truth, or its import is lost upon us. Either he is not worthy of that genuine homage which is obedience from his fellow-men, or their standard of worth is wrong. And we may well ask where the blame lies. Do ideals lack practical efficacy from want of contact with 
the nature of things? Or are men prone to weigh the issues of life in a false balance : careful, alas! of the husks, careless of the grain?

What manner of ideals the prophets of the modern age have declared as the truth of things, I have already indicated in briefest fashion. The essence of their message, their 'scheme of salvation,' whether it was delivered in the form of Art or Morality, of Philosophy or Religion, was the conviction that this world of ours and the soul of man are saturated with spiritual significance. They had found deliverance from the cramping dualisms of the previous age. Spirit and nature, man and the world, things sacred and things secular, did not stand opposed and exclusive; but 'the Canopy of Heaven was over all,' bringing harmony and reconcilement. These apparent opposites were found to imply one another, to subsist by mutual interfusion, to interpenetrate so that they cannot be rent asunder. Mind upholds and is upheld by the world, like a net in the open sea. Form expresses matter, and matter fills out the form. Spirit sees its own expression in the world, $\mathrm{K}$ 


\section{IDEALISM AS A PRACTICAL CREED}

and communing with it holds discourse with itself.

Natural science corroborates the truth which the poets and philosophers divine. Man, it tells, is not an exception to the scheme of things, or a divine after-thought and addendum to a dead world. He is part of nature's tissue. $\mathrm{He}$ is brother and blood-relation to the brute; nay, he was present in promise at the dawn of being, waiting to be evolved. The potencies of his spirit slumbered amongst the molten masses and the fiery vapours. For all is one scheme. Evolution tolerates no break, brings forth nothing altogether new, permits nothing to become altogether old. It builds the living present from the dying past, forgetting nothing, abandoning nothing in its course, least of all the dormant promise of the emerging ideal. That is immortal, present from first to last and maintaining itself in every change. Every step in the cosmic process is its self-emancipation, until at length it stands declared in a form worthy of itself; and it shows itself as spirit.

In the light of this, the last achievement, the 


\section{WORDSWORTH AND BROWNING 147}

meaning of the whole process becomes visible, and Nature, bereft of life by the abstract dualisms of the previous age, comes to her own again. Presenting her as instinct with purpose and order and beauty, the poetry and philosophy of the present day, present her in her truth. For she is their treasury. She possesses what they find, reveals what they discover, bounteously yields all that they gain. Their thoughts are her communications: she fills their mind.

Enlightened by his world, guided and restrained by its mute laws, man achieves some knowledge, and acquires some wisdom and strength. Left to himself he were utterly without resource, a blind soul groping in an empty void. Man becomes strong only in the strength of nature; for he is sustained by her verities. She is his coadjutor and partner in the enterprise of life. On the other hand, nature has meaning and highest worth only in relation to the man she evolves. She blooms into full significance only in his spirit. For spirit holds together what else were scattered, overcoming the discreteness of time and space and circum- 


\section{IDEALISM AS A PRACTICAL CREED}

stance. Only where there is mind is there order, or beauty, or purpose, or significance.

It is this borrowing and lending which modern thought has discovered, and the conditions which make such commerce possible. Between dead nature and an empty mind it could, we believe, never arise. The wealth of the world would lie inert and useless, and the powers of man would be for ever dormant, were they by nature divorced and isolate. Why! your very gold mines were but dross for your aborigines. But man and the physical world are not alien to one another; they are interfused, like mind and its experience.

Such interchange of commodities between man's spirit and nature's is illustrated in many poets; but it is in Wordsworth that the real depth of their inter-communion is most impressively revealed. And their intercourse rested for him upon the community of their being, the essential unity of their substance. For him there was between them hardly a distinction of function, or a possible delimitation of domain. They partake in one another's moods, 
because the same presence dwells in both. There is no break or boundary between them, any more than there is between the churchyard of a sweet English village and the quiet meadows beyond.

'Where holy ground begins, unhallowed ends,

Is marked by no distinguishable line:

The turf unites, the pathways intertwine.'

Nature blends with man, and man with nature, as the colours fuse and fade into one another in the evening sky. There is no passion, nor purpose, nor brooding thought which is not nature's very own. Gladness, love, the restful quietude of a stable majesty, she possesses and feels. They are her emotions. - Wordsworth educes them from Nature; he treats her as a 'mystic text, to be deciphered,' by those who hold in their own souls the key.

'He looked-

Ocean and earth, the solid frame of earth And Ocean's liquid mass, in gladness lay

Beneath him. Far and wide the clouds were touched, And in their silent faces could be read Unutterable love. Sound needed none Nor any voice of joy: his spirit drank The spectacle; sensation, soul and form, 


\section{IDEALISM AS A PRACTICAL CREED}

All melted into him; they swallowed up

His animal being; in them did he live, And by them did he live; they were his life.' 1

It is not easy to realize the depth of this interfusion of spirit with spirit. An intercommunion that is voiceless because the mutual understanding is deep, a love which is so intimate that the boundaries between soul and soul are obscured, we rarely witness: never, probably, except in the deep recesses of the happiest wedded life, where much has been enjoyed in common and much endured. But Wordsworth, at times, rose to this sublime altitude in his communion with the natural world : natural for him no more at such periods, but a breathing soul.

But what are we to make of such an attitude towards Nature? How are we to understand such passages as these, which constitute the main body of Wordsworth's greatest poetry? That their poetic value is unsurpassed, and possibly unsurpassable, no one now would care to deny. They are the evidences of his Genius,

1 The Wanderer. 
and the speaking splendour of his unique endowment: by them, 'he has widened the sphere of human sensibility, and introduced a new element into the intellectual universe.'

But, 'are they true?' is the question that recurs. Did the 'Ocean's liquid mass lie in gladness,' and was there 'unutterable love in the faces of the clouds'? Or was not Wordsworth just taking the licence, pardonable, nay admirable in a poet, of borrowing fair conceptions from his own peculiar realm of beauty, and clothing an inanimate and indifferent world with a spiritual splendour which was in no wise its own? Was he idealizing the real; or did he, in virtue of the intimacy of his deeper love, see more deeply into the true essence of its being than other men?

For our purpose in these lectures the question is fundamental; perhaps I may add that it is fundamental, too, for the true understanding of the poet.

If we listen to the exponents of Wordsworth, we shall find them at variance on this matter One eminent man of letters tells us that 'it 


\section{IDEALISM AS A PRACTICAL CREED}

is best to be entirely sceptical as to the existence of system and ordered philosophy in Wordsworth. When he tells us that

$$
\begin{aligned}
& \text { 'One impulse from a vernal wood } \\
& \text { May teach you more of man, } \\
& \text { Of moral evil and of good, } \\
& \text { Than all the sages can,' }
\end{aligned}
$$

such a proposition cannot be seriously taken as more than a half playful sally for the benefit of some too bookish friend. No impulse from a vernal wood can teach us anything at all of moral evil and good.'

Common sense endorses the criticism. So does common experience of the common poets. The warning against being too generously credulous might even be deemed unnecessary. When poets endow nature with the attributes of man, they are manifestly, as a rule, indulging their phantasy, and they do not mean precisely what they say. We can distinguish between their imaginative flights and their sober faith without doing them any serious injustice. But can we do so with Wordsworth? Or are we not deterred by the fact that he wrote in this 
manner, and uttered these thoughts throughout the whole of his highest poetic life? It is precisely when he deals with such themes as these that his diction acquires that mass and weight which can hardly be accounted for unless it was laden with the convictions of his deliberate faith.

That Wordsworth had 'no system or ordered philosophy' is true in a sense. These imply a method and a spirit of working which are not compatible with the passion and intuition of poetry. Philosophy carries us far 'into the region of abstraction and division, of controversy and contradiction.' Analyis, which is the weapon of death, is so constantly in its hand, and the synthesis it seeks is so far beyond its power to complete, that the element in which it lives 'must always be dangerous, and may even be a fatal element to the poet.'

Nevertheless, the distinction between poetry and philosophy is easily exaggerated. It is even apt to disappear when they are at their best. 'In the case of the greatest poets we are driven by a kind of necessity to ask what was their philosophy.' The poet 'looks steadily 


\section{IDEALISM AS A PRACTICAL CREED}

at his subject,' and his subject is human life, and Wordsworth claimed to have done this in fulfilment of his own mission. For, to him, 'poetry was the image of man and nature'; 'its object is truth, not individual and local, but general and operative' - a definition which might stand for the object of philosophy. On the other hand, we are driven to feel the poetry of the greatest philosophers. It is only those who entertain 'a lurking consciousness that the realities of the muse are but shows' who can avoid giving the name of poetry to the massive conclusions and the profound enthusiasm which come with the long-delayed and hard-won affirmations of a Plato or Spinoza. The Muses are sisters, and of one blood.

There is much nonsense in the talk about philosophic 'system' - a parade of mechanical order where it does not exist. One would think that a philosophy is an artificial contrivance, compact and complete; its parts fitted together, morticed and jointed into premisses and conclusions, that can be pulled down and put up again at one's pleasure. 
But no system of philosophy ever answered such a description: not Plato's, or Aristotle's, or Kant's, or Hegel's, nor even Spinoza's; for Spinoza's geometrical method is only surface show. The philosopher's world is too large, and he feels it in too many ways; its organic filaments are too numerous, its contradictions too intense, and the unity of its life is too intimate to permit the specious display of the facile connexions of a barren logic. Philosophy is, indeed, an attempt at coherent thought, it employs argument and aims at proof. But it seeks these where common sense seeks them, seeking them with somewhat greater persistency. There is no mode of thought which is less esoteric, or more frank in its communion with the open world. Nay, there is none which is less the victim of its own hypotheses; for it examines the presuppositions which ordinary thought lets pass, and shows its best wisdom and its greatest care in the choice of its premisses. Having chosen them, it treats them as the medium of its thinking, and the light of all its seeing. But it is continually 


\section{IDEALISM AS A PRACTICAL CREED}

bringing them to the test of fact, and its application of them is their continuous new birth and recreation. The 'system' grows like a living thing, which experience $i s$, for its roots are in the still waters.

The relation between the poet and the philosopher is described with precision in a letter of Goethe to Jacobi- ' You can easily imagine my attitude to philosophy,' says Goethe. 'When it lays itself out for division, I cannot get on with it; indeed I may say that it has occasionally done me harm by disturbing me in my natural course. But when it unites, or rather, when it confirms our original feeling as though we were one with nature, and elevates it into a peaceful intuition that under its external $\sigma u ́ \gamma \kappa \rho \iota \sigma \iota s$

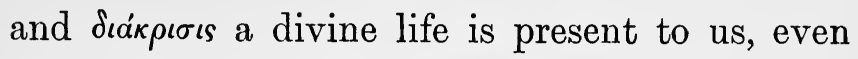
if we are not permitted to live such a life ourselves - then it is welcome to me.' 1 Regarded in this way it is altogether impossible to deny 'philosophy' and 'ordered system' to Wordsworth. To do so were to take away from him

${ }^{1}$ Quoted by E. Caird, Essays on Literature: 'Goethe and Philosophy.' 
the main secret of his strength. He had his enduring view of life, and an inconquerable conviction as to the nature of the outer universe. He held it to be true as a matter of fact that the moral world and all its play of passion ' extended far beyond the domain of human nature.' No philosopher held to his conception with greater tenacity; no scientific truth was maintained with more literal seriousness. There is a slow and massive persistence, a deliberate resoluteness, in his thinking upon these matters, as of one who had planted his foot upon a rock and will not lift it.

'To every natural form, rock, fruits or flower, Even the loose stones that cover the high way, I gave a moral life. I saw them feel Or linked them to some feeling: the great mass Lay bedded in a quickening soul, and all That I beheld respired with inward meaning.'

I find in such passages a spiritual realism which nothing can daunt: a faith and a philosophy that will brook no exception to their sway. They are the utterances of one who trusts his principles, and will follow them home. There is more than metaphor or similitude, or 


\section{IDEALISM AS A PRACTICAL CREED}

analogue here: Wordsworth meant his weighty words, for he believed seriously in 'Nature's depth of soul.' There is more even than that anthropomorphism which projects man's qualities outwards. The poetry, like the religion, of the world's youth might be content with anthropomorphism. Wordsworth rejects it. Man, in his view, was more recipient than donor.

$$
\text { 'I would not do }
$$

Like Grecian artists, give thee human cheeks, Channels for tears; no Naiad shouldst thou be,Have neither limbs, feet, feathers, joints nor hairs:

It seems the Eternal Soul is clothed in thee With purer robes than those of flesh and blood, And hath bestowed on thee a safer good; Unwearied joy, and life without its cares.' 1

There is one passage in the Ethics of Aristotle which critics point to as a rare, if not the singular occasion, when the calm of his scientific spirit is broken by enthusiasm. It is where he sees man's life of contemplation coming into touch, nay, into unity with the life divine. Such contact and fusion, he maintains, is not possible except for intermittent moments. The divine is high, man is weak and finite. $\mathrm{He}$ ${ }^{1}$ Brook. 


\section{WORDSWORTH AND BROWNING 159}

cannot long maintain himself at that altitude : the atmosphere is too rare and his own nature is too crass.

There is something analogous in Wordsworth's view of man's communion with nature. She is so replete with spiritual meaning, so 'majestical,' that man is not fit to hold converse with her, nor can he receive of her fulness, except in his sublimer moods. He must be humbled first, in order to be raised afterwards. He must be

'Trained

To meekness, and exalted by humble faith,' ere he can

' Hold up before the mind, intoxicate With present objects and the busy dance Of things that pass away, a temperate Show of objects that endure.'

Nay, there is need of preparation, according to Wordsworth, in order even to understand the poet's communion with the world. 'And for the sublime-if we consider what are the cares that occupy the passing day, and how remote is the practice and the course of life from the sources of sublimity, in the soul of man-can it be wondered that there is little 


\section{IDEALISM AS A PRACTICAL CREED}

existing preparation for a poet charged with a new mission to extend its kingdom, and to augment and spread its enjoyments?' 'Every author, as far as he is great and at the same time original, has had the task of creating the taste by which he is to be enjoyed.'

Can it be that it is the lack of such preparation which leads us so often to apologize for Wordsworth's way of presenting the real as ideal? 'He was inspired,' we say. 'When he spoke in his great fashion, he was the vehicle

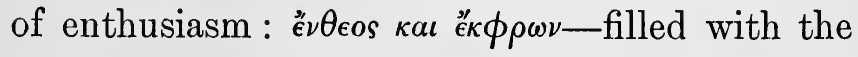
God, but out of his mind. For the light he saw really never was on sea or land: the presence which disturbed him with the joy of elevated thoughts was not in nature, but in himself.' Thus, by one means or another, often enough unconsciously, do we take away the import of his message, and convert his deepest faith into matter for mere delectation. Translated into plain speech our attitude towards him means: ' he was not himself at the time, but the mouthpiece of a spirit which was not the spirit of simple truth.' It lied, in fact, but lied magnifi- 


\section{WORDSWOR'TH AND BROWNING 161}

cently. For is it not certain that the nature he adorned, and then adored, is dead, secular, crass, material, and void of all intelligence? Do we not find it difficult even to raise the issue seriously as between our own common-sense with its materialistic realism, and the idealisms of the poets and philosophers?

Nevertheless, it was to raise this precise issue that the poets and philosophers of our day have laboured. Press as we may the distinction between the truth of poetry and the matter-offact of literal observation, which is the kind of truth that philosophy seeks, Wordsworth must still be regarded as a deliberate idealist and a very great one. "As philosophers have said that the 'real is the rational,' so a poet may be allowed to declare that "the real is poetic," and the concord between them is far deeper than their difference. Indeed, their quarrel is not with one another, but with mere common sense and the ordinary understanding, which assume that they take the world 'as it is,' but which really interpret it in the light of transient needs and 'the cares that occupy 


\section{IDEALISM AS A PRACTICAL CREED}

the passing day.' For the eye brings with it much of what it sees-the eye of the man of the world, no less than that of the philosopher and the poet. There is need of the consecration of the self ere the world can be consecrated; nor is it less true that it is a desecrated self which finds a desecrated universe.

The agreement of the poetic and philosophic view of the world is easily accounted for. It is the unique quality of the great poet and the great philosopher that in all things they see the whole. The world shows itself rational, and it shows itself poetic, under the same conditions, namely, when it is viewed $s u b$ specie aeternitatis. Then its 'accidents' are divested of their unreason, and its events cease to be crude occurrences. The poet finds this unity by a method of his own, and combines the sensuous material as a poet should. Relations which are causal to the man of science, or logical to the metaphysician, become in his hands lyrical, mystical. Truth breaks into measured music at his touch. But the method of their attainment of the sense of unity, 
and the way in which they respond to it, is a matter of secondary consequence: the central fact is, that they can admit no break in the continuity, no ultimate disconnexion in their object, no mere chance or brute accident. It is ignorance and the lack of love and of the insight which love brings that conceal the connexions of the world, and make us deaf to its harmonies.

For Wordsworth, most of all amongst the poets, there was one principle in the universe, and the principle was spiritual. No form of being was void of it.

$$
\begin{aligned}
& \text { 'Spirit . . . knows no insulated spot, } \\
& \text { No chasm, no solitude ; from link to link } \\
& \text { It circulates, the Soul of all the world.' }
\end{aligned}
$$

To deny him this conviction, or to reduce his conviction into a sensuously delectable makebelieve, is to degrade the poet himself into an 'idle singer of an empty day.' It is not possible.

But, admitting that this view was held by him as a theory, held seriously and even literally, can it be admitted by us? This, I conjecture, 


\section{IDEALISM AS A PRACTICAL CREED}

is the question that lies at the background of all your thoughts. We shall come to it by and bye. In the meantime may I ask you to try to maintain a mind unprejudiced? I do not wish you to conclude that the poetic version of the world is the true version. But, on the other hand, I should like to warn you against what we know is the greater danger, namely, the assumption that the only version which can be true is the prose version.

There are men for whom the best things of life are not real, and we call them shrewd. They are the men who interpret the motives and actions of their fellows by their meanest aspects, and think thereby that they see beneath the show of things. The man-of-the-world does not believe in goodness that seeks no reward. Devotion to the public good for its own sole sake; the simplicity of heart that does not care very much for power, or rank, or consideration, or wealth, is either false display, or folly - ' the foolishness of the Cross,' as St. Paul called it.

But it is just possible that these things verily 
are, and that the worldling's interpretation of the world is wrong. For, after all, the mind of man must make what it receives. The eye must construct the beauty of the evening sky, even although it is there to be constructed: the ear must catch the music in order that the music may be. There are no harmonies for the tuneless ear, nor possibly any beauty of scenery for a cow. Verily it requires mind to commune with mind, love to respond to love, and a spiritual soul to know the spiritual world. Some one told Johnson once, that he was no gentleman. 'Sir,' was the reply, 'you are no judge!'

Peter Bell, with his prose mind, may be an incompetent judge of the verities of this world of ours, and the man-of-the-world, with his little faith in God and his great trust in the Devil, may, after all, not be taking things as they are. The music of the universe may have been spilled into deaf ears, and its glory unfolded over an empty eye-socket.

'He roved among the vales and streams,

In the green wood and hollow dell; 


\section{IDEALISM AS A PRACTICAL CREED}

They were his dwelling, night and dayBut Nature ne'er could find the way Into the heart of Peter Bell.

'At noon, when by the forest's edge $\mathrm{He}$ lay beneath the branches high, The soft blue sky did never melt Into his heart; he never felt The witchery of the soft blue sky!'

The witchery was there; but it was not there for Peter Bell, nor for his ass.

And who shall cast the first stone at him? For are we not all beings upon whom physical needs press first and with an urgency which is imperious; and is not the ascent through sense to spirit arduous? Is it not difficult not to take for granted, as a thing of course and obvious, that the natural is alone verily real and significant, and that all the rest is but pleasing glamour? The risk of such a presupposition is, possibly, greatest of all in a community like yours, constituted as it is in great measure of men in whom the spirit of industrial and commercial enterprise was so strong as to break their old faithful intimacies, and to bring them across the vast and barren 
seas to brave the isolated expanse of a continent all untamed. In the old and comparatively safe life of the mother country, where the many paths of life have been travelled smooth, and there is wealth of matured experience and spiritual tradition, there was much to sustain the individual's higher moods of mind. In this new world, it would not have been surprising if naught remained of a culture left behind except its fading echoes. But I see evidences that, in embarking, your forefathers did not forget their spiritual freightage. And I trust that as you proceed in the construction of your national life, amidst the collision of parties and the strife of interests, the spiritual view of things will not be permitted to become obsolete; but that you will ever set value upon your churches, your schools, and universities, and on all other institutions, if there be any, whose mission is the making of men. You will probably conquer as you stand even though affairs press hard; for neither a nation nor an individual can constrain nature into serviceableness without learning something of their own needs and powers in 


\section{IDEALISM AS A PRACTICAL CREED}

the process. But your victory will be the more sure for your idealists - for men to whom religion is a great power; and the love of learning, and especially of the so-called 'useless learning' of the humanities, a great passion.

The significance of Nature for man depends upon the evolution of man's own powers, as a book has meaning only to him who can read the language in which it is written. Nor have the idealists in their exaltation of Nature forgotten this truth; or, while making man akin to her and setting him to learn from her as a pupil at her feet, overlooked the significance of his mind. It has been easier, it is true, both for the poetry and for the science of modern times to apprehend the order of the material world than to conceive the reign of law amongst the capricious fortuities of human volitions; for men's purposes are held to be free, and freedom seems to be opposed to law; and their interests are multitudinous, and seemingly all entangled and at war.

Nevertheless, even Wordsworth did not always equalize Nature with man. His spiritual inter- 


\section{WORDSWORTH AND BROWNING 169}

pretation of the world was the counterpart, if not even the consequence of his mind's descent into itself by 'treading the steps of thought.'

For it is in the mind that the elements and conditions of truth and beauty, elsewhere dispersed and sown abroad, are brought together and blended into harmony. Hence man's spirit is

'A thousand times more beautiful than the earth On which he dwells:... ... . itself

Of quality and fabric more divine.'

Frail as man is, and mortal, yet the 'liberty divine' is his,

'To roam at large among unpeopled glens

And mountainous retirements, only trod

By devious footsteps; regions consecrate

To oldest time; and reckless of the storm

That keeps the raven quiet in her nest,

Be as a presence or a motion one

Among the many there; and while the mists Flying, and rainy vapours, call out shapes

And phantoms from the crags and solid earth As fast as a musician scatters sounds Out of an instrument. . . .

What a joy to roam, An equal amongst mightiest energies.' 1 


\section{IDEALISM AS A PRACTICAL CREED}

Thus Wordsworth's ultimate theme was Man; but not man psychologically considered as in previous times; for though the individual mind

'Keeps her own

Inviolate retirement,'

she is not isolated, nor does she beggar herself by exclusion: she comprehends the world in her own depths and rounds it off within herself. Hence her marvel, and her mystic greatness.

'Not chaos, not

The darkest pit of lowest Erebus,

Nor aught of blinder vacancy, scooped out

By help of dreams-can breed such fear and awe

As fall upon us often when we look

Into our Minds, into the Mind of Man-

My haunt, and the main region of my song.' ${ }^{1}$

'There is,' he tells us in one of his great prefaces, 'a meditative as well as as a human pathos; an enthusiastic as well as an ordinary sorrow; a sadness that has its seat in the depths of reason, to which the mind cannot sink gently of itself-but to which it must descend by treading the steps of thought.' In youth, Nature was to him 'all in all.' 


\section{WORDSWORTH AND BROWNING 171}

'The sounding cataract

Haunted me like a passion: the tall rock, The mountain, and the deep and gloomy wood, Their colours and their forms, were then to me An appetite.'

That time passed; but he fainted not, nor mourned nor murmured. Other gifts had followed, bringing 'abundant recompense.'

'For I have learned

To look on Nature, not as in the hour Of thoughtless youth, but hearing often-times The still, sad music of humanity.' 1

Reflexion, like a quiet evening spreading in his soul, brought out the deeper meaning of the world-a holy time,

$$
\text { 'Quiet as a Nun }
$$

Breathless with adoration.'

For he found 'the gentleness of heaven brood' over the whole universe.

'Listen! the mighty Being is awake, And doth with his eternal motion make A sound like thunder-everlastingly.'

He found God everywhere. Everywhere was the revelation of the same Eternal Spirit, to which all things owed their meaning, their music, and their inmost being and substance.

1 Tintern Abbey. 


\section{IDEALISM AS A PRACTICAL CREED}

'And I have felt

A Presence that disturbs me with the joy

Of elevated thoughts; a sense sublime

Of something far more deeply interfused,

Whose dwelling is the light of setting suns,

And the round ocean and the living air, And the blue sky, and in the mind of man:

A motion and a spirit, that impels

All thinking things, all objects of all thought, And rolls through all things.' 1

It was for her testimony to this Presence, which was her own ideal meaning, that he loved Nature so much, and found through intercourse with her the stay of his faltering footsteps, even when he trod the mazes of man's history,

\section{'Intent to weigh}

The good and evil of our mortal state.'

'Therefore am I still

A lover of the meadows, and the woods, And mountains; and of all that we behold From this green earth.'

Therefore am I

'Well pleased to recognise

In nature and the language of the sense The anchor of my purest thoughts, the nurse, The guide, the guardian of my heart, and soul Of all my moral being.' 2
1 Tintern Abbey.
${ }^{2}$ Ibid. 
The meaning of the world broadened for him, while sense deepened into thought. As the rill becomes a stream and the stream a broad river, and still they carry within them an intuition of the boundless sea which is their home, so in early youth and thoughtful manhood the murmur of the Spirit of all the world was ever in the poet's ears; and it grew till it possessed his soul enduringly. Men call this 'Natural Religion': it is Spiritual Religion with Nature as its all too narrow vessel.

Browning's interest in man was more, and his interest in Nature less direct than Wordsworth's. The contrast between them, brief as it must be, may prove instructive.

Wordsworth could at no time have described himself as Browning did in his Preface to Sordello: 'My stress lay on the incidents in the development of a soul; little else is worth study. I, at least, always thought so.' But Wordsworth lays no 'stress' on the objects of his contemplation, he was passive in their possession; there are few 'incidents' in his poetic life, it was too full of their omnipresent 


\section{IDEALISM AS A PRACTICAL CREED}

meaning; and he found much besides man 'well worth study.' He was like one who stood on a bold headland looking far out upon the open ocean.

' On Man, on Nature, and on human life, Musing in solitude, I oft perceive

Fair trains of imagery before me rise,

Accompanied by feelings of delight

Pure, or with no unpleasing sadness mixed.

To these emotions, whencesoe'er they come, Whether from breath of circumstance,

Or from the soul--an impulse to herselfI would give utterance in numerous verse.' ${ }^{1}$

We miss in Browning the vast expanse, the patient expectation, and the brooding peace. $\mathrm{He}$ is a dweller in the cities; and it is not the music of the winds and streams, nor the speaking pause of the silent mountains that we hear in his verse. He makes his music, scattering sounds from an instrument with many powers, and, like his own Abt Vogler, exultantly raising his palace of praise. But his instrument was of human device. And there are dissonances in his harmonies, discords that will hardly

${ }^{1}$ The Recluse. 
be resolved: for he is a Wagner among the poets. He went forth to seek contradictions, challenged the anomalous, outbraved scepticism, bade evil do its uttermost-'slid by semitones, sank to the minor,' before he found his restingplace again :

'The $\mathrm{C}$ major of this life.'

No two great poets differ more from one another than do Wordsworth and Browning.

Yet their mission and their testimony were the same. They triumphed by virtue of the same convictions. Browning's expression of the unity of man and nature in God was not so inevitable as Wordsworth's. It was more articulate and defined and punctuated; but it was less like the circumambient atmosphere, or the open eye of universal day. The unity of man and Nature for Wordsworth was temperamental, and it expressed itself in moods that were common to both; in the same gladness, love and peace: the motion of the Spirit within them was tranquil, like the deep breathing of a strong man asleep. But Browning's intuition of their unity was acquired. We feel that he 


\section{IDEALISM AS A PRACTICAL CREED}

had sat at the feet of modern science, even though he transfigured its lessons. We hear from him of the unity of the structure of visible things. He brooks no break in the ascent from lowest being to man's endowment; but he delights to mark its stages. The elements of physical and human nature are not fused, as they are in Wordsworth; and though God

\section{'Dwells in all}

From life's minute beginnings, up at last

To man-the consummation of this scheme

Of being, the completion of this sphere Of life,'

still the differences are marked and the distinction is kept inviolate.

It is interaction rather than interfusion that, on the whole, we find in Browning. Nature is a divine dwelling-place, and 'God joys therein,' but she is not one with the spiritual life of which she is the abode. She is rather the instrument of the universal soul and the external exhibition of its might and love, than its living embodiment. And the unity of nature with man is not always intrinsic and constitutive. 
'If two lives join, there is yet a scar, They are one and one with a shadowy third: One near one is too far.' 1

Nature is not spiritual as it were in her own right for Browning, as she was for Wordsworth. There were eighteenth-century orthodoxies in his mind which seemed to prevent him from lavishing the light of spirit upon natural things quite freely. Man and nature fitted one another, it is true-like the lute and the player's hand. Nature was made to be known, and mind was made to know her.

'Wherefore did I contrive for thee that ear Hungry for music, and direct thine eye To where I hold a seven-stringed instrument Unless I meant thee to beseech me play?'2

Still the natural world does not escape entirely from its naturalness. It needs the medium of man's mind in order to become emancipate from its latency. Nature is promise unfulfilled, and in pointing to man she points beyond herself. His

'Attributes had here and there

Been scattered o'er the visible world before, Asking to be combined, dim fragments meant

${ }^{1}$ By the Fireside.

${ }^{2}$ Two Camels. 


\section{IDEALISM AS A PRACTICAL CREED}

To be united in some wondrous whole, Imperfect qualities throughout creation, Suggesting some one creature yet to make,

Some point where all the scattered rays should meet Convergent in the faculties of man.'

Even with the help of man the emancipation is not complete. The calm of perfect knowledge, where spirit holds communion with itself and is to itself transparent, is not reached. There remains a strangeness to be overcome.

'No intuition, but the slow Uncertain fruit of an enhancing toil, Strengthened by love.'

And even the love, which for Browning always surpasses knowledge in its atoning powers, is

\section{' Not serenely pure}

But strong from weakness, like a chance-sown plant Which, cast on stubborn soil, puts forth changed buds, And softer stains, unknown in happier climes, Love which endures and doubts and is oppressed And cherished, suffering much and much sustained, And blind, oft-failing, yet believing love,

A half-enlightened, often chequered trust.'

Everywhere there is promise rather than full fruition, process rather than possession, arduous endeavour and aspiration without end, rather than the tranquil joys of what is all in all 
and at one with itself and adequate. There is ever a battle to be won and a negative to be overpowered; and in consequence there is stormful energy in Browning's assurance of his faith. There is no circumstance in which he will not bring it to the test, no strain to which he will not subject it. His very joy was to rim with silver-light the packed thunder-clouds of man's most dreaded fate.

'Set down my name, Sir,' said the Valiant Man whom Christian saw in the Interpreter's house. 'The which when he had done, he saw the Man draw his Sword and put an Helmet upon his Head, and rush toward the door upon the Armed Men, who laid upon him with deadly force; but the Man, not at all discouraged, fell to cutting and hacking most fiercely; so, after he had received and given many wounds to those that attempted to keep him out, he cut his way through them all, and pressed forward into the Palace; at which there was a pleasant voice heard from those that were within, even of those that walked upon the top of the Palace, saying: 
'Come in, come in,

Eternal Glory thou shalt win.'

So he went in, and was clothed with Garments as they.'

This is the parable of Browning's poetic life. The ardour of adventure in an unconquered land flashes from his soul like sunshine from armour. But Wordsworth was one of the native inhabitants of the land of Beulah, 'whose Air was very sweet and pleasant. Here he heard continually the singing of Birds, and saw every day the Flowers appear in the Earth, and heard the voice of the Turtle in the Land. In this country the sun shineth every day; wherefore this was beyond the Valley of the Shadow of Death, and also out of the reach of Giant Despair; neither could they from this place so much as see Doubting Castle.' ${ }^{1}$

The tranquil gladness of contemplative fruition, as of one who had left the gloom behind and was 'stepping westward' was Wordsworth's.

'I liked the greeting; 't was a sound Of something without place or bound; And seemed to give me spiritual right To travel through that region bright.'

${ }^{1}$ The Pilgrim's Progress. 


\section{WORDSWOR'TH AND BROWNING 181}

It was the tumultuous joy of a strenuous warfare in a stubborn land, the sense of moving onwards, with a conquering host that numbered the elements of heaven and earth, which was Browning's. Still their faith in the nature of things and in the security of the enduring purpose that moved within them was the same. And it was never shaken into frailty: not for Wordsworth by the maddest orgies of the French Revolution; nor for Browning by his dark explorations amongst the sunless recesses of sordid and sinful souls. It is true that the world appeared for Browning as

'A dread machinery of sin and sorrow';

but it was meant 'to evolve the moral qualities of man.'

'Winds blow, and waters roll

Strength to the brave, and Power and Deity.'

And the gain was worth the cost.

In one respect only did Browning's faith show itself craven-hearted, at least as compared with the dawning Idealism of his times. He had inherited from the unintentional Agnosticism of the schools of his early years a dis- 


\section{IDEALISM AS A PRACTICAL CREED}

trust of human knowledge which, consistently held, should have supplanted his Idealism and destroyed his faith. For this theory did not merely teach-what no one will deny-that human knowledge was incomplete, like everything else that is human, and fell short of perfection in every way. It represented knowledge as defective in kind, as failing abruptly and finally; for it never comprehended what was real, nor ever escaped, in great things or in small, from dealing in mere appearances and false shows.

'To know of, think about-

Is all man's sum of faculty effects

When exercised on earth's least atom, Son!

What is, what was, what may such atom be?

No answer!' 1

Spiritual ambition, limitless in all else, was rebuked in knowledge.

'Beyond thee lies the infinite--

Back to thy circumscription.'

We know neither God nor the world: and our ignorance of these is matched by our ignorance of moral matters.

${ }^{1}$ A Bean-Stripe. 


\section{WORDSWORTH AND BROWNING 183}

'Ignorance o'erwraps his moral sense,

Winds him about, relaxing, as it wraps,

So much and no more than lets through perhaps

The murmured knowledge-'Ignorance exists.'

Subjectivity, solipsism, relativity, limitation, inconsistency, insecurity-every defect in knowledge which philosophy could discover or invent is asserted and reiterated by Browning, especially in his later years, when his poetic inspiration waned, stricken by the blight of dialectical argumentation.

'My curls were crowned

In youth with knowledge,-off, alas, crown slipped

Next moment, pushed by better knowledge still

Which nowise proved more constant: gain, to-day,

Was toppling loss to-morrow, lay at last

-Knowledge, the golden?-lacquered ignorance !'1

In all things worthy save in knowledge, progress was the distinctive note of man: progress towards, nay within, an infinite ideal ; for his life was divinely sustained, and the might of God was in him. In knowledge man was left to himself and there was no progress: for what progress could there be, what less or more of truth, in a realm peopled all with phantoms?

${ }^{1}$ A Pillar at Sebzevar. 


\section{IDEALISM AS A PRACTICAL CREED}

There is fatal inconsistency here, which no dialectical skill on the part of the poet-and he tries many methods-could finally overcome. He spares no endeavour to turn the failure of knowledge to account; but the hurt was never healed. In itself knowledge was lacquer and not gold; it was useful only as means.

'As gain-mistrust it! Not as means to gain: Lacquer we learn by.

... Knowledge means

Ever-renewed assurance by defeat

That victory is somehow still to reach,

But love is victory, the prize itself:

Love-trust to! Be rewarded for the trust

In trust's mere act. In love success is sure,

Attainment-no delusion, whatsoe'er

The prize be.'

And when Browning comes back to 'Love,' he speaks 'with the great mouth of the gods.' 'Taking his work as a whole, it is scarcely possible to deny that Love is at once the supreme motive of his art, and the principle upon which his moral and religious doctrine rests. $\mathrm{He}$ is always strong and convincing when he is dealing with this theme. It was evidently the light of his life; it gave him courage to face the evils 


\section{WORDSWOR'TH AND BROWNING 185}

of the world, and the power as an artist 'to contrive his music from its moans.' It plays, in his philosophy, the part that 'Reason' filled for Hegel, or the 'Blind Will' for Schopenhauer ; and he is as fearless as they are in reducing all phenomena into forms of the activity of his first principle. Love not only gave him firm footing amid the wash and welter of the present world, where time spins fast, life fleets and all is change, but it made him look forward with joy 'to the immortal course.' For all the universe seemed to him love-woven, all life is but treading 'the love-way,' and no wanderer can finally lose it.' 'The way-faring men, though fools, shall not err therein.'

It is altogether beyond the scope of these lectures to follow his exposition of this principle, from which he drew his theory of life and of all its setting: how love is the sublimest conception attainable by man-the one way in which he dares define his God; how a life inspired by love is the most perfect form of

${ }^{1}$ See the Lecturer's Browning as a Philosophical and Religious Teacher. MacLehose, Glasgow. 


\section{IDEALISM AS A PRACTICAL CREED}

goodness, and is therefore at once man's absolute ideal of conduct, and alone the object worthy of his worship, worthier far than any exhibition of power :

'For the loving worm within its clod,

Were diviner than a loveless God,

Amid his worlds, I will dare to say.' 1

Love is in its nature so pure, 'so perfect in whiteness, that it will not take pollution.'

In the corruptest hearts, amidst the worst sensuality, it is still a power divine,

'Incompatible

With falsehood-purifies, assimilates

All other passions to itself.' ${ }^{2}$

'Ne'er wrong yourself so far as quote the world And say, love can go unrequited here!

You will have blessed him to his whole life's endLow passions hindered, baser cares kept back, All goodness cherished.' ${ }^{3}$

To love, he tells us once and again, is the supreme, the sole object of man's life, the one lesson he is set to learn on earth : and that once learnt, in what way matters little, 'it leaves completion in the soul.'

${ }^{1}$ Christmas Eve.

${ }^{2}$ Colombo's Birthday. ${ }^{3}$ Ibid. 


\section{WORDSWORTH AND BROWNING 187}

'There is no good of life but love-but love!

What else looks good, is some shade flung from love, Love gilds it, gives it worth.' ${ }^{1}$

As Wordsworth extended the domain of Spirit over the whole realm of created being, so does Browning teach the omnipresence of Love. There is no fact without its purpose, no event broken loose from the universal order,

'No detail but in place allotted it, was prime And perfect' ; ${ }^{2}$

and love is the soul of the purpose, and the source and security of the unfailing order. Seen in the light of love, Nature ceases to be merely natural. Matter and 'life's minute beginnings' are more than they seem; for the scheme of love does not begin with man: he is its consummation. And Browning delights to set forth the stages of the ascent; for he is a true believer in Evolution. "The secret of the world was mine,' he says, revealing himself in Paracelsus.

'I knew. I felt . . .

What God is, what we are,

What life is-how God tastes an infinite joy

In infinite ways-one everlasting bliss,
${ }^{1}$ In a Balcony.
${ }^{2}$ Fifine at the Fair. 


\section{IDEALISM AS A PRACTICAL CREED}

From whom all being emanates, all power Proceeds; in whom is life for evermore, Yet whom existence in its lowest form Includes.'

He goes back to the beginning of things and follows the ascending steps from chaos to order, from matter to physical life, from physical life to the rational and loving life of man, from these to God, who stands revealed in all the process. 'The centre-fire heaves underneath the earth'; 'the wrath sea's waves are edged with foam'; 'strange groups of young volcanoes come up, cyclops-like, staring together with their eyes on flame'; 'the spring wind, like a dancing psaltress, passes over the wintry earth, to waken it'; 'the shining dorrs are busy, beetles run along the furrows, ants make their ado, birds fly in merry flocks';

\section{'Savage creatures seek}

Their loves in wood and plain-and God renews His ancient rapture.'

\section{'And all lead up higher,}

All shape out dimly the superior race,

The heir of hopes too fair to turn out false,

And man appears at last.'

\section{'All tended to mankind}

And, man produced, all has its end thus far. 
But the true end is not yet, the Spiritual development is still to come.

'In completed man begins anew

A tendency to God. Prognostics told

Man's near approach: so in man's self arise

August anticipations, symbols, types

Of a dim splendour ever on before

In that eternal circle life pursues.'

To Paracelsus, proud at first only of the intellect and forgetful of the rôle of love, all this seemed but the exhibition of Power. His attitude was like that of the natural man.

'I gazed on power till I grew blind.

Power; I could not take my eyes from that.

And 'power' left weakness unexplained.

'I saw no use in the past: only a scene

Of degradation, ugliness and tears,

The record of disgraces best forgotten,

A sullen page in human chronicles

Fit to erase.'

But he learnt his own deep error.

'Love's undoing

Taught me the worth of love in man's estate.

... Love preceding

Power, and with much power, always much more love.

Love still too straitened in its present means,

And earnest for new power to set love free.'

Here, then, in the principle of love, was the 


\section{IDEALISM AS A PRACTICAL CREED}

primal motive of the whole movement; and in its light was all made plain, even 'the wear and waste of faculties.' Love, having been made wise in his own heart, was able

'To trace love's faint beginnings in mankind, To know even hate is but a mask of love's, To see a good in evil, and a hope In ill-success; to sympathize, be proud Of their half-reasonings, faint aspirings, dim Struggles for truth, their poorest fallacies, Their prejudice and fears and cares and doubts; All with a touch of nobleness, despite Their error, upward tending all, though weak; Like plants in mines which never saw the sun, But dream of him, and guess where he may be, And do their best to climb and get to him.'

Many poets-may I not say all poets?-have sung of love, some of them perhaps with more exquisite utterance and lighter grace than Browning. But there is a respect in which Browning stands alone. $\mathrm{He}$ has given to love a moral significance, a place and power amongst the elemental conditions of man's nature and destiny; and he has given it a religious and metaphysical depth of meaning, which, I believe, are without example in any other poet. By means of Love, daring to believe the Nazarene 
teacher and to adopt as the light of all his seeing the conception which makes Christianity sublime and, probably, the ultimate religion of mankind, he identified the human with the divine, and found in love the atonement of the world. Here lay the secret of his power and all his hope.

The Idealism of Love brought it about that, contemplating the fate of man, 'he never missed footing in the maze,' 'nor feared the dark at all,' nor grew faint for any adventure.

\section{'If I stoop}

Into a dark tremendous sea of cloud

It is but for a time: I press God's lamp

Close to my breast; its splendour, soon or late,

Will pierce the gloom: I shall emerge one day.' 1

Nor do the after-lives bring either doubt or fear-for Browning conceives of 'life after life in unlimited series.'

Summoning age to grant the harvest of youth in this life,

'Life's struggle having so far reached its term,

Thence shall I pass, approved

A man, for aye removed

From the developed brute: a god though in the germ.

${ }^{1}$ Paracelsus. 


\section{IDEALISM AS A PRACTICAL CREED}

\section{And I shall thereupon}

Take rest, ere I be gone

Once more on my adventure, brave and new :

Fearless and unperplexed

When I wage battle next,

What weapons to select, what armour to endue.'

A faith like Browning's and Wordsworth's is a philosophy of life which, if true, we would purchase at a great price. But had they the right to it? 


\section{VI.}

\section{THE CALL OF THE MODERN AGE.}

How to test the statements as to the vital elements of the modern creed: The Argument from Desire never convincing-only Reason can prove or disprove: The demand we must make on the Idealists, and their counter-demand on us: Idealistic Solutions have value only where experience is found to be discrepant: The present times offer to Idealism the opportunity which it requires, for modern life has outgrown the creeds: Economic and social changes: The irrelevancy of the Individualism of the past and the fatuity of the Socialism of the present: The need of Ethical change, before the conditions of a complete democracy can be sustained: The attitude of the better spirits to religion: The demand upon the Idealists altogether just: Can the Idealists meet it? 


$$
\text { . }
$$




\section{VI.}

\section{THE CALL OF THE MODERN AGE.}

I HAvE been trying to show, thus far, that the conception of the unity and spiritual nature of things dominates the poetry and philosophy of our day. The same conception is implicit in the harmony of individual and social ends, which is the condition of true or positive freedom, and the promise of which seems to be present in our practical life.

Now, I should have no ground of complaint if you refused either to assent to, or to dissent from, these wide generalizations. It is not easy to discern the tendencies which rule in an age that is beyond all comparison rich in the variety of its interests. Besides, we live amongst them; and we are always least conscious of those tendencies whose sway is most constant and 


\section{IDEALISM AS A PRACTICAL CREED}

universal, and whose possession of us is most complete. When they have become the objects of our reflective thought they are usually on the point of losing our allegiance or of being merged in wider principles. Comprehension implies mastery, whether in the region of natural or of spiritual matters.

There is one way, however, in which the correctness of our generalizations may be tested. In any experience, those conceptions are essential whose denial would loosen its continuity, and leave it a chaos of unreconciled impressions. In order, therefore, to discover whether the conception indicated is really vital to the science, the poetry, the philosophy, or the religious and social life of our times, we have only to ask what would remain of them if it were discredited. Supposing, for instance, the principle of Evolution were found to be false in its application to natural phenomena, or to the history of human institutions, what would the natural or the historical sciences retain beyond a mass of contingent particulars waiting to be colligated? Or supposing the conception 
of the real as spiritual were to fail the Idealists, what message would they still have for mankind? Or, lastly, supposing that Wordsworth had discovered that 'Nature is in reality trivial and all her pomp tinsel; that neither in her nor in the mind of man is there any magnitude of purpose or depth of soul, but only little bustling passions which exclude all thought, how much of his poetic inspiration would have survived?

Browning has left us in no doubt. He has told us how the failure, even in one instance, of the principle on which he had rested his life would have destroyed it.

' Of absolute and irretrievable And all-subduing black-black's soul of black Beyond white's power to disintensifyOf that I saw no sample: such may wreck My life and ruin my philosophy To-morrow.'

There is no better way of discovering what elements amongst our creeds are really vital to us than that of asking what we would do if they broke down. When the disciples were asked, 'Will ye also go away?' Simon Peter 


\section{IDEALISM AS A PRACTICAL CREED}

answered, 'To whom shall we go? Thou hast the words of eternal life.' The loss of dominant principles is the loss of life's significance.

Tried by this test, I have little doubt that the conceptions we have indicated will be admitted to be essentially constitutive of the experience of our day as expressed in its greatest poetic, philosophic and religious literature; and, even also, though less manifestly, in its ethical and social life.

But this does not show that the conceptions are true, nor even that they have practical import and real value. In one respect, indeed, the conception of the unity and spiritual nature of reality has very great value; even, though it should prove-as Comte thought-to be only the departing shadow of a religious superstition lingering in an 'enlightened age.' It has been an incomparable anodyne to a suffering world; and it will always be so to those men who can entertain it seriously. Nevertheless we cannot conclude from this circumstance that the conception is true. It may be only the needful nutriment of the childhood of mankind, the 
THE CALL OF THE MODERN AGE 199 noble-lie that leads to truth. The 'argument from desire' - namely, that those ideas must be valid which meet man's deepest wants-is not convincing in any of its forms ; for it rests upon optimistic presuppositions which have themselves to be verified. Desire is as apt to err as reason : indeed, desire, though based on natural wants, is itself the result of our rational construction of our wants and of the objects which we think will satisfy them. There is, in fact, no way of testing any truth except by reason. The appeal to experience, or to 'the heart,' is still an appeal to reason, and only reason can read the results. For Reason is no abstract faculty, but a name for the whole man, who is himself the living totality of his own experience, when engaged upon discerning the true and false.

In short, this rational test cannot be avoided. Idealism may find it difficult to satisfy the demands of the critical intelligence, and the failure to do so may bring grave consequences; but I must frankly confess that the demands are fair.

It may be objected, however, that while these 


\section{IDEALISM AS A PRACTICAL CREED}

demands may be justly made upon the philosopher, they cannot be pressed upon the poet. Philosophy must retain its rights on scientific sufferance, but poetry justifies itself in other ways. 'It has a truth of its own, a truth which we feel, though from the scientific point of view we may admit it to be an illusion.' 'The highest poetry of our time-that in which the most serious and select spirits find their fooddepends chiefly for its interest on what has been well called 'the application of ideas to life'; but these ideas are welcomed by the multitude of the educated, not because they are regarded as demonstrable, but because they are presented in the rapt unreasoned form of poetic utterance, and do not profess to do more than represent a mood of the individual poet.' 1

I admit the justice of the objection, so far as it implies that poetry is not meant to be demonstrative, either in form or spirit. Nevertheless poetry may convince, and do so, for some minds, all the more effectively because it makes no logical pretensions. It may organize truth, ${ }^{1}$ See Green's Prolegomena to Ethics, Introduction. 


\section{THE CALL OF THE MODERN AGE 201}

even though it does not expose the rational filaments which colligate its elements. And when it deals with the graver issues of life, as the highest poetry does, it may both exercise this synthetic power and be faithful to the medium within which it works. When Fancy's fingers touch the strings we do not look for 'truth,' but for pure aesthetic pleasure; but for the larger music we look to Imagination, and its realities are never shows. 'Poetry,' says Wordsworth, 'is the image of Man and Nature.' 'Its object is truth; not individual and local, but general and operative : truth which is its own testimony, which gives confidence and competence to the tribunal to which it appeals, and receives them from the same tribunal.' Without in the least confusing the methods of the poet with those of the philosopher, seeking merely to be sensitive and responsive to the charm of his highest imaginative powers, we may still feel that his ideas apply to life, and come to him, as indeed we do, asking grave questions.

We shall even miss his poetic significance if we approach him in a lighter mood; for much 


\section{IDEALISM AS A PRACTICAL CREED}

of the power of conceptions lies in the way in which they are entertained. No man, whether he be poet or philosopher, has ever helped the world with what is to himself a 'may-be' or 'perhaps.' 'Every great poet .. . before he can be thoroughly enjoyed has to call forth and communicate power,' says Wordsworth. But his message has power only when it is freighted with his own personality. Nay, there is more at stake in his mission than his own personality. He must appear as the emissary of a higher authority, be carried along by thoughts he can not control, like a ship whose sails are filled with the winds of the open ocean. Every prophet, whatever his garb, speaks in the name of the nature of things, and, being sent on a royal mission, he prefaces his words with a "Thus saith the Lord.'

' Be mine to follow with no timid step Where Knowledge leads me'

is Wordsworth's inauguratory prayer.

$$
\text { 'It shall be my pride }
$$

That I have dared to tread this holy ground Speaking no dreams, but things oracular.'

There is indomitable firmness in this poet's tread, 
'IHE CALL OF THE MODERN AGE 203

as of one who walks, not in the realm of fancy, but among objects that endure, and in the light of open day. And, beyond doubt, this is one of the secrets of his power.

We do well in demanding aesthetic enjoyment of the poets; but we do neither them nor ourselves justice unless we demand much more.

They are not merely sublime confectioners. They have a higher calling. We owe them deeper reverence than the attitude of mind which neither believes nor doubts:

'The easy acquiescence of mankind In matters no-wise worth dispute.'

Great truths, however presented, can find no lodgement in a frivolous mind. Not to every eye is given the vision of the Holy Grail. 'Unto the pure all things are pure; but unto them that are defiled and unbelieving is nothing pure.' To the worldly spirit, or a mind confused 'with the busy dance of things that pass,' the doctrine of a universal love which redeems the actions of men from sordidity, and engenders a charity that never fails and a beneficence which grows not weary, is but the sound of a tinkling 


\section{IDEALISM AS A PRACTICAL CREED}

cymbal. Browning may find the doctrine fill the universe with light, but they neither need nor trust it. 'The light shineth in darkness, and the darkness comprehendeth it not.' I venture to say that the main obstacle to the serious acceptance of the higher Idealism may be in ourselves.

In any case, when we demand proof of his doctrines, the Idealist is entitled to make a counter-demand upon ourselves. He can not ask for a credulous mind, but he must ask for the earnestly enquiring spirit. Philosophy has no meaning for men at ease: its synthesis has no vitality except where experience is baffled by its own discrepancies. And there is one character that never fails to mark every form of Idealism, whether it be that of religion or poetry or philosophy, and which distinguishes it from every form of 'Naturalism.' It does not appeal, and its doctrines have no cogency to any one, until other helps have failed. Religion has been called a sense of infinite dependence, and it always is a refuge from the consciousness of guilt and weakness. Philosophical Idealism, in like manner, is 


\section{THE CALL OF THE MODERN AGE 205}

a recoil from the endless negation of the finite. They are both, in different ways, the awakened soul's last resort. Man does not begin with them; for it is a law of his sensuous-rational nature that the ends he first desires are finite. The wants which he first feels are animal wants, and he seeks his good among things which do not endure. When he first finds himself he has everything to acquire, even his own spiritual nature. He is in a far country, and has joined himself to the citizens thereof, and he would fain satisfy himself with husks; till, at last, the hunger of his soul awakens, and he remembers his Father's house, where even 'the hired servants have bread enough and to spare.'

In thus maintaining that spiritual things must be spiritually discerned, and that the natural man receiveth them not, 'for they are foolishness unto him,' I am far from wishing to suggest the existence in these matters of unique or esoteric conditions : or to assert a different law in ethical and religious experience from that of ordinary experience. I wish, rather, to show that the law is the same. If you cannot prove 


\section{IDEALISM AS A PRACTICAL CREED}

the truth of the things of the spirit to the natural man, no more can you prove or disprove a complex physical truth to an uneducated mind. A little child can make nothing of an advanced mathematical formula. In all matters, both theoretical and practical, we must know that there is a problem, and understand something of its terms, if we are to be either satisfied or dissatisfied with the solution that is offered. In fact any answer given to problems, whether they be intellectual, or moral, or religious, or even aesthetic, must lie in the terms of the problems themselves; for the answer consists in making the congruence or incongruence of the terms clear. Hence the first condition in all education is to stimulate the sense of difficulties to be solved, that is, to arouse enquiry; and there is no way of stimulating enquiry so efficient as that of bringing apparent contradictions into light. Then the mind's most imperious need makes itself felt, namely that of maintaining the unity of its experience, or, in other words, its sanity. When, therefore, we find Socrates making it his mission to convict the Athenians of ignorance in 


\section{THE CALL OF THE MODERN AGE 207}

moral matters, or the Christian teacher convicting the world of sin and calling it to repentance, they are making use of a deep psychological law everywhere applicable. There is no meaning in unity except amongst differences ; no possibility of proof except where there is a problem; and no sense of a problem except where discrepancies are felt. The deep slumber of sense has to be broken, if the wants of man's rational and spiritual nature are to be satisfied. We need ' the sting that bids nor sit nor stand but go.' 'He hath filled the hungry with good things: and the rich he hath sent empty away.'

This, then, is the contribution which they must bring to the Idealist who demand of him some proof of the truth and value of his conceptions. They must come to him, if not with a problem formulated, yet with the sense of an experience which is inconsistent with itself and demanding reconcilement.

But art, philosophy and religion are, as we have already seen, paramount witnesses to the harmony of their object. Their unique function is to reveal unity in difference, whether that 


\section{IDEALISM AS A PRACTICAL CREED}

unity be a law of thought, or a principle of life, or that of the less definable but not less real sense of beauty. And it is on this account that in all ages of the world we find men approach them, saying: 'My purposes have failed; my life is broken and discrepant; I come to be made whole.'

Now, it is precisely because this condition is being fulfilled in our own day that Idealism, in one or other of its forms, promises to be of supreme importance in times to come, and the question of the validity of its deliverances to be seriously asked. In whatever direction I look abroad, whether it be upon the moral, or social, or religious life, I find that its self-contentment is broken. The hedonism in morals, and the individualism in politics, which satisfied the world from Bentham to Mill, inspiring much most beneficent legislation, have become utterly inadequate to our times. The deism to which the natural world was so secular and the things of spirit so simple and compassable is quite discredited. We know that a religious theory which places God beyond the realm of finite 


\section{THE CALL OF THE MODERN AGE 209}

being is without any defence against the assaults of the Agnostic and Sceptic. If man is to find God he must find Him in the world he knows, as its very substance and essential being. But what substitutes have we for the dapper creeds of the past? What, besides the consciousness that man's ethical nature is deep, and that duty means more than pleasure; that society is complex, and that so far from being an external concatenation of independent individualities, its filaments are organic and its roots penetrate to the inner soul of all its members; that God is immanent in the world, and that His immanence in a world so stricken with evil is hard to understand? The early stars have set, and the dawn has not appeared; and we sit in deep darkness.

'The ignoble confidence,

Cowardly hardihood, that dulls and damps,'

rules no more. 'The torpor of assurance has been shaken from our creeds.' We are driven onwards towards a more vital intercourse with spiritual conceptions; and the Idealism of the poets and philosophers is finding its opportunity.

I shall not apologize for dwelling at some 


\section{IDEALISM AS A PRAC'IICAL CREED}

length on this characteristic of our times, for it concerns us. I must try to show how our problem has grown under our hands, and how the familiar formulae fail.

First, then, as to the domain of ethics and sociology, and the manner in which the changed conditions of our outer life demand a different response both of the mind and heart.

The egoistic life that would fain be solitary, being narrowly bent upon its own exclusive good, is being gradually constrained to enlarge its outlook. Even if its ends remain unchanged and the selfishness of its motives are untouched, it is being compelled to employ other means, for it is being driven to recognize that men's lives are entangled together. There is no sphere where egoistic conditions are more dominant, or where mutual resistance and competition are more obviously the law, than the sphere of economics. For it is the nature of material as distinguished from spiritual goods that they cannot be distributed without lessening every one's share. Nevertheless, even in this sphere, co-operation is being revealed as the deeper law, 


\section{'THE CALL OF THE MODERN AGE 211}

and the good of each to be the good of all. The isolated endeavour is being convicted of feebleness. However much they may desire it, no individual and no nation can live for itself alone. Reluctantly, but surely, the whole world is becoming one mart. The ebb and flow of commercial and industrial prosperity travel round the world, and they creep into the most quiet creek and remote inlet. All the civilized, or productive, peoples of the world have one economic destiny. There is less chance than at any other time for the nation whose aims are exclusive and whose means are narrow. The nation which achieves most is that whose services to the world are greatest, for true prosperity takes a wide compass round. ${ }^{1}$

1I do not want to meddle with the conditions under which you think fit to trade with your neighbours. There may be reasons applicable to a young country for fostering its enterprises under an artificial regime. Present economic loss may have to be sustained for the sake of future economic gain. But a policy of exclusion has in the last resort to reckon with the nature of things, which is apt to win ; and nations which adopt it will have to learn, perhaps through much suffering, that those who desire to sell must buy, and those who would be rewarded of the world must be willing to be of service to the world. 


\section{IDEALISM AS A PRACTICAL CREED}

That these deep economic changes must bring others in their train is obvious. Interchange of commodities and identity of economic destiny bring interchanges of another kind and a sense of mutual responsibility in other matters. Social and political impulses travel from state to state, and the nations inspire one another to good ends and to bad. What more convincing evidence can we have of this than the tragic emulation of powerful states in military equipment? Or what is more certain than that it must in the last resort stultify itself? Surely, the time is coming when the over-burdened and longsuffering peoples shall inaugurate a more massive diplomacy than that of the diplomats, and make possible another way of arbitrament than that of

- violence. In short, changed outward circumstances compel reflexion; the new world demands the new response. Our ideas must be enlarged and our motives become more human.

There is the same movement towards solidarity within the members of the same society, bringing with it the same demand for new interpreting conceptions and new ideals. Men 


\section{THE CALL OF THE MODERN AGE 213}

whose interests are in the same objects, and who stand in a direct competitive relation with one another, worker with worker, salesman with salesman, capitalist with capitalist, combine together in these days-a fact which an individualistic theory could never have predicted and cannot explain; for from that point of view no combination is more unnatural. But, by the slow growth of circumstance and in spite of theory, it is seen that there is practically no purpose which a man can now achieve in isolation. Whether he desires to hold his own in the struggle for economic justice, or to further any form of social good, he must unite with others whose purposes are similar. The various social interests are organized, whether they be industrial, or commercial, or educational, or charitable; and society from top to bottom is striated and stratified into classes. The conditions of the individual's activities have thus been changed, and even if his purposes remain the same he must seek to attain them in another way. He is now one of a class, and it is in union with it that he fails or prospers: his fate 


\section{IDEALISM AS A PRAC'TICAL CREED}

is united with that of others in similar circumstances to his own.

You may say that the change has only enlarged the scope of selfishness, and placed in the hands of a more remorseless egoism weapons which are more powerful. And it is true that all things which multiply a man's strength by uniting him with his fellows increases his power for evil as well as good. New conditions always bring new opportunities for both right and wrong, and the higher we climb the deeper the fall. All the same the movement is onwards and upwards. The sphere of responsibility for the individual is widened, and even fidelity confined to one's own class is so far better than loyalty to one's self alone.

But these classes and interests collide: sometimes with such momentum as to arrest the industries and imperil the stability of the State. True! but in this case also new risks imply new opportunities, and services, not required before, are called forth. Men of wider outlook, who recognize in the State the palladium of all the interests, see in these collisions a demand for 


\section{THE CALL OF THE MODERN AGE 215}

controlling the colliding forces. As individuals who deem themselves wronged, or their rights denied, are no longer permitted to be judges in their own cause, and executors of their own decisions, so the time is coming when the State shall sit in judgment upon these wider controversies. Methods of violence shall give way to methods of peace; he who suffers most or has least endurance will not on that account be held to be wrong; and the cause which is most just shall be deemed the stronger.

One way or another, under the pressure of blind forces blindly obeyed, a condition of affairs is arising in which the individual's life is known to be more deeply implicated in the life of his fellows, and in the well-being of the whole community of which he is a member. The State grasps his life more closely and on more sides, and he is more variously, if not in the last resort more deeply, involved in its welfare than at other periods-for at all times the State is ultimately all in all for its citizens. The duties of the Modern State being enlarged and its functions being more numerous-which is only 


\section{IDEALISM AS A PRACTICAL CREED}

another way of saying that its opportunities of service to its members are greater-the risks of bad government are also greater, and the damage which ignorance, or selfishness bring, whether on the part of the rulers or the ruled.

But if the risks are greater, so also are the opportunities. There are greater forces in the field, and they are more beneficent, to him who can comprehend and use them. The best mind of the people is more imperiously driven to more earnest dealing with the conditions of social welfare. Government by ignorance or party passion, indifference to the State, and a spirit of slack citizenship, seeing that they bring such intimate perils, are being recognized as public wrongs. Our statesmanship will acquire gravity: the State will acquire a new sacredness and 'be looked upon with other reverence.' It will be known as a partnership in which the citizen has staked not only his worldly prosperity, but his personality. We shall think of it after the great way of Edmund Burke. 'It is a partnership in all science; a partnership in all art; a partnership in every virtue and in all perfection. 


\section{THE CALL OF THE MODERN AGE 217}

As the ends of such a partnership cannot be obtained in many generations, it becomes a partnership not only between those who are living, but between those who are living, those who are dead, and those who are to be born.' ${ }^{1}$

To those who are worthy of it citizenship in such a state will appear to be no mean privilege. And the yoke in so great a service will seem to them easy ; for the greatness of a cause lightens the burdens it imposes. It converts responsibilities into a valued trust, and gives to the individual life a noble content and the best of destinies.

Thus is the selfishness of humanity being rebuked and its folly exposed. By the very stress and strain of circumstance man is being moralized; and the world is in one conspiracy against his meanness. Who then can say that the ancient rubrics hold, or that in the domain of either economics, or morals, or social life, or politics, the negative freedom of the past, with its 'Let things be' and 'Do not interfere,' can furnish us with the guidance which we need?

${ }^{1}$ Burke's Reflections on the Revolution in France. 


\section{IDEALISM AS A PRACTICAL CREED}

Are we not compelled, seeing that the capacity of social forces for good and for evil has been thus expanded, and the life of every individual is more widely interfused with the general welfare, to seek some better way of comprehending them than is furnished by the abstract individualism of the past?

And is the Socialism of the present day anything except its complementary error? Is there any reflective person who would for a moment maintain that the new economic and social conditions which those who call themselves Socialists seek have any virile purposefulness? Verily! poverty of imagination is deep poverty. I have sometimes wondered who is most stricken with it, whether it be those who advocate, or those who fear, the impossible schemes of the more ambitious Socialism. Can you conceive a people, like ours at home, sitting, some of them in hope and some in fear, of a levelling socialism while it is unable to 'reform the House of Lords'; or trembling, some of them with eagerness and some with anxiety, lest private property should be annulled, while its sense of the 
rights of private property is so deep that twenty years seem too short a notice for the State to annul licences which are annual?

Nevertheless, impossible and even absurd as socialistic schemes generally are, it is Socialism in some form or other alone that evinces any consciousness of the deepened solidarity of modern citizenship, or dreams of a constructive statesmanship that will fit its exigencies. Its gravest error of all probably is that its attention has so far been confined to impracticable changes in economic conditions; and that there is little consciousness of the need of the ethical change which would make these conditions tolerable. It is not seen that a socialised State brought upon a people morally unprepared would be the deepest calamity any nation could be called upon to meet. No State requires governors so enlightened or so unselfish as the State in which all are governors. A genuine democracy demands the highest civic virtues, with the alternative of the deepest and most irremediable civic tragedy; for the actions of the citizens of such a State are scanned only by themselves, 


\section{IDEALISM AS A PRACTICAL CREED}

and the only critics their deeds can have are the consequences which follow from them.

Thus, then, the expansion of the range of ethical responsibility; the greater complexity of the modern State; the deeper implication of the lives of the individual citizens therein; the increase in the variety of its functions, and therefore in its capacity either for mischief or for good; its more democratic character, which subjects it only to its own caprice and with the removal of external restraints makes inner restraint imperative ; the irrelevance of the Individualism of the past to its more highly organic character, and the impractical and un-ethical character of the Socialism of the present-all these things taken together constitute a reason, which is also a necessity, for the more earnest questioning of our ideals of life.

Nor is it difficult to believe that the only ideals which can sustain, and be sustained by, the new conditions of greater social solidarity, are those which inspire that social solidarity which leaves its members free. Nothing can save the highly-organized and many-functioned States of 


\section{THE CALL OF THE MODERN AGE 221}

the future from being the most remorseless and ubiquitous of tyrannies except the consciousness of fellowship and brotherhood amongst its members and free devotion to its welfare. But this is only to say that the Idealism of Love, of which the poets speak, and the consciousness of unity amidst the deepest differences,-namely, the differences which separate one rational individual from the other, to which the philosophers bear witness,-furnish the only adequate principle of conduct.

I am aware that their Idealism stands in need of articulation. Its conceptions are general, and they must be defined and particularized into detailed maxims of personal conduct and into specific enactments of the State. The hedonism of the last period in our history had its Bentham, and he deduced from its most inadequate ethical content 'principles of legislation' whose practical value in the hands of statesmen proved inestimable. The social philosophy which can make an analogous use of the far deeper Ethics of Idealism has not as yet appeared, except in merest outline; statesmen do not strive to legis- 


\section{IDEALISM AS A PRACTICAL CREED}

late in its light as they did in the light of universalistic hedonism; and no one has formed even a proximately adequate conception of a concrete State based upon its principles. And since the polity which is latent in its ideals has not been devised, its ideals have not been put to the test of facts. But it is such a practical test that hypotheses demand, because it is only in the context of circumstance that objects reveal their nature. Nor, I believe, is there rational doubt that they will stand the test. Can you question the economic strength, the unity of purpose, the stability, the power in all worthy ways of a nation which, instead of stumbling blindly along a path unknown, and being driven hither and thither by the gusts of private and political passions, shall be inspired and guided by such ideals, and shall set itself resolutely, by methods well-weighed, to realize them in its deeds? Until we bring it to this practical test, we shall not be in vital earnest with our Idealism, and it is on that account that neither proof nor disproof is as yet possible. Its conceptions may be true; poets and philosophers who have 


\section{THE CALL OF THE MODERN AGE 223}

lived in their atmosphere have found them satisfying. But if, for us, they are still in the realm of conjectures, it is because we have left them there, instead of bringing them to the proof of life.

I turn now, for a moment, to indicate the same movement in the realm of religion: for there, too, 'the torpor of assurance has been shaken from the creeds,' and new conditions have brought new demands. At 'Home,' beyond all doubt, the spirit of enquiry is more earnest than it was in the past. There is less flippancy amongst both believers and sceptics; neither the assent to, nor the dissent from, the creeds is so shallow. More fundamental issues have been raised. The assaults, not of science, but of science which in the middle of last century was by an illegitimate extension perverted into a materialistic view of the world; the application of the methods of literary and historical criticism to the sacred books; the hypothesis of the continuity of man with nature and of the uniformity and universality of the deeper laws of the development of the human race, and of the unity of 


\section{IDEALISM AS A PRACTICAL CREED}

its history; the impatience of dogmatism and the repudiation of any authority that would browbeat private judgment; democracy in the domain of the creeds as well as in that of politics-all these forces have conspired together to bring the central tenets of religious faith to a test not for a moment to be paralleled for its severity in any previous age. Moreover, weapons once effective for their defence are now corroding with rust. Not long ago enquiry could be abashed and silenced. It was only necessary to point either to the authority of a Church or to the infallibility of a Book; the voice of the private conscience was hushed; reason was expelled from the court as an incompetent witness. But the prejudice against reason is now dead, amongst the educated classes. They know that its powers are limited and its weakness and inconsequence and untrustworthiness great. But they cannot afford to forego the use of imperfect faculties, else they would use none. For reason is not unique in this respect; nor has the reason which doubts or denies another source or another structure than the reason which assents and defends: 


\section{THE CALL OF THE MODERN AGE 225}

in both cases it stands for the whole man striving to know. Truths which are above reason to question are above reason to aver; and great, indeed, were the confusion if the better reason were not to prevail ; for there is no other court for deciding between truth and error.

It is a profound ill-service to religion to refuse to bring its truths to the proof of reason. It is to carry into an emancipated age methods which could be tolerated only when men had not assumed the responsibility of their own lives. Now, the only result is to create suspicion of the deliverances of the religious consciousness, and to deprive it of the most powerful of all support, namely that which it would derive from evincing before an impartial tribunal, the soundness of its principles and the rational coherence of its contents. Besides, what is the difference between religion and superstition, except that the former invites and the latter evades enquiry; that the former claims to gain in convincing power as the experience of humanity grows and its wisdom ripens, while the dominion of the latter becomes less secure 


\section{IDEALISM AS A PRACTICAL CREED}

and more confined-its phenomena being ex hypothesi outwith the laws of experience?

Such, I believe, is the attitude of the better mind of the day towards religion. It demands that religion should sustain enquiry.

And the enquiry can not be postponed. In every department of man's experience there emerges an interregnum between the overthrow of a dogmatic or external authority and the safe enthronement of a new and free authority within. In the region of the moral, the social, or political life, emancipation from outer law is apt to be followed first by the chaos of caprice-which is the freedom of the rudimentary will. In the province of theory dogmatic authority is followed by doubt and disbelief. The religion of authority when it is expelled naturally leaves behind it a kingless realm, for the first effect of criticism is to destroy ; and the most destructive criticism of all is that which a wider and maturer experience passes upon a narrower and more crude. Creeds can survive the exposure of logical incoherencies; for men believe many things which they know not how to reconcile. 


\section{THE CALL OF THE MODERN AGE 227}

But when the experience which they are meant to define and express outgrows them, their doom is pronounced. They become dead hypotheses, and fall away, like withered ivy, from the life to which they cling. Men do not concern themselves even to refute them, any more than they refute the opinions of the days of their childhood.

I am unable to resist the conviction that in these days the religious and ethical experience of reflective men has thus outgrown the definite creeds. I do not say that it has outgrown the deeper principles which the creeds were meant to express: I believe these are immortal. But the expression of them which satisfied other ages, different in their outlook and in their very temperament, has in our day become inadequate even to untruth. There are men 'whose very life is in religious ideas,' but they know no expression of these ideas which does not render them suspect, or even illusory. 'They, therefore, dwell, as it were, in a world of eclipse and paralysis, neither able to find a faith nor to do without one, sitting 


\section{IDEALISM AS A PRAC'IICAL CREED}

'By the poisoned stream of life,

Waiting for the morrow that shall free them from the strife.' 1

That their despair is the product of their own growth they have not discovered; nor that the experience which condemns the creeds contains the elements, were they but comprehended, of a better faith.

These are the men whose demand for a more adequate philosophy of life are altogether legitimate. In so far as Idealism professes to furnish such a philosophy they have a complete right to ask that it shall prove its averments. Their demand is in all respects the same as the demand which our times make for more adequate principles in the light of which its social phenomena may be interpreted-unless indeed their demand be still deeper. It is the demand of a life which is richer and more free for a wider and better articulated faith in which to dwell at peace. And it can be met only in the way of freedom : not by the methods of dogmatism any more, but by those of proof, if such a method be 1'The Problem of Philosophy at the Present Time': Caird's Essays on Literature. MacLehose, Glasgow. 


\section{THE CALL OF THE MODERN AGE 229}

possible: if it be not, then, at least, by the method of rational probability. For only in this way can their life be again made coherent, and only the synthesis of reason can reconcile.

But is such proof, or is such rational probability attainable? This is the question which the Idealist has to meet. His opportunity has come; the conditions he requires are to his hand; can he rise to the demand? 


\section{VII.}

\section{THE ANSWER OF IDEALISM.}

THE collisions within modern experience: Idealism has deepened the problems of modern life: Hybrid theories which would avoid ultimate issues, and why they must fail : Man at his best only when in touch with ultimate issues: That the opposites of experience are correlates: What follows-is it Pessimism and Scepticism, or Optimism and Idealism? How opposition implies unity, and the actual implies the ideal; and how Pessimism and Scepticism play fast and loose with their own premisses : The only true inference is that the ideal is real and the real ideal, and that it is Man and not God which is in the Making: The bearing of this view on man's freedom: Why is life a process never completed, and whether optimism stultifies morality: The one circumstance which would destroy Idealism and Optimism; but there is no evidence that it exists: The hypothesis of Idealism is the sanest yet discovered, and is well worth subjecting to the strain of a nation's practice. 


\section{LECTURE VII.}

\section{THE ANSWER OF IDEALISM.}

THE spiritual synthesis of modern poetry and philosophy can have little meaning except to men who have, at least to some extent, sounded the depths of the discrepancies of experience. But the variety and magnitude of the interests of modern life and their violent collisions; the change in the structure of society which is one of the consequences of the organization of men in pursuit of these inconsistent interests; the demand which the change makes for a more adequate intellectual, moral and political response if the new circumstances are to be comprehended and controlled; the emancipation of men's minds from the bonds of dogmatic authority, whether sacred or secular, and the obsolescence of the religious and political creeds, have co-operated 


\section{IDEALISM AS A PRAC'TICAL CREED}

together to make the discrepancies of experience undeniably evident to all reflective men. There is, probably, no need of the time so deep or so imperative as the need of surer guidance amongst the problems of the social and religious life.

No doubt the ultimate principles on which man's welfare rests are permanent; and in this respect 'there are no discoveries in morality.' But although there is no need of a change of principles, principles change ; like living things, they preserve their permanence through constant reconstruction. Every application of principles to new circumstances elicits some new feature of their meaning. Their adaptation is their reinterpretation. But this is a difficult process. And if the change of circumstance is great, there ordinarily ensues an interval between the failure of the ancient and the establishment of the new moral and mental habitudes during which all is in flux and uncertainty. The ancient rubrics fail and there are none to take their place; the positive and continuous life which moves from the one form to the other is undiscerned, and men do not comprehend the tendencies which 
they obey; or, in other words, 'they do not understand their times.' At such periods the best which men possess wherewith to meet the future are vague aspirations for a good whose features they cannot clearly see. They yearn for they know not what, and their thoughts are like homeless winds, with moaning in their music. The issues amongst which they live are vast and hidden in great darkness. Such a period is ours. Grave questions are being gravely asked; and the answers do not satisfy. The conditions which demand constructive dealing with the social and moral and religious life are present, and the opportunity of Idealism has come.

These were the conclusions at which we arrived in the last lecture. We have now to ascertain whether the synthesis which Idealism offers is trustworthy.

The first and most palpable effect of Idealism has been to aggravate the difficulties which it professes to remove, and which were implacable enough already. Its attempts at synthesis have shown how intractable the contradictions of ex- 


\section{IDEALISM AS A PRACTICAL CREED}

perience are ; its assertion of the unity and of the spiritual nature of the world has accentuated the incoherencies of life. There is not one spiritual problem, whether in morality, or in social life, or in religious faith, which it has not deepened. A brief contrast between the present age and its predecessor will make this evident.

A little while ago the realm of nature was hardly recognized as a coherent whole. The physical sciences were feeble, they worked apart, their provinces did not intersect. Physical life stood, apparently, unrelated to its material substrate: it was taken as a clear addition to it. Within the domain of physical life itself there were fixed species, each of them describable by itself: the problem of their connexion was not raised. Man as a rational and responsible being stood aloof from all-an exception and addendum to the natural scheme. Even his own nature was riven in two: his body was merely the temporary tenement of his soul. On all sides there were interstices, and rifts, and opportunities for miraculous interventions-which came. For, beyond the natural world and 
around it, ready to flow in upon it at any moment, there was another. It was the object of faith rather than knowledge, of spiritual rather than natural vision; it was dogmatically asserted on the one side and meekly accepted upon the other. God dwelt in that remote region of moveless mystery, in sovereign majesty inscrutable; 'He made darkness his secret place; his pavilion round about were dark waters and thick clouds of the skies.' But of intrinsic or rational continuity between that world and this, there was none; and experience here gave little clue to experience there: for was not experience in this world merely natural, and spiritual experience assumed to be mere mystery? The scheme was in one sense simple; its elements were conceived in terms of the imagination, they were peacefully ranged side by side, and the problem of their coherence was not raised. There was the superintendence of a sovereign will whose ways could neither be questioned nor comprehended: and that sufficed, for the demands which men made upon their deity were not deep. They did not ask for spiritual intimacy, 


\section{IDEALISM AS A PRACTICAL CREED}

and they were not unwilling to bow the soul in worship before power inscrutable; for the spirit of religion was not free.

Under these conditions, the principles of man's spiritual life were easily maintained. He was free because his soul was detached from the natural order. He was responsible, because he was subject to a sovereign will. He worshipped, for he was weak in the presence of Power and filled with awe in the presence of mysterious majesty. It was not recognized that the freedom of detachment is the freedom of caprice and helplessness; and 'awe,' which has nothing religious in it, was confused with ' reverence.' And so long as the only function of society was to let man be, or to 'interfere' only to protect his exclusive rights, the laws of social life were intelligible and the path of the legislator plain. In all of these regions of man's life there were higher agencies at work than he recognized in his theories. His actual freedom was not merely capricious; his obedience to duty was not merely servile; trust and love mingled with his awe; and social filaments so 


\section{THE ANSWER OF IDEALISM}

bound him to his neighbours that his egoism was frustrated and rebuked on every hand. Still the last theoretic word as to nature was, not unity but difference; as to freedom was detachment and caprice; as to society was the individualistic independence of those who were aggregated within it; and as to God was a sovereign will, which dealt with nature, and saved or reprobated men according to His own ' good pleasure.'

Now all is changed, for the spirit of man is changed-changed much more profoundly than his circumstances and the conditions of his outer life upon which we are prone to fix our gaze; for these latter issue from the former even while they react upon them. Belief in the unity of the natural universe, including man, is now practically universal in civilized communities. There are neither interstices nor rifts; there are no causes without natural consequences, and no effects without natural and necessary antecedents-no mere accidents anywhere. The whole scheme is compact, and man is a part of it. His psychical nature is inextricably inter- 


\section{IDEALISM AS A PRACTICAL CREED}

twined with his bodily frame; he is not spirit plus soul, plus body; but spirit, soul and body interfused; a sensuous-rational being, continuous with the world in which he lives. All being is of one tissue. What, then, of man's moral nature and the freedom which it implies? The freedom of detachment is no longer possible, for there is no detachment. Where all things fall into one scheme, and are by their very nature compacted together in one indiscerptible whole, the whole appears to be the only agent, and no action can be attributed to the parts and elements except as instruments of that whole. The plant lives and grows because the whole world with its circling seasons at once conspires to help and fails to frustrate it. Of separate action of its own, of action which is not interaction but isolated and genuinely originative, there is none. And in his isolation is man anything better: or does not he not sink into a mere name for that which can not for a moment be? The problem of his freedom has become more difficult. Nay, it is insoluble, except at the cost of reinterpreting both man and his environment. 
And once we recognize the unity of the natural universe and regard it as a closed system, what becomes of that world beyond upon which men had fixed their better hopes? By what apertures can its influences flow into a system which is all compact? "The ranks of science have closed' and the supernatural has been shut outside. It has become an empty and impotent region. No God dwells therein who can be known of man. Nor can he miraculously intervene to help except by some suspension or change of the whole scheme. The Deism, which witnessed to a God benevolent but remote, has no defence whatsoever against the Agnosticism which dares not affirm and the Scepticism which must deny. Belief in such a God has perished of inanition, which is the most complete of all refutations. But what other God is possible? Once more the alternatives are those of complete negation or a new interpretation.

When we contemplate man, not merely as a part of a natural scheme but as a moral and religious being, the difficulties deepen further. There is a sense in which man's destiny as a 


\section{IDEALISM AS A PRACTICAL CREED}

spiritual agent has always seemed hard and incongruous. $\mathrm{He}$ is a victim of time inflicted, and yet glorified, with aspirations which are more than temporal. His ends are beyond his achievements, his purposes exceed his means, and failure is written on every page of his history to the last line. Such is his record at the best: he cannot count that he has 'attained.' At the worst his life is mean, and sinful, and wretched and very brief-his better purposes abandoned, his aspirations stifled and the light of his soul well-nigh gone out. But the situation was not intolerable under the ancient scheme. God might interfere and obtrude upon man's sin and misery the sovereign hand of mercy, and by a miraculous gift of grace, all undeserved and without leverage in man himself, lift him above it all. The thoughts of men were satisfied even though that grace was not given to all. For was not the sovereign will benevolent in that it gave to many, and did not justice deal with what remained? The artificial scheme was fit to cope with the artificial circumstances. 


\section{THE ANSWER OF IDEALISM}

Now it is all obsolete: we reject both the scheme and the situation which it was meant to meet. Man's view of his own nature has changed. $\mathrm{He}$ is not vile by constitution, but by the violation and distortion of it; and the ideals which he never fully attains are nevertheless the operative powers of his life and his most essential being. His sense of brotherhood has been widened, and his consciousness of the solidarity of his kind; and his yearning now is for the race. Moralized himself, he moralizes the object of his adoration. The sovereign will which knows no law save its own caprice is not divine. Love is paramount, and justice is its instrument. The 'Moral Governor' has become 'Our Father,' and His destiny is one with our own. Our final failure were His failure. Miraculous interference has been transmuted into a constant law; for God dwells in man, a Presence which never fails, a free Ideal always operative.

But if we thus identify the destiny of man with God's and make 'our salvation sure,' is not the converse also true? The evils of the world and the sinfulness of man are real: does God, 


\section{IDEALISM AS A PRACTICAL CREED}

then, manifest Himself in these? If $\mathrm{He}$ is at the heart of man's volition when man does the right, is $\mathrm{He}$ absent when man sins? The doctrine of the immanence of God and of the universality of his all-loving will has shed a broader and more generous light upon man's fate; but the difficulties which it brings are all too obvious. The evils of the world thrown upon such a background cast a deeper shadow: for God participates therein. We find thoughtful men in these days, resolved to face facts rather than to obscure their vision with pious insincerities, refuse to admit that the Being who manifests Himself in this misery-stricken world and in the sin-stained life of man can be all-powerful and all-benevolent too. They limit Him: He is tainted with the finitude in which $\mathrm{He}$ dwells. 'The Moral Governor,' the 'Sovereign Will' that out of its own good pleasure called the universe into being and then let it go, sat aloof and was not contaminated; but we speak of a 'Presence deeply interfused'; and are, as it seems to many, constrained to choose between the testimony of the moral consciousness to the reality of the 
difference between good and evil, and the testimony of the religious consciousness to the perfection of the God in whom it would find rest. The conceptions of the Idealist have served to make the contradictions of man's experience hold up a more intractable front.

The same cause, bringing similar results, is seen to be operative when we consider our present attitude towards the history of mankind. A little while ago, good men-men of learning and reflexion, of deep piety and sincere human sympathy, entertained without dissent or recoil the conception of the partial rule of a beneficent providence in human history. They could tolerate the notion that there was one small people elect, living on the shores of the Mediterranean Sea, whose history alone was sacred, and who were the object of divine care and love. All the other nations of the world were beyond His ken-or worse, they were objects of His undying wrath. The belief is obsolete. It serves now but to illustrate the tyrannic power of theological schemes, and to show how slowly men arrive at a universal love of their kind, and how surely 


\section{IDEALISM AS A PRACTICAL CREED}

are their own defects reflected in the God they worship.

By a process unmarked, like the circling of the wintry earth towards the spring, we find ourselves in a more genial spiritual atmosphere. We know now, or at least we ought to know decisively, that such conceptions of God are unworthy of Him and of ourselves. All history is sacred, the object of a love that is not limited nor partial and of a care which is not intermittent-or none of it is sacred. God is everywhere, sustaining by His Holy will and unfailing loving-kindness the tottering footsteps of all mankind in its toilsome ascent towards its native spiritual altitude,-or $\mathrm{He}$ is no-where, and there is no God. But how, we ask, with deeper and much more tragic doubt, can we find Him everywhere? What kind of faith can sustain the appallingly pathetic scene which history presents -of men all on their way to the long silence and yet at strife, strenuously urgent on idle ends; strife without limit except for their little means, without break except for the brittle brevity of their lives, and often without mercy; strife for 
that which does not satisfy and whose attainment is not seldom mere loss?

It is not possible to survey these phenomena and still ask whether doubt has deepened : nor is it possible to be oblivious of the cause. The deepened doubt is the natural consequence of our spiritual growth. It is a law in man's affairs that new triumphs shall bring new tasks. Every advance in intellectual development reveals new and greater difficulties to solve-greater problems for wider minds. Moral progress means larger responsibilities and harder duties; and every step in the broadening of sympathy brings new suffering. By uniting nature to man, man to man, and all with God Idealism has involved all that exists, or that man can conceive, in one doubtful destiny. There is no picking of footsteps any more, nor wary walking amidst the distinctions of artificial schemes: the whole web has been torn. There is no salvation now by partial issues; the question of the rectitude and sanity of the whole order of reality has been raised, and there remain but two alternatives-hope which cannot despair, or despair which cannot hope. 


\section{IDEALISM AS A PRACTICAL CREED}

I am aware that there are hybrid schemes which attempt to justify the avoidance of these ultimate issues, and I must say a word or two of them in passing. I have referred already to their characteristic method: they compromise the order of nature saying that it holds only in parts, or at least that we have no evidence for more than a partial order. They compromise the infinitude of God on similar grounds; for we have evidence neither of His omnipotence nor of His absolute goodness, but only of His striving against the evil which $\mathrm{He}$ has lacked the effective will to overcome, or to prevent from existing at all.

These theories appeal to 'common sense' and make it their prime merit to take facts as they stand, viewing them through no distorting principle, whether optimistic or pessimistic. And on the whole they are pleasing to common sense; for 'common sense' is suspicious of rigorous methods and avoids extremes. It even prides itself upon its superiority to logical necessities, as if it were a merit of experience that it should be not merely varied in content, but in- 


\section{THE ANSWER OF IDEALISM}

consequent. And common sense, making no pretension to coherence is pardonable enough, even though it plumes itself upon its chief defect. But a philosophy has no such defence ; a theory cannot take refuge behind its own incoherencies. Its appeal is to awakened reason, which assumes that where there is incongruence there is falsehood, and which must restore the order of experience. But these theories fail to satisfy reason. Their compromise amounts to nothing more than the restatement of the difficulties demanding to be solved. For they will prove to be sceptical or the reverse according as the accent is allowed to fall upon the defects of the object with which they deal-be it nature or God-or upon the criterion by reference to which the defects are exposed. These Pluralists and Pessimists have in themselves something that is superior to what they condemn-a standard by which the world is found to lack order, and God perfection.

But, further : it ought to be evident to philosophers that an objective order which holds only here and there implies principles which are true 


\section{IDEALISM AS A PRACTICAL CREED}

only now and then. But such principles are as impossible in ethics or physics as they are in mathematics. There are facts whose law we have not been able to discover; but to say that there are facts to which no law applies is to say that there are facts which have no nature of their own ; for the nature of a thing is its law. To deny or to doubt the universality of law is therefore to deny or to doubt whether a thing is always itself; and to deny or to doubt the order of reality as a whole is to dissolve the objects of which the order consists, and to leave nothing the same with itself.

Not less evident is it that a God who is not infinite but limited is a God who is neither self-subsistent nor self-determined. If he acts it is only under conditions which he has not called for, and he operates upon an environment over which he has not complete control. $\mathrm{He}$ owes his being to the causation of a prior and presumably a higher power. Manifestly, therefore, the name 'God,' which is just our name for what we deem to be in itself all in all, must be transferred to that higher power, or to some 
whole which is self-sustained and self-determined. And these theories succumb to this necessity. There is an absolute above their God; or a companionship of spirits which is greater than himself, and of which he is an important member, and nothing more.

Such methods of compromise, which apply principles only up to a certain point and then stop short, are not able to stand the strain of man's awakened thought. Science demands categorically that a law shall apply universally to the matter to which it is relevant-and, of course, that it should hold of other matter is absurd. Philosophy has no function, nay, it is aware that the mind of man can not act, except on the supposition that the nature of things must be constant-whether that nature be static or in flux, and that they cannot be other than themselves. Theories to which the order of the universe is tentative, transfer the defects of man's knowledge to its object, destroying both. Those which maintain that the order is only in the making-God and man striving with limited though unequal powers to bring that order about 


\section{IDEALISM AS A PRAC'TICAL CREED}

-look for an issue for which they deny a cause : for the order is said to be in the making, while there is neither in God nor in man aught adequate to make it. Theories which isolate objects from one another and set up a pluralism, must either deny the need of connexions, or admit that they are at once necessary for knowledge and fictitious-fabrications of the mind, which mind knows to be fabrications and still employs. But 'Falsehood, be thou my Truth!' like 'Evil, be thou my Good!' is a maxim for the phantom ruler of the phantom realm of chaos. And 'conceptions which are valid but not true' are amongst the oddest inventions of philosophers in distress.

Not by such halting means as these can the problems of the modern spirit be solved. Men in earnest with thought, like men in earnest with life, are thrown back upon absolute alternatives. Their instances are crucial. They test their colligating hypotheses by them, and the failure of these hypotheses is the dissolution of their world, the loosening of the bonds of its rational order, and the destruction of all its parts. 
Nor is it in the province of theory only that men try the very fibre of reality by individual instances. We see the test applied sometimes by very humble minds which make pretence to no philosophy. Let tragedy come in its power to any man, and he will ask ultimate questions. Bereaved by death of the object of their supremest love, foiled of the purpose that gave value to their lives, or conscious of the deep stain of some ill-deed repented of but now beyond recall, and working out in the lives of others its fell consequences, and finding no healing for their woe, men despair of more than themselves. They despair of the whole extent of being; they disbelieve in God. The ultimate alternatives arise in their souls, and they say: "Either this evil does not stand final and irremediable, but will yet be over-taken and over-come, or the whole scheme of things is evil ': either 'God's in His heaven,' or there is only Destiny, which has neither a heart to pity nor eyes to see : either 'the world is no blot nor blunder, but means intensely and means good,' or it is 'Void of Life, of Purpose, of Volition, even of Hostility: 


\section{IDEALISM AS A PRAC'TICAL CREED}

one huge, dead, immeasurable Steam-Engine, rolling on, in its dead indifference to grind me limb from limb.' 1

'A hasty generalization,' the man at ease will say; 'the shadow of a disappointed ego cast across the broad universe; the whole world condemned because it will not butter our bread.' 'A valid generalization all the same,' I would answer. Under the conditions stated no other is possible. The nature of things is evinced in every one of its elements, and the fate of the whole is at stake in all its particulars. There is only one proviso, namely, that the instances shall be genuinely crucial. What, then, makes an instance crucial? Simply that it is relevant to the general law or that its nature is known. And it is just the feature of these superlatives of thought and emotion that their instances are postulated as crucial. When man is tried to the uttermost the ultimate hypotheses upon which his life rests are in question. They are his ideals, without which his life would have neither meaning nor value. And the validity ${ }^{1}$ Sartor Resartus, 'The Everlasting No.' 
of his ideals implicate his world. For the soul of man, however buffeted and foiled, is bent upon perfection, and he can tolerate nothing less in his ideals which express that perfection. So long as he retains his ideals the worst has not come: but when they fail his powers collapse, for he has neither standing place nor fulcrum. His whole universe is a bottomless quagmire and there is no safe footing anywhere.

Man is never at his best or highest except when he is in touch with ultimate issues. The scope of earnest doubt and of earnest faith are coextensive. And there is perhaps no surer evidence of the value of the Idealism of these days - whether we consider the implied Idealism of the sciences, the imaginative Idealism of the poets, the Idealism of faith which religion brings or of assured knowledge which philosophy seeks - than that it has contributed to bring us to confront these issues. The very postulates of our life are now upon their trial : of knowledge, because the alternatives are the order and the rationality, or the disorder and irrationality of 


\section{IDEALISM AS A PRACTICAL CREED}

the world, which is its object; of morality, because they are the possibility or the impossibility of human freedom; of religion, because they are the existence and the immanence, or the non-existence of God. Adapting the words of Carlyle to our age, we may say that 'The Everlasting No has pealed through all the recesses of its spirit.' The compromises of the ancient creeds avail no more.

But it is often assumed that in these ultimate matters of universal denial or universal affirmation in knowledge, of freedom or necessity in the sphere of morals, and of faith or unbelief in that of religion, the choice is a matter of temperament and not of reason. Set between these opposite poles, the mind of man, we are told, is helpless; because both alike lie beyond our experience, and, indeed, are nothing more than fictions of abstract thought. What experience yields always and to all men is neither absolute law nor the utter absence of it; neither unlimited freedom nor universal necessity; neither complete knowledge nor utter ignorance; and in religion, at the best, 


\section{THE ANSWER OF IDEALISM}

'We stretch lame hands of faith, and grope, And gather dust and chaff, and call To what we feel is Lord of all, And faintly trust the larger hope.'

It is true that we may cull either the white or the black in this grey world of ours. We may insist on the discontinuity of things, the contingency of events and their apparent lawlessness; upon the errors and limitations of our intelligence; and upon the wrongs and suffering of the world-for they are all real. Then Scepticism and Pessimism ensue. On the other hand we may fix our attention on the evidences of order and law, on the triumphs of the intelligence, on the joys of life and on our wider outlook. Then religious and moral faith ensue and the Optimism which they imply. But we actually experience none of these pure qualities; and all of them alike are incompatible with our real life, in which knowledge is contending with ignorance, freedom with necessity, good with evil, and faith with doubt. And man in all his thinking must sustain himself upon experience; for beyond experience is the realm of the imaginary, where all affirmations and 


\section{IDEALISM AS A PRACTICAL CREED}

negations have equal value, and therefore none at all.

Besides, these opposites are correlative, and they exist only in and through their mutual reference. Knowledge implies ignorance, for truth is concord with reality and therefore implies their difference. Morality implies a distinction between 'what is' and 'what ought to be'; for it is a process of raising the former into harmony with the latter, of making the actual ideal, or the ideal actual. If they coincided morality would have no place or function. Hence good implies evil, and cannot exist apart from its possibility. In a similar way the finite and dependent and necessitated both implies and is implied by the infinite, the self-determined and the free. And Nature and Spirit are correlates; for the sphere of Nature, however imperfectly known, is still the object with which knowledge strives, and Spirit without its object would be inert.

Both of these objections are held to paralyse Idealism, and every other form of Monism that would make all things of one tissue. You must 
pardon me if in dealing with these objections I must try your patience for a little; for they are evidently vital and they are much in vogue.

I wish to admit the objections so far as to give our opponents the full benefit of them. But I would hold them to their objections, and by doing so, I believe, show that the despairing conclusions which they draw from them are erroneous.

First, then, as to the contention that we have no experience of absolute knowledge, or absolute ignorance; of absolute good or absolute evil; but that all we know and all we do is imperfect: never the pure beam, but a mixture of shine and shade. I grant that we have no experience of them. I grant also, nay I insist, that where experience gives no guidance reason is helpless. Indeed, reason is nothing but organized experience seeking truth. Not being objects of our experience, we must conclude that these pure contrasts are fictions, products of an imagination which first abstracts, and then gives a false reality to its abstractions. It follows that we must simply set them aside, and refuse to deal 


\section{IDEALISM AS A PRACTICAL CREED}

with them: just as a mathematician would refuse to deal with an imaginary region where twice two makes ninety-one, or where all the triangles are circles. But it follows further-and this our critics have not observed-that it is no defect of reason not to be able to deal with such recognized fictions; and that its failure to give a rational preference to one fiction over another can not be made a charge against reason. We should not applaud the reason of the mathematician who preferred a geometry in which all circles are squares to a geometry in which all circles are triangles. Between fictions there can be no rational choice. Idealism is concerned vitally in showing that we learn through error, and find 'through evil that good is best'; but it is not concerned with what would take place in an imaginary realm where knowledge and goodness have no possible opposites. It abides by experience, and demands from reason no irrational choice.

Secondly as to the vital correlation of the opposites that fall within experience. We are told that they cannot be except in their contrast, 
for each term implies its opposite. Be it so! I accept the objection, but, I insist once more that they who make it shall abide by it. As these opposites cannot exist except in mutual reference, seeing that when severed they become fictitious unrealities and that they are presented to us in all our experience only in their correlation; then let us deal with them in their correlation. But this means that we shall deal neither with the one nor with the other, but with their unity. We deal, in other words, with what transcends their opposition; nay, with that which in our own experience transcends their opposition-for, we are told, we experience naught else. But, what becomes, then, of that ultimate failure which obstructs God, and that irremediable evil which limits His infinitude, and condemns the universe to a vain struggle that can never end? Manifestly we cannot treat the pain and wrong of the world and man's misery and $\sin$ as final, and at the same time make them relative to the good. The critics of Idealism play fast and loose with their own premisses, and according to the exigencies of the moment 


\section{IDEALISM AS A PRACTICAL CREED}

assert or deny the absolute opposition of good and evil and of all the other opposites.

Still, it may be said, the crucial difficulty of Idealism remains. If Pessimism and Scepticism are refuted through the reference of evil to good and ignorance to knowledge, and necessity to freedom, and finitude to the infinite, the opposite affirmative of Idealism and Optimism is also refuted. This objection also seems vital, and we cannot pass it by. It seems to destroy the very postulates of Idealism, and by another route to negate the order of the world and the perfection of God.

In order to deal with it let us return to the presupposition upon which it rests, namely the essential correlation of the opposites of experience, or, in other words, their existence only within a unity which includes them both. That unity must evidently be either some third thing in which the opposites are transcended: something which is beyond the contrast of science and nescience, good and evil, freedom and necessity, finite and infinite being; or, on the other hand, it must be one of these opposites themselves, which 


\section{THE ANSWER OF IDEALISM}

includes the other amongst its essential elements, or manifestations, or stages, or functions, or which presupposes it in some other way. There are Idealists who have sought escape in the first of these alternatives. They have spoken of God as 'the unity beyond the difference of subject and object'; of an absolute whose knowledge is intuitive and whose thought is creative and in which the last contrast of truth and reality disappears; of a being to whom the opposition of good and evil does not apply, for there is no contrast between 'what is' and 'ought to be' in his activities, and who has therefore no moral attributes. All the predicates of finite experience fall away; attributes of finitude meet in but are also transcended in the absolute, whom therefore we cannot conceive. The absolute is all in all : God is the sum of all perfections and in Him all differences are reconciled, but after a manner which man can not conceive. ${ }^{1}$

It would take us too far afield to endeavour to examine this view. Nor is it necessary. It is a manifest failure. A unity which in transcend-

${ }^{1}$ See Bradley's Appearance and Reality. 


\section{IDEALISM AS A PRACTICAL CREED}

ing the differences obliterates them is not their unity. A unity which becomes itself unknowable, or lies beyond the reach of all predication, holds no differences together, but sinks itself into an empty affirmation of the all-in-allness of everything. Nay, this attempt was foredoomed to failure from the first: for no third thing can ever unite. That which comes in as third is but one difference more, demanding to be itself reconciled with the other terms. What unites must be an element of community in the things united, and it must express itself in both. And, finally, in professing to explain the antagonisms of experience, this theory carries us beyond the boundaries of all possible experience. We are led into the realm of the void, where only the unbridled imagination may roam on its empty mission.

Thus there remains the second alternative: that the unity in which the opposites of experience meet is one of these opposites themselves. This view, I believe, is true. That it brings grave difficulties of its own I am well aware : and even if it is valid, it has to be verified, little by little, 
by application to the facts of man's intellectual and spiritual experience, just like any other principle.

But if certain assumptions are allowed to go unchallenged it will at once appear to be false. The first of these is the assumption that correlatives which imply each other so essentially that they cannot exist except in mutual relation must be in all respects upon a par. If $\mathrm{A}$ cannot exist without $\mathrm{B}$, nor $\mathrm{B}$ without $\mathrm{A}$, then they are equipollent. But this is not true, except in the domain of simpler existence and simpler thought. When we ascend to more complex objects, essential correlation is found to be compatible with the dominance of one of the correlates. Environment and organism, object and subject, means and purpose, are mutually implicative, but they are not upon a par. And it is possible that error and truth, evil and good, necessity and freedom, nature and spirit, the finite and infinite are in like case.

In the second place there are assumptions as regards the nature of knowledge and of morality which would destroy our hypothesis. It is 


\section{IDEALISM AS A PRAC'IICAL CREED}

assumed as to knowledge that it is a process of bringing differences into unity, of colligating phenomena in themselves separate into coherent systems, or, as we say, of applying universals to particulars, or laws to facts. No Idealism is possible on such terms. The speculations of Kant have shown that such a view cannot escape from the toils of dualism. But having accepted the objection of the critics that unity and difference, laws and facts, thought and its object cannot exist apart, and in themselves are mere abstractions, the problem of bringing them together cannot arise. To assume that such a problem can arise is to resuscitate the abstractions which have been condemned. As to morality, it is assumed, in a similar way, that it is a process of bringing 'that which is' into accord with 'that which ought to be,' or of raising the actual to the level of the ideal. And these are taken to be mere opposites and exclusives. It is the contrast of what is actual, and condemned as imperfect, with that which is only a conception, and which is called good. That is to say, what is actual is evil, and what 
is good is unreal. But morality on such terms is evidently both impossible and futile. There can be no value in converting what is real into a mere idea, for a mere idea, however noble, has less worth than the crudest thing that is actual. But this view also resuscitates the exclusive alternatives already rejected: real and ideal, good and evil, it has been agreed, have no existence apart, and are mere abstractions.

Further, the view represents both knowledge and morality as radical modifications of the order of the existing world. Knowledge is made into a process of inventing relations between facts given as isolated; that is, it stultifies itself, for by its very success it would represent the real in a way in which it does not exist. Successful knowledge results in a coherent system; but the facts it is meant to image, or to reproduce faithfully in thought, are assumed not to be members of any system. Morality is made into a process of projecting forth an ideal, and of in some way making the actual agree with it. It demands a change in the nature of what is real under the 


\section{IDEALISM AS A PRACTICAL CREED}

operation of that which is altogether alien : a change which is possible only by a miracle.

Evidently, then, we must define our contrasted terms in another way. The real which can express itself in systematic knowledge must itself be a system, and not a collection of discrete entities. The moral agent who can raise himself and his world to the condition in which they 'ought to be,' must contain the possibilities of that change within himself and find them also in his world. Thus the opposition between the actual and the ideal falls within the real: or in other words, the actual which was condemned as not in accord with what 'ought to be,' and therefore evil, contains the possibility of its own better state. ${ }^{1}$ Hence, knowledge and morality do not seek to bring a new order of existence into being. The former does not introduce system into a chaotic agglomerate of phenomena, nor does morality substitute a good universe for a bad. Knowledge, in so far as it is valid, dis-

${ }^{1}$ This implies that 'evil' is dependent on 'good,' in a way in which good is not dependent on evil: and that, in all the opposites, the positive has deeper reality than the negative, and gives it its significance. 
covers the order already existent in the world; and a moral agent, in so far as his actions are good, reveals the ideality of the world, recognizing and obeying its laws and making himself their willing instrument. In both these activities man's function is repetitive: his thoughts and his volitions, in so far as the former are valid and the latter good, acquiesce in and reproduce the objective order. He appropriates that order in his personality, making his mind the mirror of its truth and his will the instrument of its purpose. And, moreover, it is only in this process that the world appears as real and as good. Man realizes himself by means of it, and it reveals its nature by means of man.

I must dwell for a little upon this matter, for it contains the essential message of Idealism.

It means that, both in his cognitive and in his moral activities, man finds his ideals in the world. That this is true as regards knowledge is easily seen. The universe as it stands is manifestly the criterion of man's cognitive attainments. No one ever sought other knowledge than the knowledge of that which is. To seek 


\section{IDEALISM AS A PRACTICAL CREED}

false knowledge, that is, knowledge which did not accord with, or express that which is real, were absurd. Hence every effort after a rational interpretation of reality, which knowledge is, proceeds on the assumption that the reality to be interpreted is itself rational. Reason refuses to deal with what is irrational ; for instance, no mathematician will try to prove that the three angles of a triangle are together equal to three right angles, nor will a physicist seek to invent a perpetually moving machine. It is only because the world is believed to have meaning that we seek to spell out its cryptogram: were we persuaded that it has no meaning our intelligence could not occupy itself with it in any way. The scepticism which denies the objective order, or the rationality of the world, destroys the occasion for knowledge: and is, of course, inconsistent with itself. But even to the sceptic the world is the standard of truth: for he assumes that he has grounds for his assertion of its discontinuity and irrationality, and these grounds are in that world itself. Thus, whether we seek to know that which is real or despair of knowing 
it, it remains the criterion of our intellectual attainment or failure: the world $\alpha s$ it is is the ideal of knowledge, whether we deem that we can attain the ideal or not.

But to say that the world as it stands furnishes the ideal and the criterion of the moral life may well seem to be nothing better than wanton paradox: so obvious is it that the very nisus of that life is the conviction that things are not as they ought to be and must be changed. Nevertheless, I believe it can be shown that upon no other assumption is the moral life possible; and that in this respect our moral is strictly parallel with our intellestual life. As we do not create the objective world in knowing it, so we do not create the moral world by our moral action. The process of morality is a process of interpretation, of obedience, and of the appropriation of that which is, and which is deemed right or good. As we wrong the world by assuming that it awaits the systematizing activity of our intelligence in order to escape from a condition of chaotic disconnectedness; so also we wrong the world of 


\section{IDEAI.ISM AS A PRACTICAL CREED}

morality by assuming that it waits upon our activity to introduce into it a law of righteousness to which it is itself foreign. ${ }^{1}$ As in knowledge we strive to interpret and simply to accept the rational order without disturbing it by any prejudices of our own, and as all our activity consists in widening our capacities to the measure of its being - throwing open the windows of the soul ; so is it in morality. Its aspiration is also after concord with everlasting law, and its prayer is 'Thy will be done.'

Thus, in both cases it is presumed that the ideal is real, and the real ideal; and that our one mission as spiritual beings is to make this presupposition good within ourselves in actual experience. We may think meanly enough of our own acquirements : our knowledge may fail on every hand and our righteousness be 'as filthy rags'; but the goal on which our souls are set, however hopelessly, is nothing less than perfection. Indeed, our very despair is but an indication of our belief in the Truth and Good-

${ }^{1}$ This was the error exposed by Hegel in the theory of Kant, who represented the moral world merely as what 'ought to be,' and therefore as a mere conception projected into the empty sky. 


\section{THE ANSWER OF IDEALISM}

ness, which we fail to attain; and it is in their presence that we discover our littleness. At the very heart of our spiritual activities there thus remains an indomitable Optimism, which the religious consciousness calls 'trust in God.' The universe, which is the object of our rational intelligence and will, stands forth justified. Knowledge and morality imply their 'absolute,' no less than religion.

It is the ignorant and the capricious spirit that finds the universe unsatisfactory. It is the first view which represents it as shallow in meaning, poor in content, given over to accident, a mysterious object of dread and superstition, and limited in its use and beneficence. When science and philosophy come, superseding the sane for the savage outlook, they teach us better. They reveal the order of its events, the inexhaustible significance of its facts, and the unlimited serviceableness of its comprehended laws. And the education and emancipation of the will brings about the same change in our view of what is real. The world frustrates caprice; it is obdurate against selfishness; it 


\section{IDEALISM AS A PRACTICAL CREED}

will never satisfy the egoist, nor give rest to the ill-doer. $\mathrm{He}$ is hurled on from disappointment to disappointment. 'To look through the shows of things, he is led and compelled.' Before there can be peace he must accept their laws, negate his own caprice, and annihilate his greed. 'Everywhere do the shows of things oppress him, withstand him, threaten him with fearfullest destruction : only by victoriously penetrating into things themselves can he find peace and a stronghold.' 1 In understanding and accord with the objective order is all his good, for it is to him ideal. The kingdom of heaven is here; let us but open the avenues of our souls to welcome it. It is pressing upon us at each moment. The rich world of nature and of human history is offering to us the treasures of its meaning with a constant urgency. 'Day unto day uttereth speech, and night unto night sheweth knowledge; there is no speech nor language where their voice is not heard.' It is inviting our comprehension, exciting our thoughts by its changes, disturbing our indiffer-

${ }^{1}$ Sartor Resartus, 'Pause.' 
ence and stagnation by its surprises; it rewards our attainments such as they are, and punishes our follies and wrongs. What more can the environment do for spirit? It cannot break into the sanctum of its free activities without destroying it: for knowledge given and not acquired, or a moral good compelled, is a contradiction in terms. The world must wait to be comprehended and obeyed in order to yield its overflowing beneficence; and man must die to the littleness of his own egoism in order to receive it. 'Then are the mind's eyes unsealed, and its hands ungyved'; and the scheme of things, natural and spiritual, is found to be God's own witness of Himself. " $\mathrm{O}$ Nature, art not thou the "Living Garment of God"? Is it in very deed $H e$ that ever speaks through thee: that lives and loves in thee, that lives and loves in me.' 1

'Thy voice is on the rolling air;

I hear thee where the waters run;

Thou standest in the rising sun,

And in the setting thou art fair.'

Verily, it is man who is in the making, and 1 Ibid. 'The Everlasting Yea.' 


\section{IDEALISM AS A PRAC'TICAL CREED}

not the great Universe, nor his God. Philosophy, in the excess of its subjectivity and diseased selfconsciousness, has been attributing the imperfections of man to the ideals which are the objects he would know, and the laws he would serve. It has denied the order of the universe, or reduced its facts into mere phenomena, saying that they are relative to man; it forgets that they are relative to man only because man is relative to them, and subjects their permanence to his flux, and their truth and goodness to his errors and wrong-doing. In recent days, by the same confusion, philosophy, or rather ordinary opinion pretending to philosophize, has in like manner been depriving God of His beneficence and power, stultifying the very name in the process. It has overlooked the contradiction of its tenets which is discoverable in every soul that seeks the truth or pursues the good, ${ }^{1}$ and which seeks them only because it deems that they

${ }^{1}$ And what man ever sought aught else? Have you ever known any one seek knowledge which is false; or desire an object because it is not good, in some poor sense or other of the word 'good'? Can such be the motive of any action? Or does not even the soul that is in revolt and seeks death rather than life, deem revolt and death its good? 
are there, eternally real in their own right, and the very life of all its endeavours. The true and the good shine, like the sun in the high heavens, everlastingly, says Plato. Man dwelling in the cave of his own ignorance, bound in the chains of his own sensuousness, taking the shadows thrown upon the furthest walls by the artificial light of his own passions as realities, knows not that they are there and rule the seasons, begetting light and life, till unwillingly, and with many stripes, he is led up the difficult ascent into the upper and open world.

I would fain end here, with the justification of the Idealism which even our common knowledge and ordinary moral life thus furnish: for no testimony can be stronger than that which all experience proffers, or which, being false, would render experience itself impossible-even the failure of experience, no less than its success.

But I must illustrate this truth on the side of our moral life, and then indicate and deal with some of the many difficulties which critics find in the doctrine.

If knowledge, instead of presuming the reality 


\section{IDEALISM AS A PRACTICAL CREED}

of its object and its rational meaning, changed its object in the act of knowing it, as phenomenalists have maintained, it is plain that knowledge would defeat itself by its very process. If it must turn all things into appearances and falsify them by its touch, it had better not touch. The moral consciousness dissents against the same subjectivity. So far from deeming the moral world to be a thing to be made or unmade, and its laws to be instituted or abrogated at his pleasure, the moral agent regards them as standing above him in eternal majesty, issuing imperatives of duty which are categorical and claiming unconditional obedience. 'Duty' and 'moral good' have no other meaning. When man employs these conceptions, that is when he discusses moral facts, he is investing the moral world with absolute authority; for 'The Good' carries within it its own justification; it exists in its own right and solely on its own account. ${ }^{1}$ The recognition of it as good is the acknowledgment of its complete autonomy

${ }^{1}$ See the opening of Aristotle's Ethics ; or Kant's Grundlegung, and Critique of Practical Reason. 
and self-sufficiency. In obeying its behests the moral agent is aware that he is bowing to a necessity which is supreme, and whose claims upon him are absolute, capable of no compromise, and abating nothing of their demands for his weakness. Heaven and earth may pass, but not one jot or one tittle of the law. It is binding, as Kant says, on all rational beings; for it is the law of reason. Man's conception of the good may be, and is, inadequate: its contents appear only with the gradual evolution of his own ethical capacities. But at every stage it stands before him as absolute in its worth and authority, a necessity he dare not question and, in the degree to which he is moralized, does not desire to question, but to obey.

But, on the other hand, his obedience to this necessity which is absolute is free obedience; for he is obeying what he himself calls good, what he himself approves. Hence he re-enacts its behests, he reissues its laws from his own conscience, and in submitting his life to their guidance he is bowing to the dictates of his own spirit; nay he is rising to the height of his own 


\section{IDEALISM AS A PRACTICAL CREED}

most sacred desires. And this is freedom. It is freedom in every highest and fullest sense: it is freedom from inner constraint because 'duty' is recognized as good, and 'obligation' as a privilege and opportunity, and the service itself as its own great reward; it is freedom from outer constraint, because the outer law and the inner desire concur. There is nothing now to frustrate his will, for 'the Good,' which is that which exists in its own right and alone must be, is on his side. 'I will walk at liberty, for I seek thy precepts.' 'I will delight myself in thy commandments which I have loved.' 'Thy statutes have been my songs in the house of my pilgrimage.' 'In thy service is perfect freedom.'

Thus, therefore, does the moral consciousness rise above the abstract opposition of law and liberty, of necessity and freedom; for the moral life is both. It is at once obedience and autonomy; obedience that never questions nor demurs, and which is at the same time the joyous expression of the heart's own desire. In the same way the opposition between the actual and the ideal, and even the divine and the 
human is sublated. The ideal, the divine, the perfect good, is that which works in the moral . process and incites its activities. It is, in the language of religion, the operative indwelling of the Most High : necessity appearing as liberty, the divine behest as free and joyous aspiration. It is the best that the mind of man can imagine or his heart desire, and that which gives worth to all else. The good that is eternal becomes the growing motive of his life; the immortal puts on mortality; God appears in the flesh, and brings man back to Himself, freely, by perfect acquiescence and joyous participation in His ends. 'My meat and drink, is to do the will of him that sent me, and to finish his work.' Deprived of the opportunity of obedience, man is deprived of all. His ideals are his life.

But why is obedience so hard, it is often asked? Why is the ascent to truth and goodness so difficult? Why must man war with his ignorance, and his passions, suffering defeat so often and gaining, at best, such poor victories? Why are his ideals so bigh and his achievements so mean? Why the suffering, and the sin and 


\section{IDEALISM AS A PRACTICAL CREED}

the failure? Why is there process at all? Why did not the good God send man forth from his hand endowed with an intelligence which could not err, and a will that could not transgress? Why is his whole nature-his intelligence, will and desires not firmly set, and his eyes altogether open, to the good and the true?

I cannot answer these questions. Philosophy can furnish no answer, so far as I can see. But I believe I can show that to be able to provide no answer implies no defect on its part; and that it has a complete right to remain silent. There are questions which ought to be neither asked nor answered; of which these are examples. There is a 'Why' which has no meaning.

If I may illustrate I may be able to persuade you that I am not seeking merely to evade a difficulty. The mathematician does not ask 'Why one plus one makes two'; nor 'Why parallels never meet.' The physicist does not ask 'Why bodies attract inversely as the square of their distance'; or 'Why the planets move'; or 'Why there is energy or space.' Nor does the Botanist ask 'Why there are plants'; or 'Why plants 
grow and die.' They ask 'How,' not 'Why.' They seek to understand that which is; not to know 'why' that which is exists. Their task is not to go behind experience but to comprehend what experience provides. And, dealing with man's nature, intellectual or moral, the law of procedure is the same. We take his nature as it is presented to us, and we observe its activities. For knowledge is the comprehension of what exists, and not of that which possibly might be, but is not.

In the next place, such questions as these are in themselves irrational and self-contradictory. When we ask why a thing is, or why an event happens, we can reasonably desire only one answer: namely, the knowledge of that within experience which has produced the thing or brought the event about. We seek in experience for the grounds of that which we desire to explain. We endeavour to find a place for the object in the system of reality as we know it. But these questions as to a human nature which we know does not exist demand that we should find in experience reasons for that which, $e x$ 


\section{IDEALISM AS A PRACTICAL CREED}

hypothesi, is not a part of experience. In short, they deal with objects which belong to the realm of mere imagination, within which, as we have already seen, all affirmations and negations have the same value, and therefore have no value at all.

Hence, such demands can furnish no grounds for bewailing the limitations of human reason; or for bowing the spirit in that awe which is not reverence, before the mysterious ways of an unrecognizable providence. It is not the refusal, but the attempt to answer such questions as these, which would prove the limitations of reason; for reason cannot be required to find within experience the grounds of those things which are not within experience. What is real must contain the conditions of that which is possible and of that which is necessary, as well as of that which exists ; and it fixes their limits. We cannot pass judgment upon the whole of things except in its own light. The whole is its own criterion; and to appraise it by reference to the possible which is impossible, because it has no ground or root in that which is actual, is 
an absurd procedure. There is no criterion for knowledge save in the real, and there is need of none. To comprehend it were to comprehend all. Hence we can set these questions aside: they arise from confusion of mind.

'Still,' it may be legitimately answered, 'the errors and sufferings and failure of man remain ; and you postulate the immanence in all things of a divine will, perfect in every might and goodness. How can this be? We admit that the life of man expresses his nature as he attempts to know the truth and to do the right, and that he always seeks real truth and goodness, and in that sense is set upon perfection; but he does not achieve. At the best his life is only a process towards the true and the good; and process is the last word of his history. Is not the permanent infected by the incompleted process; perfection by the imperfect; the eternal good by the persistent evil; God by the unhappiness and sinfulness of the world? Hence, your Idealism cannot hold. Nay, it is inconsistent with the spiritual achievement which it prizes as the best. For if "God 


\section{IDEALISM AS A PRACTICAL CREED}

is in His heaven and all's right with the world," why need we strive or cry. We may go to sleep. The moral process is unnecessary, and the moral struggle is absurd. There is nothing to struggle against except the shadows of our own errors, and the delusions of our own minds, which, refusing or ignoring the optimistic faith you urge, falsely deem that the evils are real. There is no worse enemy to morality than Optimism; for it stultifies all effort. If what ought to be "already is," it is evident that there can be no duties, and no aspirations, and nothing in need of change.

Surely such a doctrine as this is nothing better than a foul opiate which drugs man's spirit, filling his mind during 'sin's drunken slumber' with foolish dreams, and making him insensitive to the woes of the world in which he lives, and to the whole tragedy that never ceases to display its horrors around him. The poisoned cup ought to be struck from his lips.

This argument is much in vogue, and its logic looks good. But let us test it.

First, reasonable as the consequences attri- 


\section{THE ANSWER OF IDEALISM}

buted to moral and religious optimism seem to be, experience does not support the deduction. I have never known any man whose faith in the ultimate victory of right over wrong, or whose trust in God was great, lose ardour in the moral struggle on their account, or become indifferent to the suffering and sin of mankind. A Pantheism which, in raising all things to the level of the highest, degrades all things to the level of the lowest, or which represents finite being as false appearance and temporary show may have that effect. But such a Pantheism is pessimistic at the heart: it is Nihilism, for even its God is without meaning. Christian faith has no such effects. You will find St. Paul issue a challenge 'to tribulation and distress, and persecution, and famine, and nakedness, and peril, and sword' and death, and pronounce that 'in all these things he was more than conqueror through him that loved him'; and his ardour in the moral struggle was not lowered thereby, nor his deep yearning for the salvation of the sinful world. And the latest of our great prophets shows the same inconsequence-if inconsequence it be. When he 


\section{IDEALISM AS A PRACTICAL CREED}

arrives at the 'Everlasting Yea,' and not before, we find him turn to his kind with 'infinite Pity, infinite Love.' 'Poor, wandering, wayward man! Art thou tried, and beaten with stripes, even as I am? Ever, whether thou bear the royal mantle or the beggar's gabardine, art thou not so weary, so heavy-laden : and thy Bed of Rest is but a Grave. O my Brother, my Brother! Why cannot I shelter thee in my bosom, and wipe all tears from thy eyes?' 1 'The greatest optimist the world ever saw was The Man of Sorrows.' And what true follower of his was not 'acquainted with grief,' or stood not long in the 'Sanctuary of Sorrow'? These are they who identify the fate of their erring fellows with their own, and strive for their good as for their own life: and in this consists their goodness. Verily, it is not upon them that the evil of the world sits lightly. They are 'wounded for our transgressions, bruised for our iniquities, the chastisement of our peace is upon them.' They recognize the splendour of man's nature, and how it is marred by ignorance and ill-doing.

${ }^{1}$ Sartor Resartus, 'Everlasting Yea.' 
The shadows are deep because they are thrown upon the background of a great faith: faith in man's nature, faith in the Universe which encompasses man round about, faith in the God who manifests Himself in both. What idle tale is this that moral and religious Optimism brings callousness towards evil and indifference to all good!

There is, indeed, an optimism, if it deserves the name, which brings that consequence; but that is the unspiritual optimism of the satisfied animal. That optimism, however, is not in question here; our discussion is on another plane. For to the animal nature there is no sin, nor suffering save its own, nor pity for marred possibilities. It nestles in unconsciousness, and knows nothing of the tragedy that storms over-head in the world of moral right and wrong into which it has no outlook. But the critics of Idealism have overlooked the distinction, and employ the categories of natural upon spiritual things. Do the windows of their souls stand in need of being cleaned?

Moral and religious optimism, nay even pes$\mathbf{T}$ 


\section{IDEALISM AS A PRAC'TICAL CREED}

simism, begins on another level. Religious faith in God, moral trust and joy in the good imply a negation and a devotion, even a death unto life, which is the struggle and the victory. The process, which from the merely natural point of view is unnecessary and from the hedonistic point of view is bad because it brings sympathy and pain in the suffering of others, is from the moral point of view the Supreme Good. Wherever the tragedy lies, it does not lie in the moral process, slow, and painful and costly as it is, even the bearing of the cross on the way to the death of the self, which is the hardest death of all to meet. The process is even better than any having attained, which we can experience; for to him who thinks that he has attained there is no further knowing the true, or doing of the good. But the good man does not desire to be out of the service and to stand with idle hands. He does not pray that evil may be forever, in order to give him an opportunity for moral heroism; but he does look to 'a growing splendour ever on before,' which converts every attainment into the stepping stone of a dead self, and which becomes 
evil only if not made into a stepping stone. For fixed categories where ideals of a knowledge that is true and of a goodness that is good, and in that sense absolute, and are yet being gradually realized, are as much out of place as 'natural' categories. Speaking of morality or of things spiritual we must not forget their qualities. Setting aside such non-moral presuppositions, we shall not deem it necessary to pity those who are on this pilgrimage, even though the way is long, and they are often footsore and heavy-laden. There is an alchemy in moral goodness which turns even the sufferings of those who suffer for its sake into a great joy. And if there be any who would have the joy without the suffering, the sympathy and pity, and love without the woes, I can only say that they have learnt neither the meaning of these things nor their use ; and are once more forgetting the conditions of the moral life and wandering into the realm of the unreal.

But there are men, you urge, who are not on this pilgrimage. They are not 'learning through evil that good is best'; but hardening unto 


\section{IDEALISM AS A PRACTICAL CREED}

crime, and descending even deeper into aged vice. Well! are there? Are you veritably able to judge, or had we not better, both sides alike, abide the issue? For, possibly, the end is not yet. I am not persuaded that we are competent to pass final judgment upon our fellows, even in this world; or have a right to say even of the worst that 'the lamp of his soul is going out.' And beyond this life there is "The Grand Perhaps.' Browning, who had his own title to conjecture and was not without his insight in these matters, dreams otherwise of the chief of his array of sin-stained, unrepentant souls. The 'Pope' is condemning Guido to death on the morrow, and these are his musings :

'For the main criminal I have no hope

Except in such a suddenness of fate.

I stood in Naples once, a night so dark

I could have scarce conjectured there was earth Anywhere, sky or sea or world at all :

But the night's black was burst through by a blazeThunder struck blow on blow, earth groaned and bore Through her whole length of mountain visible: There lay the city thick and plain with spires, And, like a ghost disshrouded, white the sea. So may the truth be flashed out by one blow 
And Guido see, one instant, and be saved.

Else I avert my face, nor follow him

Into that sad obscure sequestered state

Where God unmakes but to remake the soul

$\mathrm{He}$ else made first in vain; which must not be.' ${ }^{1}$

Mere guesswork and conjecture, I admit; but surely not more guess-work or conjecture than the opposite view which ends all here, and makes God fail.

There is one circumstance, indeed, which would leave me with nothing to say; and, so far as I can see, destroy the hypothesis of my life. If anywhere a man can be found who seeks no good through his act or who seeks a false good because of its falsity, then the Idealist, from Plato down to this day, must hold out empty hands :

'An infant crying in the night:

An infant crying for the light:

And with no language but a cry.'

But the whole experience of mankind furnishes no such sample. Deeply as man has sinned, preferring all manner of meanness to the glorious service, that kind of preference he has never made. Evil as evil, loss as loss, a worse because

1 The Ring and the Book: 'The Pope.' 


\section{IDEALISM AS A PRACTICAL CREED}

it is worse, is not a possible motive for human action. In every act, however low, or cruel, or passionate, in every monstrous and defiant crime that has raised its head against the high heavens, the motive, if the act was conscious, that is, if the man did it, was some foolish, confused, - tragical dream of something to be gained by it. ${ }^{1}$ In speaking of man we must not forget the qualities of man; and such a man were not a man.

\section{'A monster, ... a dream,}

\section{A discord. Dragons of the prime}

That tare each other in their slime, Were mellow music match'd with him.' 2

Speaking of such a being, we are once more in the region of conjecture, beyond the bounds of experience; and neither the instance nor the criticism counts in rational argument.

But if it be true, as it seems it must, that even in the drunken sleep of sin it is some foolish dream of an impossible and misnamed good

${ }^{1}$ Browning finds Miranda's suicidal leap the best thing that remains for him.

'Mad! No; sane, I say.

Such being the conditions of his life,

Such end of life was not irrational.'

${ }^{2}$ Tennyson : In Memoriam. 
which serves as motive, then there is hope. In that case there is that in man which circumstance can foster, and feed into clearer flame: there is the love of the good if he only could recognize the good, which love can seize and use. $\mathrm{He}$ may be enlightened yet; for the conditions are present.

'Beneath the veriest ash there hides a spark Which, quickened by love's breath, may yet pervade the whole

$O$ ' the grey, and, free again, be fire; of worth the same,

Howe'er produced, for, great or little, flame is flame.' What between the marvel of man's soul within, the rational nature which cannot be put out and leave him man, and the spinning wheel of circumstance without; what between the undying need of good, the thirst that can not be slaked by evil, and the great, rich, wondrous world without to respond to it: I think that the Idealist can hold to his hypothesis. There are indeed innumerable cases in which his attempts to apply his hypothesis may fail. But in this respect his philosophy stands in like case with all the sciences; for in all of them there are 


\section{IDEALISM AS A PRACTICAL CREED}

circumstances in which the surest hypotheses can not be applied-as yet. But their application is proceeding little by little ; and the hypotheses, which are the surest knowledge that the sciences have, become surer still as they bring fact after fact within their sweep, and lodge them within the system that stands through the equilibration of its own elements. Such a hypothesis it seems to me is that of the unity and the spiritual purpose of the world-why indeed may I not call it, the hypothesis of the Nazarene teacher as to the nature of God? And I believe it is the sanest hypothesis that the mind of man has discovered as yet. ${ }^{1}$ Tried, as it ought to be tried, by all the tests which reason knows, without any longer so disastrously seeking to shelter it behind the bulwarks of authority or to defend it by any method of casuistry, tried even as we try the hypotheses of the natural sciences, it is possible that it may be found to stand. Idealism seems to do better justice to the meaning of the world

${ }^{1}$ If, as I have hinted, it is the condition of the possibility of any experience, it is more than a hypothesis : it is an absolute postulate. 
than Materialism; Spiritual Monism than Pluralism. The idea of Order 'works' better than Disorder ; of Law than Accident and Caprice ; of God than Chance and Fate. It is a hypothesis which distorts reality less; which finds reasonable room for more of its facts; which leaves over fewer incoherencies; which is less capable of being convicted of inconsistency; and which does not forget Spirit, which alone is omnipresent where truth is in question. And shall I be going beyond the facts, think you, if I venture to say that the experience of mankind is but a gradual corroboration of its truth? Man is discovering his own nature, and where his true good lies, through much failure and at a great cost; he is coming to himself through his intercourse with his fellows and the world, and interpreting them also in the process; and the one discovery which he is making, it seems to me, is that he is spirit, - a mind set on knowing, and a will fixed on Good and finding it, seek it where he will, nowhere except in the things of the spirit; that the world is means set there for the uses of his spirit, the possible content of his knowledge and 


\section{IDEALISM AS A PRACTICAL CREED}

law of his will and welfare; and that in him and it there is an ever-benevolent Presence inciting him into Freedom, whom to know and to serve is indeed happiness.

I believe the hypothesis is worthy of being tried. Looking at the confused and tumultuous and errant history of mankind, reading its meaning where I can, and seeking within it for what I would most desire to possess, or to be, or to do, I can find nothing so noble, nothing I would so willingly or gratefully make my inheritance for ever as the example of those who have made its light the guide of their faltering footsteps.

It is easy for me in closing to wish you well. I cannot forget the greatness, and the difficulties of your enterprise-a new people amidst the lonely silence of a vast continent. Material prosperity you will attain, I have no doubt; and it is worth attaining. Perhaps power amongst the nations of the world awaits you, which is also worth attaining. But a kingdom founded upon righteousness, a life amongst yourselves sanctified in all its ways by this faith in man, in the world and in God, is greater far than all 


\section{THE ANSWER OF IDEALISM 299}

these things. I can form no higher wish for you than that it may be your destiny to try by actual experiment how far this faith of the Idealists will stand the strain of a nation's practice. 
Works by Professor HENRY JONES.

\section{BROWNING}

\section{AS A PHILOSOPHICAL AND}

\section{RELIGIOUS TEACHER}

Crozen 8vo. Fifth Edition. 3s. 6d. nett

"Mr. Jones is a diligent and appreciative student of Browning, and he handles the philosophical topics suggested by his subject with firm grasp and clear insight."-Times.

\section{A Critical Account of the Philosophy of Lotze THE DOCTRINE OF THOUGHT \\ Crown 8vo. 6s. nett}

"This is a genuine contribution to philosophy. It amounts to a destructive criticism of the half-hearted attitude adopted by Lotze towards the problem of thought and reality."-Mr. Bernard Bosanquet in the Pall Mall Gazette.

\section{Social Responsibilities}

LECTURES TO BUSINESS MEN

Demy 8vo. Is. nett

GLASGOW: JAMES MACLEHOSE \& SONS PUBLISHERS TO THE UNIVERSITY

And all Booksellers 




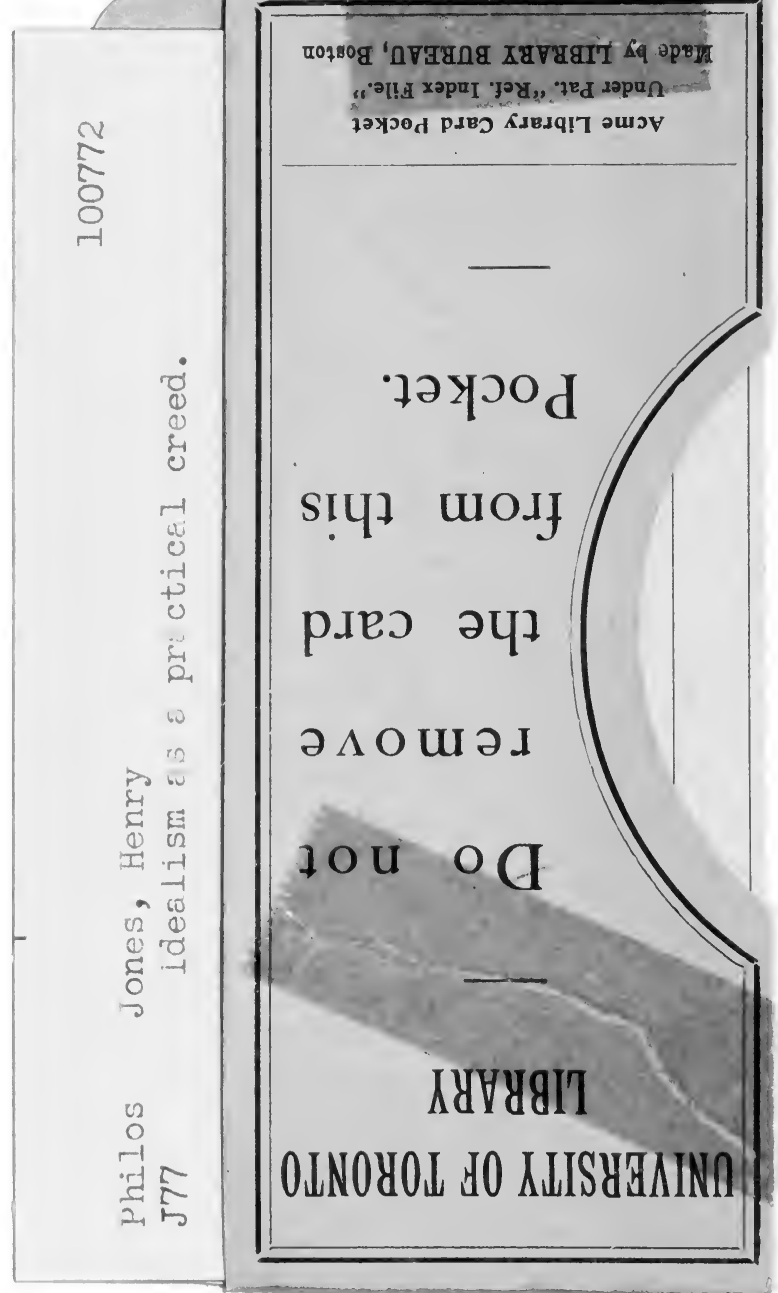


